\title{
Uncertainty Analysis of Certified Photovoltaic Measurements at the National Renewable Energy Laboratory
}

K. Emery

Technical Report NREL/TP-520-45299

August 2009
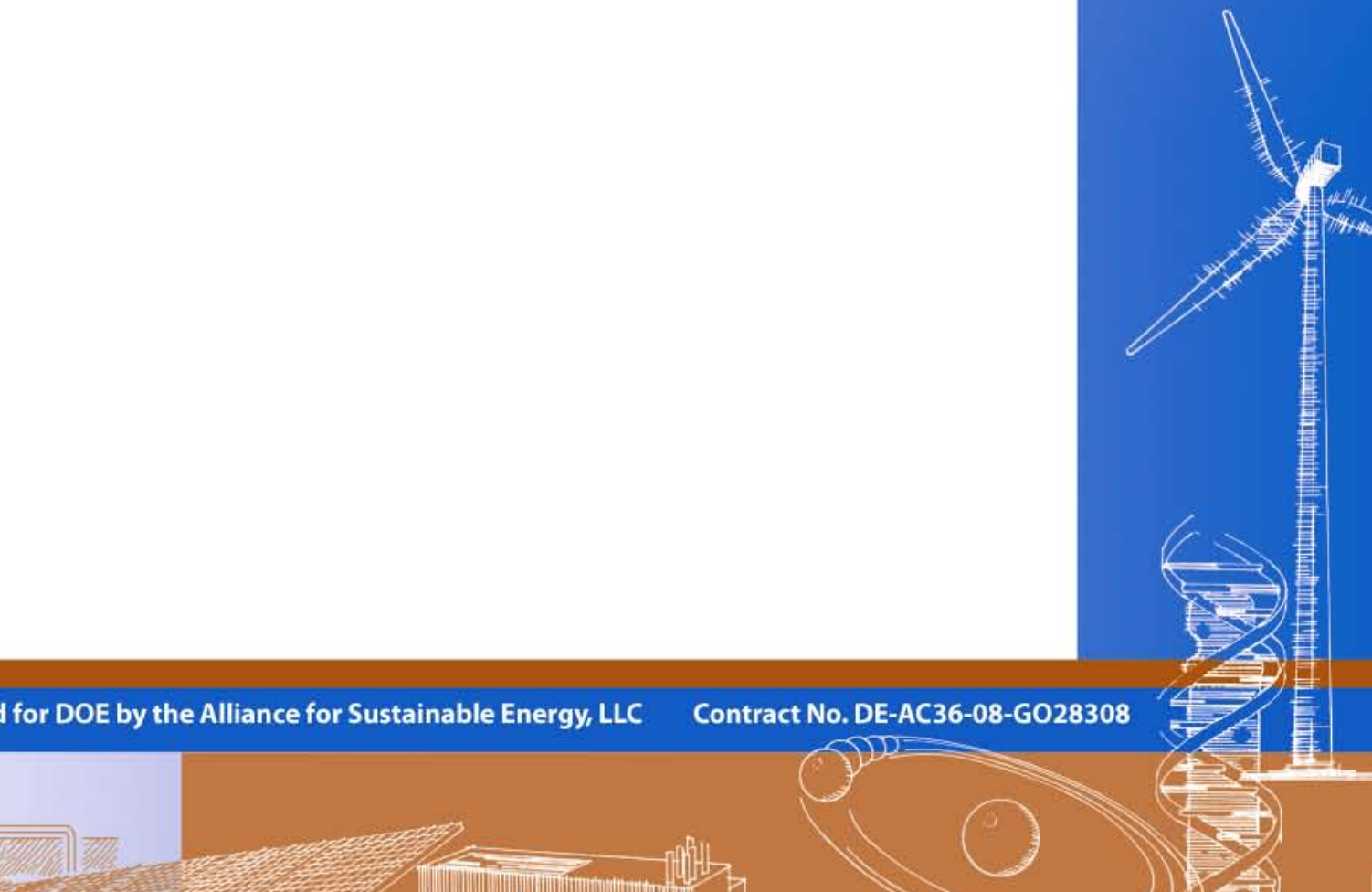


\section{Uncertainty Analysis of Certified Photovoltaic Measurements at the National Renewable Energy Laboratory}

\section{K. Emery}

Prepared under Task No. PVA93420

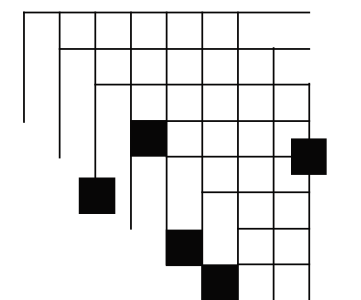




\section{NOTICE}

This report was prepared as an account of work sponsored by an agency of the United States government. Neither the United States government nor any agency thereof, nor any of their employees, makes any warranty, express or implied, or assumes any legal liability or responsibility for the accuracy, completeness, or usefulness of any information, apparatus, product, or process disclosed, or represents that its use would not infringe privately owned rights. Reference herein to any specific commercial product, process, or service by trade name, trademark, manufacturer, or otherwise does not necessarily constitute or imply its endorsement, recommendation, or favoring by the United States government or any agency thereof. The views and opinions of authors expressed herein do not necessarily state or reflect those of the United States government or any agency thereof.

Available electronically at http://www.osti.gov/bridge

Available for a processing fee to U.S. Department of Energy and its contractors, in paper, from:

U.S. Department of Energy

Office of Scientific and Technical Information

P.O. Box 62

Oak Ridge, TN 37831-0062

phone: 865.576 .8401

fax: 865.576 .5728

email: mailto:reports@adonis.osti.gov

Available for sale to the public, in paper, from:

U.S. Department of Commerce

National Technical Information Service

5285 Port Royal Road

Springfield, VA 22161

phone: 800.553.6847

fax: 703.605.6900

email: orders@ntis.fedworld.gov

online ordering: http://www.ntis.gov/ordering.htm 


\section{TABLE OF CONTENTS}

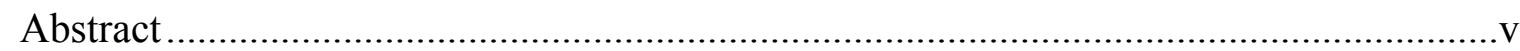

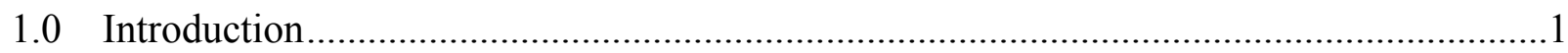

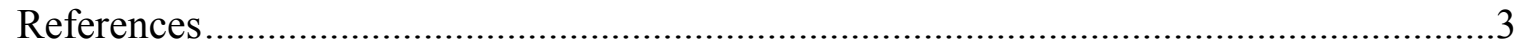

2.0 Uncertainty of Primary Calibration of Photovoltaic Cells.................................................

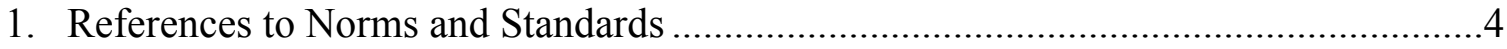

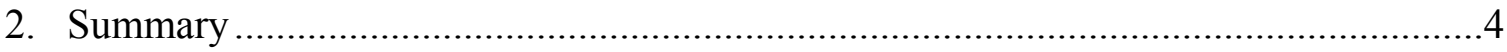

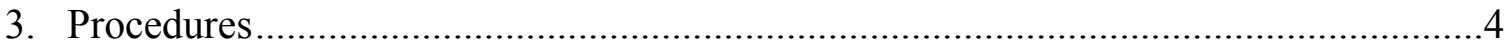

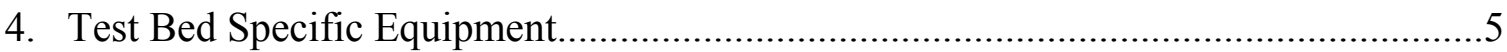

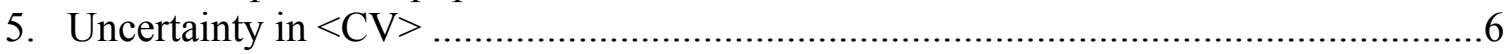

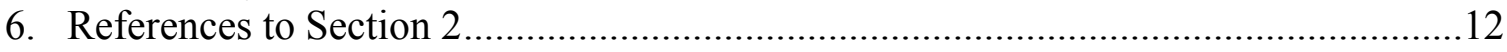

3.0 Uncertainty of Photovoltaic Cell Spectral Responsivity ...................................................15

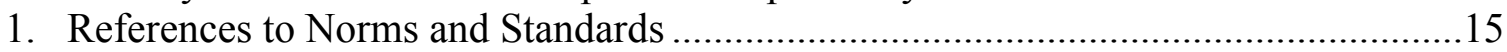

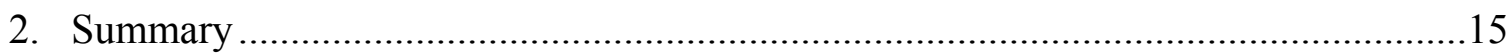

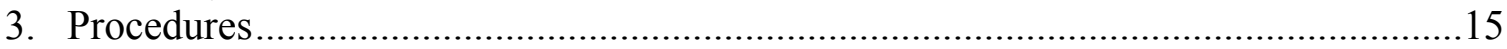

4. Test Bed Specific Equipment...............................................................................16

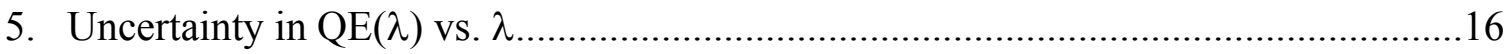

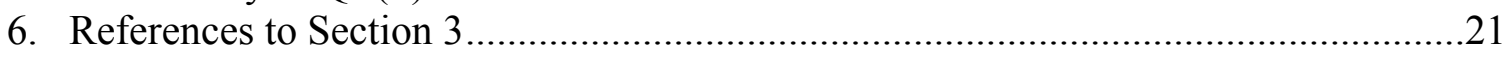

4.0 Uncertainty of Electrical Performance of Photovoltaic Cells............................................22

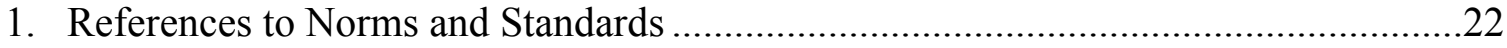

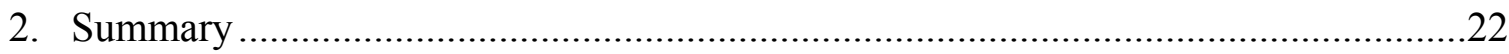

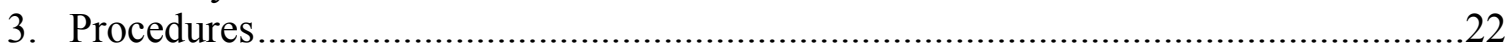

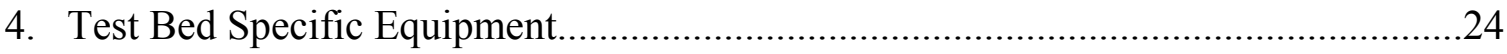

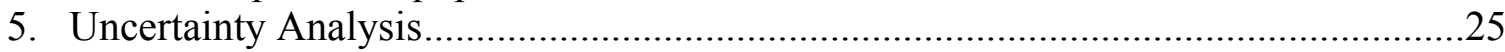

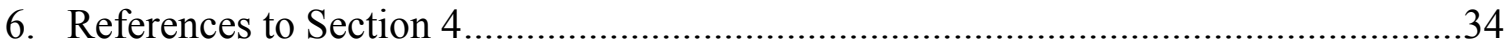

5.0 Uncertainty of Electrical Performance of Photovoltaic Modules .........................................37

1. References to Norms and Standards …………........................................................37

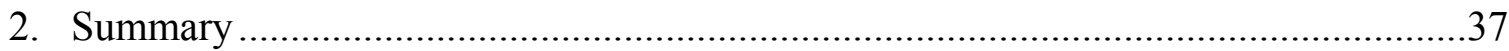

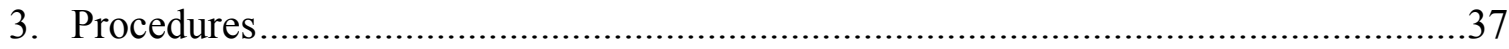

4. Test Bed Specific Equipment..................................................................................4

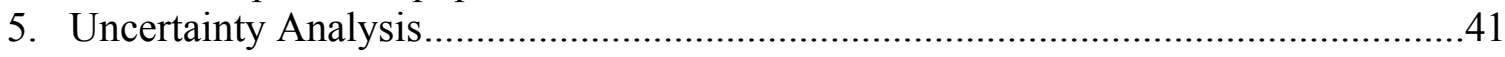

6. References to Section 5 ....................................................................................

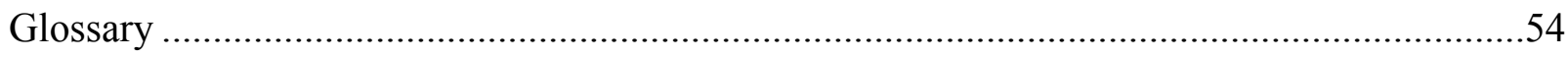

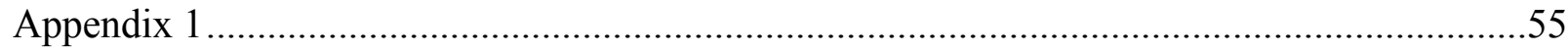

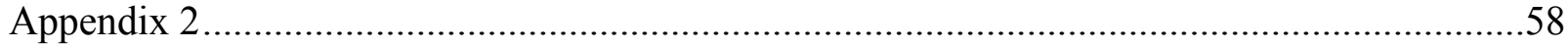




\section{List of Figures}

Figure 1. Irradiance traceability path for NREL's PV Cell and Module Performance Characterization Group........................................................................................

Figure 2. Simplified block diagram of the primary calibration test station ...............................6

Figure 3. Typical annual primary reference cell calibration ....................................................

Figure 4. Quantum efficiency curve of WPVS Reference Cell 930216-1 …...........................8

Figure 5. Frequency of temperatures in the 2002 Primary Reference Cell calibration

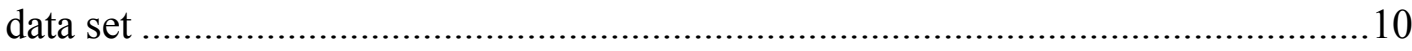

Figure 6. Calibration value measured at NREL compared with the WPVS average value of four international photovoltaic calibration laboratories including NREL ............11

Figure 7. Nineteen years of primary reference cell calibrations on the same mono-Si cell.....11

Figure 8. Seventeen years of primary reference cell calibrations on the same GaAs cell .......12

Figure 9. Filter quantum-efficiency system. This equipment is used to measure the quantum efficiency $(\mathrm{QE})$ of a PV cell.............................................................. 16

Figure 10. QE curve of WPVS reference cell N45 showing the standard deviation and

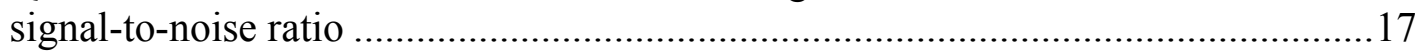

Figure 11. The Spectrolab X25 solar simulator and custom I-V measurement system ..............24

Figure 12. Simplified block diagram of current versus voltage test station................................25

Figure 13. Typical I-V curve for a reference cell...............................................................2

Figure 14. The Spectrolab LACSS solar simulator and custom I-V measurement system.........40

Figure 15. Simplified block diagram of current versus voltage test station.................................40

Figure 16. Typical I-V curve for a cell in module package test device .....................................43

Figure 17. Typical I-V curve for a module test device …………………...............................4

Figure 18. Typical spatial nonuniformity of large-area continuous solar simulator

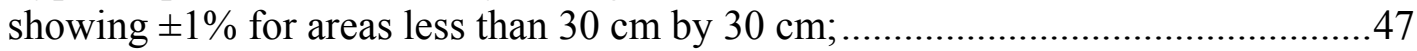

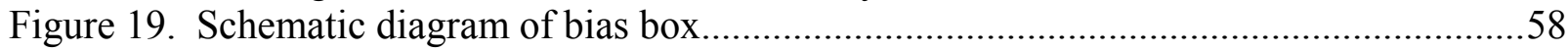

\section{List of Tables}

Table 1. Summary of Standard Primary Reference Cell Uncertainty Components.................... 8

Table 2. Error Sources for Measurement of the Photocurrent …………................................18

Table 3. Error Sources for Measurement of the Light Power ...................................................19

Table 4. Error Sources Related to the Monochromatic Light ..................................................19

Table 5. Detector Measurement Services Uncertainties Relative Expanded

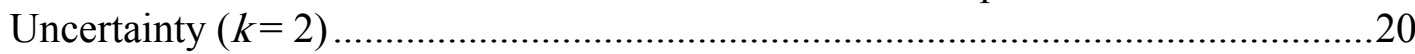

Table 6. Major Errors Sources in Normalized Filter Quantum Efficiency Measurements.....21

Table 7. Summary of Standard Secondary Reference Cell Uncertainty Components.............25

Table 8. Summary of Standard Secondary Reference Module Uncertainty Components.......41 


\begin{abstract}
The measurement of the photovoltaic (PV) performance with respect to reference conditions requires measuring the current versus voltage with respect to a given tabular reference spectrum, junction temperature, and total irradiance. This report briefly discusses the procedures implemented by the PV Cell and Module Performance Characterization Group at the National Renewable Energy Laboratory (NREL) to achieve the lowest practical uncertainty. We present a rigorous uncertainty analysis of these procedures following the International Organization for Standardization (ISO) "Guide to the Expression of Uncertainty in Measurement." This uncertainty analysis is required for our team's laboratory accreditation under ISO standard 17025, "General Requirements for the Competence of Testing and Calibration Laboratories." Our PV cell and module performance laboratory was certified by the American Association for Laboratory Accreditation (A2LA) to perform ISO 17025-accredited calibrations on September 14, 2004. (See Appendix 1 for copies of the certificates.) The two agencies authorized to grant ISO 17025 accreditation in the United States are A2LA and National Voluntary Laboratory Accreditation Program (NAVLAP).
\end{abstract}


(This page intentionally left blank.) 


\subsection{INTRODUCTION}

The phrase "trust but verify" was popular during the Strategic Arms Limitation Talks in the 1980s, where the United States and Soviet Union trusted each other but required continuous unattended monitoring for compliance with treaty obligations. In the scientific community, the peer review process is critical to verify the quality of a manuscript. Errata and letters to the editor allow results to be challenged and defended. All laboratories must trust some other laboratory for at least part of their calibration traceability path for instruments that report a result. The level of trust that one has in a calibration depends on the laboratory's stature as a national calibration facility (e.g., AIST [National Institute of Advanced Industrial Science and Technology], NIST (National Institute of Standards and Technology], or PTB [Physikalisch-Technische Bundesanstalt]), an ISO 17025-accredited calibration laboratory, the original equipment manufacturer, or a national laboratory such as the National Renewable Energy Laboratory (NREL) [1]. National standards laboratories such as NIST for the United States and ISO 17025accredited calibration laboratories have the highest stature because of the rigor in their procedures - a verified quality system.

The same "trust but verify" axiom is applicable to the Photovoltaic Cell and Module Performance Characterization Group at NREL, where our primary function is verifying the performance of PV devices. ISO 17025 requires that these calibrations be performed by a national standards facility such as NIST or an ISO 17025-accredited laboratory. Figure 1 shows the team's calibration traceability chain.

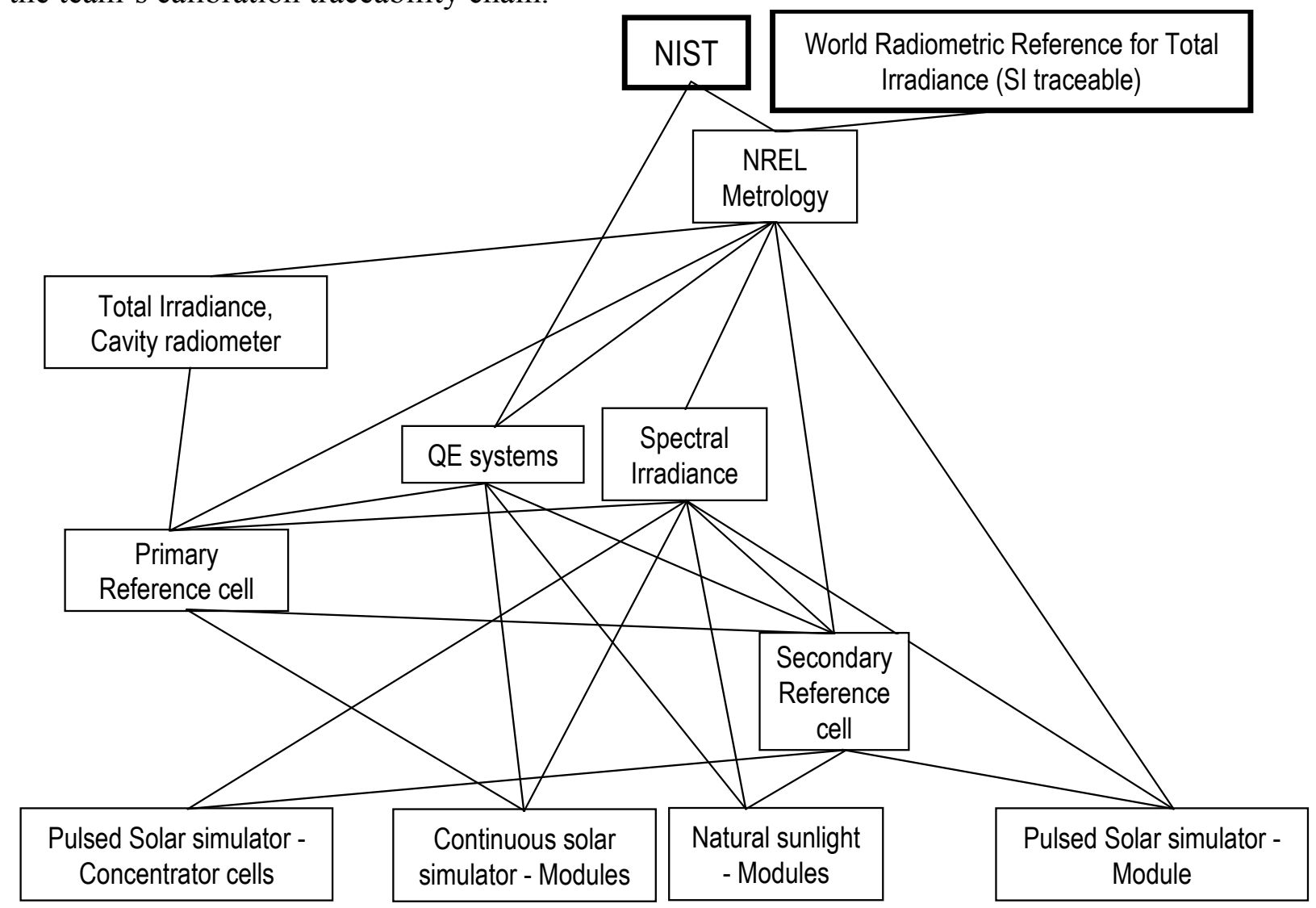

Figure 1. Irradiance traceability path for NREL's PV Cell and Module Performance Characterization Group. Equipment to measure voltage, resistance, current, and temperature is calibrated by NREL's Metrology Group. 
A key requirement for certified calibration laboratories is that they must demonstrate their proficiency though formal uncertainty analysis and periodic intercomparisons. NREL has participated in numerous formal [2-8] and informal intercomparisons over the years. This is an ongoing process where, at any point, an intercomparison could reveal differences outside of estimated uncertainty limits. When this occurs, a detailed uncertainty analysis of both groups' methods often reconciles differences.

To perform a rigorous uncertainty analysis, one must choose typical cases and make a variety of assumptions such as equipment in calibration, trained operators, and best practices followed as documented in the test-bed work instructions. The samples chosen in these uncertainty analyses were a typical $2-\mathrm{cm}$ by $2-\mathrm{cm}$ packaged silicon $(\mathrm{Si})$ reference cell and an $18-\mathrm{W}$ commercial $\mathrm{Si}$ module. The scope of the uncertainty analysis for cells was based on the American Society for Testing and Materials (ASTM) standard E1040 and International Electrotechnical Commission (IEC) standard 60904-2 requirements for packaged reference cells and was restricted to singlejunction technologies. Voltage and current limitations should not eliminate any cell technology that fits within the area limitation. The scope for the modules is restricted to single-junction technologies and by physical dimensions. The current and voltage limitations for the module measurements cover all known and planned cell and flat-module currents and voltages for samples that satisfy the size constraint.

Our requirements for an ISO 17025-certified calibration of a single-junction secondary reference cell or module are the following:

- Permanent sample identification (ID) must be marked on the sample.

- An attached temperature sensor is required for cell calibrations of type J, K, T thermocouple, a thermistor, or resistance temperature detector (RTD). The sensor type must be specified or obvious by the type of thermocouple connector. No attached temperature sensor is allowed for module calibrations.

- Two voltage and two current wires are connected to the sample.

- The cell must be mounted in a metal package for temperature control for cell calibration; it is otherwise eligible for module calibration. The package should be mechanically sound and protected from damage during shipment and handling. An air gap between the sensor and any window is allowed.

- Any required mating connector should be supplied with the wires identified (+, -, current, voltage).

- The spectral responsivity of the module must be determined via a cell that is representative of the module or wires connected to a single cell in the module being calibrated.

- There should be no inherent instabilities or metastable behavior such as in amorphous silicon.

- The maximum $\mathrm{V}_{\text {oc }}$ for cells is $40 \mathrm{~V}$ and for modules is $290 \mathrm{~V}$. The minimum $\mathrm{V}_{\text {oc }}$ for cells is $0.1 \mathrm{~V}$ and for modules is $0.5 \mathrm{~V}$.

- The maximum $\mathrm{I}_{\mathrm{sc}}$ for cells is $15 \mathrm{~A}$ and for modules is $50 \mathrm{~A}$. The minimum $\mathrm{I}_{\mathrm{sc}}$ for cells is $1 \mathrm{~mA}$ and for modules is $100 \mathrm{~mA}$.

- The area must be between $0.5 \mathrm{~cm}$ by $0.5 \mathrm{~cm}$ and $20 \mathrm{~cm}$ by $20 \mathrm{~cm}$ for cells. The area must be between $1 \mathrm{~cm}$ by $1 \mathrm{~cm}$ and $150 \mathrm{~cm}$ by $120 \mathrm{~cm}$ for modules. 


\section{References}

1. K. Emery, A. Anderberg, J. Kiehl, C. Mack, T. Moriarty, L. Ottoson, and S. Rummel, "Trust But Verify: Procedures to Achieve Accurate Efficiency Measurements for All Photovoltaic Technologies," Proc. 31 $1^{\text {st }}$ IEEE PVSC, Orlando FL, pp.1781-1784, Jan. 3-7, 2005.

2. H. Ossenbrink, R. Van Steenwinkel, and K. Krebs, "The Results of the 1984/1985 RoundRobin Calibration of Reference Solar Cells for the Summit Working Group on Technology, Growth and Employment," Joint Research Center, ISPRA Establishment, ISPRA Italy, Tech Rep. EUR 10613 EN (April 1986).

3. K.A. Emery, C.R. Osterwald, L.L. Kazmerski, and R.E. Hart, "Calibration of Primary Terrestrial References Cells When Compared with Primary AM0 Reference Cells," Proc. $8^{\text {th }}$ European Photovoltaic Solar Energy Conf., Florence, Italy, May 9-12, 1988, pp.64-68.

4. J. Metzdorf, T. Wittchen, K. Heidler, K. Dehne, R. Shimokawa, F. Nagamine, H. Ossenbrink, L. Fornarini, C. Goodbody, M. Davies, K. Emery, and R. Deblasio, "Objectives and Results of the PEP '87 Round-Robin Calibration of Reference Cells and Modules," Proc. $21^{\text {st }}$ IEEE Photovoltaic Specialists Conf., Orlando, FL, May 21-25, 1990, pp.952-959, IEEE, New York, 1990. (invited)

5. J. Metzdorf, T. Wittchen, K. Heidler, K. Dehne, R. Shimokawa, F. Nagamine, H. Ossenbrink, L. Fornarini, C. Goodbody, M. Davies, K. Emery, and R. Deblasio, "The Results of the PEP '87 Round-Robin Calibration of Reference Cells and Modules,- Final Report," PTB Technical Report PTB-Opt-31, Braunschweig, Germany, November 1990, ISBN 389429-067-6.

6. C.R. Osterwald, S. Anevsky, A.K. Barua, J. Dubard, K. Emery, D. King, J. Metzdorf, F. Nagamine, R. Shimokawa, N. Udayakumar, Y.X. Wang W. Zaaiman, A. Zastrow, and J. Zhang, "Results of the PEP '93 Intercomparison of Reference Cell Calibrations and Newer Technology Performance Measurements," Proc. $25^{\text {th }}$ IEEE Photovoltaic Specialists Conf., Washington D.C., May 13-17, 1996, pp.1263-1266, IEEE, New York, 1996.

7. C.R. Osterwald, S. Anevsky, A.K. Barua, J. Dubard, K. Emery, D. King, J. Metzdorf, F. Nagamine, R. Shimokawa, N. Udayakumar, Y.X. Wang W. Zaaiman, A. Zastrow, and J. Zhang, "The Results of the PEP '93 Intercomparison of Reference Cell Calibrations and Newer Technology Performance Measurements: Final Report," March 1998, NREL Tech. Rep. NREL/TP-520-23477.

8. S. Rummel, A. Anderberg, K. Emery, D. King, G. TamizhMani, T. Arends, G. Atmaram, L. Demetrius, W. Zaaiman, N. Cereghetti, W. Herrmann, W. Warta, F. Neuberger, K. Morita, and Y. Hishikawa, "Results from the Second International Module Inter-comparison," Proc. IEEE $4^{\text {th }}$ World Conference on Photovoltaic Energy Conversion, pp.2034-2037, May 7-12, 2006 Waikoloa, HI. 


\subsection{UNCERTAINTY OF PRIMARY CALIBRATION OF PHOTOVOLTAIC CELLS}

\section{Reference to Norms and Standards}

- ASTM E1125, "Standard Test Method for Calibration of Primary Non-Concentrator Terrestrial Photovoltaic Reference Cells Using a Tabular Spectrum"

- Procedure ISO GUM "International Organization for Standardization, Guide to the Expression of Uncertainty in Measurement. ISO: Geneva, 1995, ISBN 92-67-10188-9.

- ISO-VIM "International Vocabulary of Basic and General Terms in Metrology," $2^{\text {nd }}$ Edition 1993.

- ASTM standard E 1328 Terminology Relating to Photovoltaic Solar Energy Conversion"

\section{Summary}

This uncertainty analysis is for ASTM E1125, "Standard Test Method for Calibration of Primary Non-Concentrator Terrestrial Photovoltaic Reference Cells Using a Tabular Spectrum" [1]. The analysis is restricted to single-junction monocrystal or multicrystal $\mathrm{Si}$, GaAs, GaInP, GaInAs, $\mathrm{Ge}$, or InP cells that are packaged with connectors [2]. Other technologies or unpackaged samples have additional error sources related to contacting and a larger spectral-mismatch correction. This analysis is restricted to samples less than $4 \mathrm{~cm}^{2}$ in area. The calibration value of the PV reference cell is determined with respect to a reference temperature (typically $25^{\circ} \mathrm{C}$ ) and reference irradiance (typically ASTM G159 global [3], $1000 \mathrm{~W} / \mathrm{m}^{2}$ ). In September 2008, our group switched to the ASTM G173 [4] reference spectrum. This new spectrum is nearly identical to the old spectrum (currents were affected by less than $1 \%$ for most cases, and $2 \%$ for all typical PV technologies). The group has essentially been following these procedures since 1984 [5-18].

\section{Procedures}

The procedure from E1 125 follows:

1. Mount the reference cell to be calibrated, collimator, absolute cavity radiometer, and spectral irradiance measurement equipment on the tracking platforms.

2. Measure the relative spectral irradiance of the sun, $E_{\mathrm{S}}(\lambda)$, using the spectral irradiance measurement instrument and the procedure of Test Method E 1341 [20]. During the spectral irradiance measurement, perform steps 2.1 and 2.2 simultaneously.

2.1. Measure the absolute cavity radiometer output, $E_{t}$, and verify that the total irradiance is between 750 and $1100 \mathrm{Wm}^{-2}$.

2.2. Measure the reference cell short-circuit current, $I_{s c}$.

2.3. Calculate the calibration value

$$
C V_{U}=I_{s c} / E_{T}
$$

2.4. Measure the reference cell temperature, $T_{m}$. 
2.5. Repeat 2.1 through 2.3 at least four times. These repetitions must be distributed in time during the spectral irradiance measurement.

2.6. Average the calibration values from 2.3.

3. Perform a minimum of five replications of step 2 on at least three separate days.

4. Extend the measured spectral irradiance to 300-4000 $\mathrm{nm}$ to encompass the limits of the reference spectrum given in Ref. 3 using the procedure described in $[8,11,12]$.

5. Correct each measured $C V_{u}$ in step 2.6 for temperature to $25^{\circ} \mathrm{C}$ using

$$
C V_{u}\left(25^{\circ} C\right)=C V_{u}\left[1+\frac{10^{-6} \cdot T_{\text {coef }} \cdot\left(25^{\circ} C-T_{m}\right)}{1-T_{\text {coef }} \cdot 10^{-6} \cdot\left(25^{\circ} C-T_{m}\right)}\right]=C V_{u} \cdot M_{t}
$$

where $T_{\text {coef }}$ is the temperature coefficient of the short-circuit current in ppm $/{ }^{\circ} \mathrm{C}$ normalized to $25^{\circ} \mathrm{C}$.

$$
C V=C V_{u}\left(25^{\circ} C\right) \cdot \frac{\int_{300}^{4000} E_{r e f}(\lambda) \cdot S_{r}(\lambda) \mathrm{d} \lambda}{\int_{300}^{4000} E_{r e f}(\lambda) \mathrm{d} \lambda} \cdot \frac{\int_{300}^{4000} E_{s}(\lambda) \mathrm{d} \lambda}{\int_{300}^{4000} E_{s}(\lambda) \cdot S_{r}(\lambda) \mathrm{d} \lambda}=\frac{I_{s c} \cdot M_{T} \cdot k}{E_{t}}
$$

where:

$$
\begin{array}{ll}
S_{r}(\lambda) & \text { Spectral responsivity of the reference cell (Test Method E1021[21]) } \\
E_{r e f}(\lambda) & \text { Reference spectral irradiance } \\
E_{S}(\lambda) & \text { Direct-beam solar spectral irradiance (Practice E1341[20]) } \\
k & \text { Spectral correction factor }
\end{array}
$$

5.1. Calculate Eqs. 1 and 2 for all points on all days and compute the mean corrected calibration value, $\langle C V$.

5.2. Reject any points that meet the following criteria:

- $C V$ more than $1.5 \%$ from the $<C V\rangle$

- $I_{s c}$ range is greater than $1.5 \%$

- $C V_{u}\left(T_{m}\right)$ standard deviation is greater than $1 \%$.

6. Verify that at least three days data with a minimum of five sets / day of valid data exist. If not, repeat steps $1-5$ until all criteria are met.

7. Generate a test report / cover letter.

8. Have the data, record book, test report, and cover letter reviewed by someone familiar with the procedures, but who was not involved in the measurement.

\section{Test-Bed-Specific Equipment}

Figure 2 is a simplified block diagram of the test bed. 


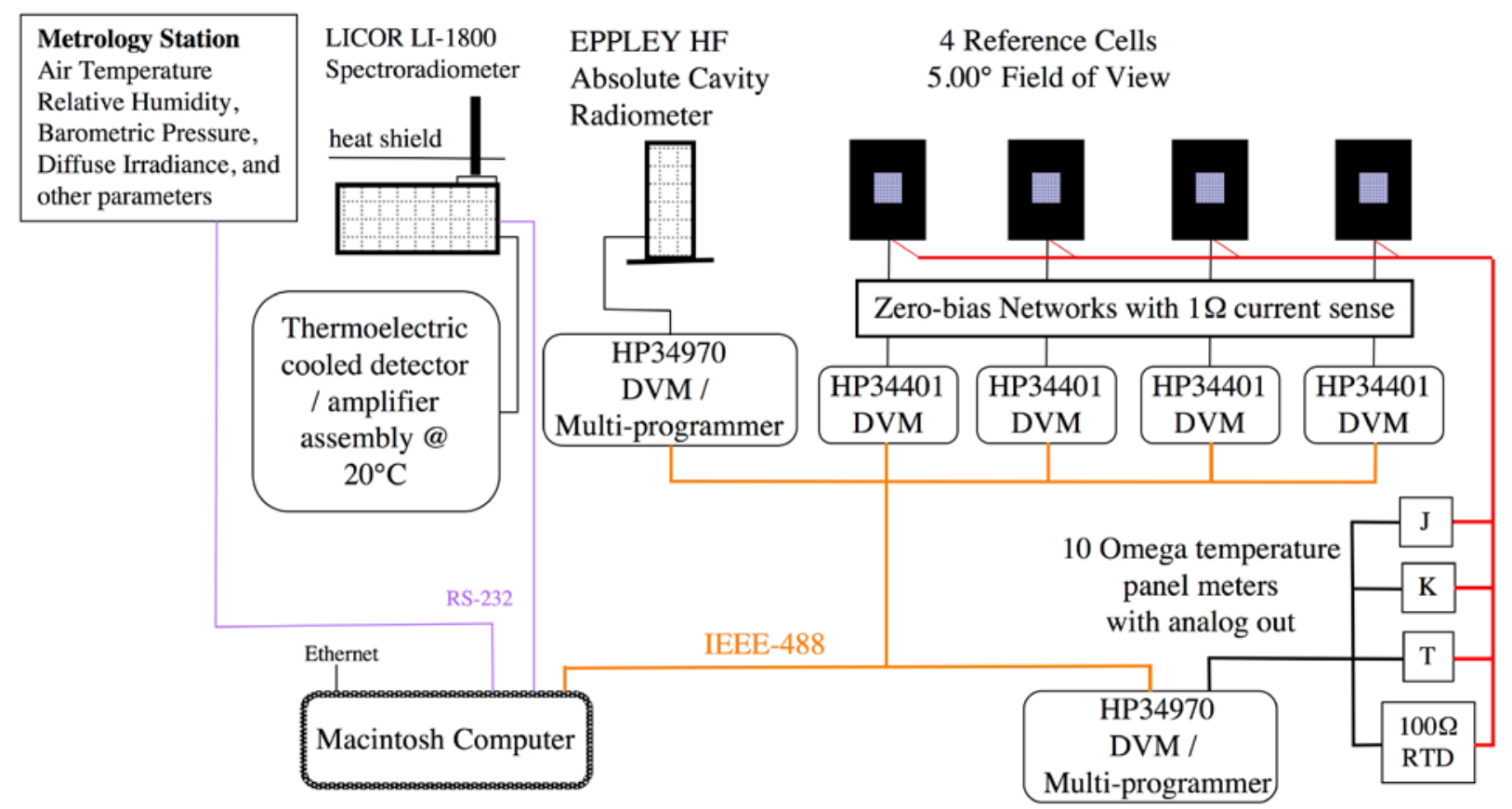

Figure 2. Simplified block diagram of the primary calibration test station.

\section{Uncertainty in $\langle\mathrm{CV}\rangle$}

The uncertainty in the average temperature and spectrally corrected calibration value $<C V\rangle$ from Eq. 3 is determined using standard uncertainty analysis based on [2,23]. For convenience, the elemental Type A and Type B error sources will be expressed in terms of percentage of value. The analysis is based on the best measurement capability and represents the smallest uncertainty of nearly ideal PV reference cells. This means that the cells should be stable with no measurable degradation, packaged with wires and temperature sensors, and close to $2 \mathrm{~cm}$ by $2 \mathrm{~cm}$ in area. To simplify matters, the uncertainties of the input quantities are expressed in terms of percentage of value. Since all equations are or will be reduced to multiplications and divisions, the sensitivity coefficient reduces to unity. The uncertainty of the performance parameters will then be the same for similar cells. To express the uncertainty as a percentage, a typical case is used so that the voltmeter range and resolution can be converted to a percentage. The 2002 calibration of the World Photovoltaic Scale (WPVS) reference cell 930216-1 is used as a typical example of a $\mathrm{Si}$ reference cell (Fig. 3). 


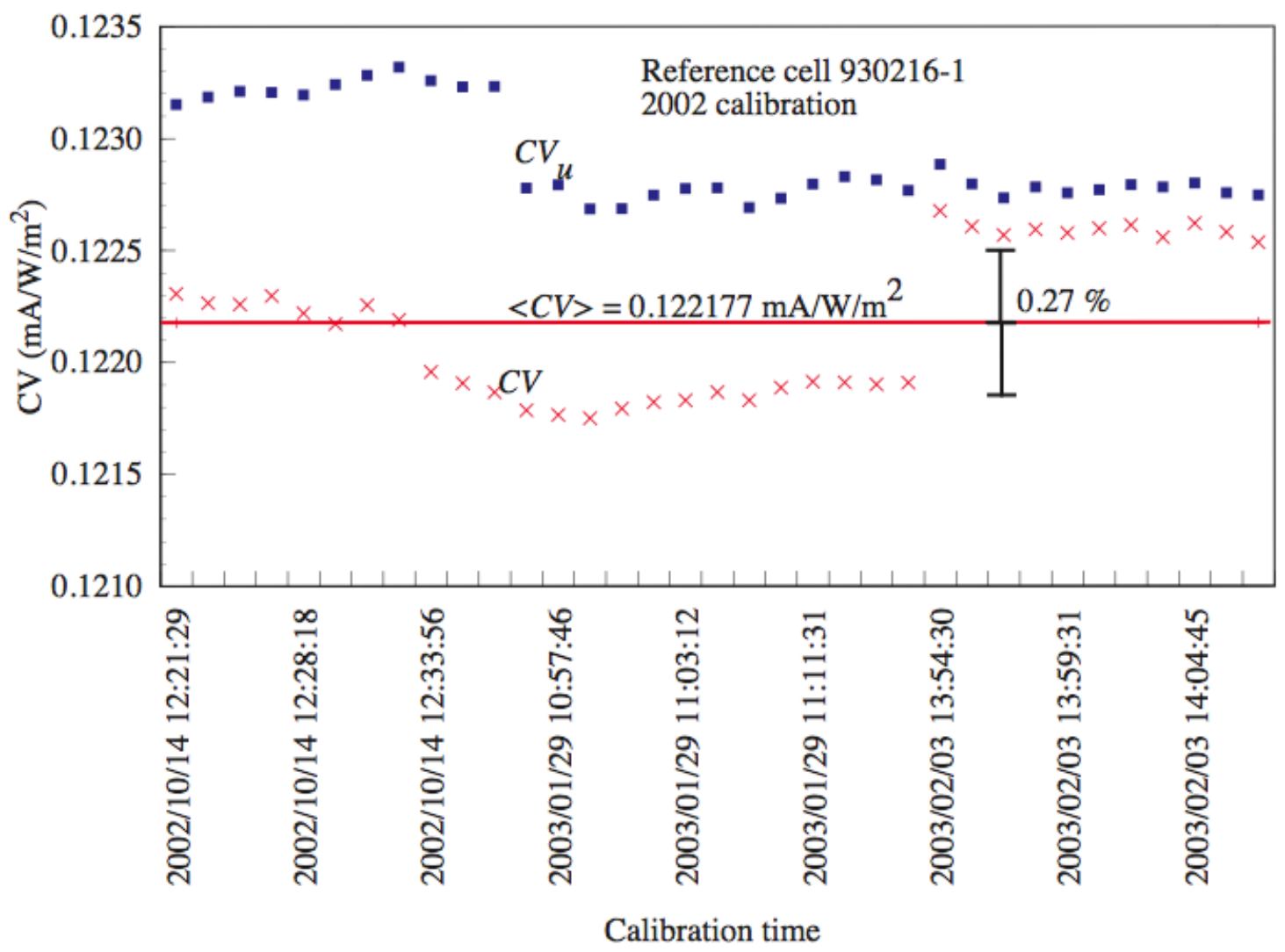

Figure 3. Typical annual primary reference cell calibration.

The WPVS value for $930216-1$ at standard reference conditions $\left(25^{\circ} \mathrm{C}, 1000 \mathrm{Wm}^{-2}\right.$, global) is $123.29 \mathrm{~mA} \mathrm{[15-18]}$. The spectral responsivity is given in Fig. 4. With the uncertainty components expressed as a percentage using Eqs. 1 through 3, the uncertainty in the mean calibration value $<C V\rangle$ can be written with a coverage factor of 2 for $95 \%$ confidence as

$$
U_{<C V\rangle}=2\left[\left(\frac{U_{I_{s c}}}{\sqrt{3}}\right)^{2}+\left(\frac{U_{C V_{U}\left(25^{\circ} C\right)}}{\sqrt{n}}\right)^{2}+\left(\frac{U_{C V_{U}}}{\sqrt{n^{\prime}}}\right)^{2}+\left(\frac{U_{E_{t}}}{2}\right)^{2}++\left(\frac{U_{M_{T}}}{2}\right)^{2}+\left(\frac{U_{k}}{2}\right)^{2}\right]^{0.5}
$$

The type A error sources are from n' readings of $I_{s c}$ and $E_{t}$ to obtain one $C V_{u}$. Using Eq. 3 , n data sets of $C V$ are averaged to obtain $\langle C V$. Table 1 lists the various uncertainty components and their values. 


\section{PRC (Germany) \\ mono-Si Ref. Cell}
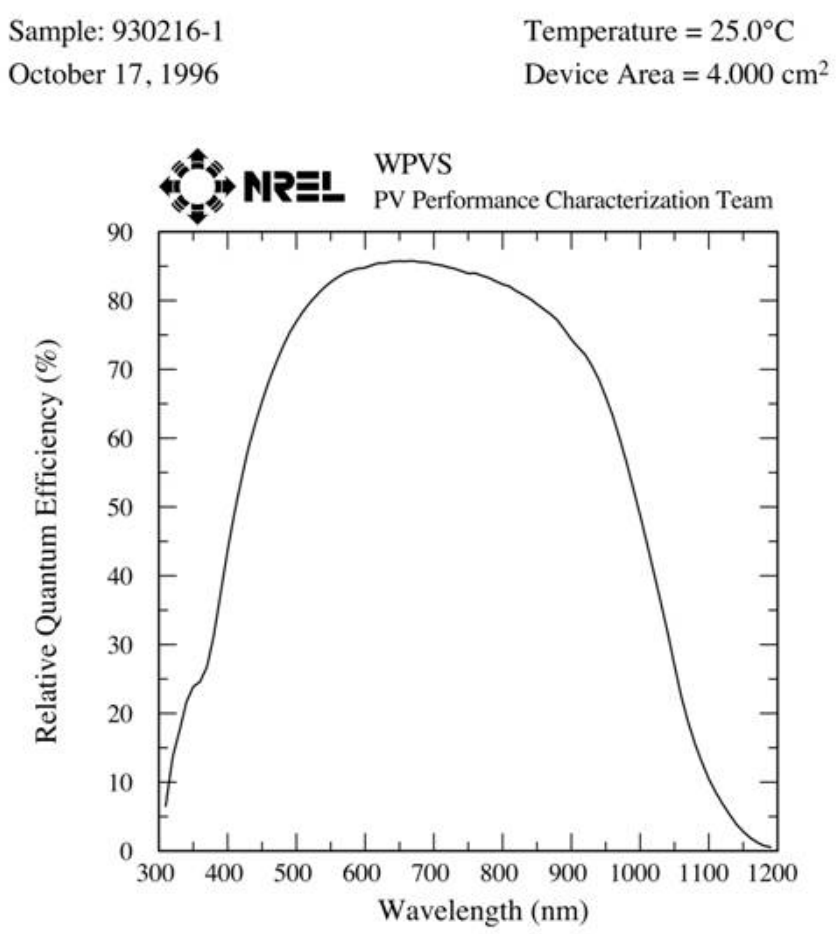

Figure 4. Quantum efficiency curve of WPVS Reference Cell 930216-1.

Table 1. Summary of Standard Primary Reference Cell Uncertainty Components

\begin{tabular}{llll}
\hline $\begin{array}{l}\text { Uncertainty } \\
\text { Component }\end{array}$ & \multicolumn{1}{c}{ Source of Uncertainty } & $\begin{array}{c}\text { Value of } \\
\text { Uncertainty } \\
(\%)\end{array}$ & $\begin{array}{c}\text { Coverage } \\
\text { Factor }\end{array}$ \\
\hline$U_{I s c}$ & Measured $I_{s c}$ & 0.029 & Rectangular \\
\hline$U_{C V u\left(25^{\circ} \mathrm{C}\right)}$ & Corrected calibration value & 0.27 & $\mathrm{n}=35$ \\
\hline$U_{C V u}$ & Uncorrected calibration value & 0.083 & $\mathrm{n}=85$ \\
\hline$U_{E t}$ & Measured total irradiance & 0.34 & Rectangular \\
\hline$U_{M T}$ & Temperature correction & 0.14 & Rectangular \\
\hline$U_{k}$ & Spectral correction & 0.80 & Gaussian \\
\hline$U_{\text {meter }}$ & Reference cell DMM (123 mA typical value) & 0.021 & Rectangular \\
\hline & From data sheet, confidence value not listed & & \\
\hline & 1-year HP34401, 10 V, of reading & 0.0035 & Rectangular \\
\hline & 1-year HP34401, 10 V, of range & 0.0005 & Rectangular \\
\hline & 1-year HP34401, 10 V, 1 line cycle & 0.001 & Rectangular \\
\hline & HP34401, 10 V, temperature 23 $\pm 10^{\circ} \mathrm{C}$ & 0.005 & Rectangular \\
\hline$U_{\text {resistor }}$ & 1-year resistor calibration uncertainty & 0.02 & Gaussian \\
\hline$U_{\text {stability }}$ & Resistor 1-year stability (Julie CH-48T4 data sheet $)$ & 0.003 & Rectangular \\
\hline
\end{tabular}

The measured $I_{s c}$ is the voltage measured across a 10 -ohm resistor with an Agilent 34401A multimeter with a 10-power-line cycle integration period. The circuit used to bias the reference cell within $2 \mathrm{mV}$ of $0 \mathrm{~V}$ is described in Appendix 2. From the typical case in Figs. 3 and 4, the measured voltage is taken to be $1.23 \mathrm{~V}$. From the 1-year manufacturer's specification, the 
uncertainty on the $10-\mathrm{V}$ range is $0.0040 \%$ of the reading plus $0.0007 \%$ of the range. The distribution is assumed to be rectangular because the data sheet does not specify the confidence value. The meter uncertainties supplied by the manufacturer are based on a $23 \pm 5^{\circ} \mathrm{C}$ operating temperature. Resistors and meters are in a temperature-controlled room at $23 \pm 5^{\circ} \mathrm{C}$. The maximum expected resistor and meter temperature deviation is $23 \pm 10^{\circ} \mathrm{C}$. The temperature coefficient of the meter outside of the $23 \pm 5^{\circ} \mathrm{C}$ is $0.0005 \% /{ }^{\circ} \mathrm{C}$ of the reading and $0.0001 \% /{ }^{\circ} \mathrm{C}$ for the $10-\mathrm{V}$ range. The total error of the voltage reading across the $10-\mathrm{ohm}$ current sense resistor is

$$
\begin{aligned}
U_{\text {meter }}= & {[\% \text { of range }+ \text { temperature correction }]+[\% \text { of reading }+ \text { temperature correction }]=} \\
& 100 \cdot\{[(0.0035+10 \cdot 0.0005) \cdot 0.01 \cdot 1.23]+ \\
& {[(0.0005+10 \cdot 0.0001) \cdot 0.01 \cdot 10]\} / 1.23=0.021 \% }
\end{aligned}
$$

The temperature coefficient for the 10 -ohm resistor manufactured by Julie Research Laboratory (now manufactured by Ohm-Labs) is $5 \mathrm{ppm} /{ }^{\circ} \mathrm{C}$ or $0.0005 \% /{ }^{\circ} \mathrm{C}$. The uncertainty of the 10 -ohm resistor calibrated at NREL is $0.02 \%$ with $95 \%$ confidence level. The 1-year stability of the resistor is $0.003 \% / y e a r$ from the data sheet. The power rating of the resistor is $6 \mathrm{~W}$, and the power dissipated across the resistor of $\left[10 \mathrm{ohm} \cdot(0.123 \mathrm{~A})^{2}=150 \mathrm{~mW}\right]$ is negligible. Hence, the uncertainty in $I_{s c}\left(T_{m}\right)$ is taken to be

$$
\begin{aligned}
U_{I_{s c}} & =\left[\left(U_{\text {meter }}\right)^{2}+\left(T_{\text {resistor }} \cdot T_{\text {coeficient-resistor }}\right)^{2}+\left(U_{\text {resistor }}\right)^{2}+\left(U_{\text {stability }}\right)^{2}\right]^{0.5} \\
& =\left[(0.021)^{2}+(10 \cdot 0.005)^{2}+(0.02)^{2}+(0.003)^{2}\right]^{0.5} \\
& =0.029 \% .
\end{aligned}
$$

The distribution is taken to be rectangular in the absence of further information.

The total irradiance of the absolute cavity radiometer is a voltage measured with an Agilent 34970A multimeter with 10-power-line cycle integration period. The absolute cavity radiometer is calibrated on an annual basis as a unit with the same cabling and electronics used in the calibration of reference cells. The uncertainty in $E_{t}$ is estimated to be $0.34 \%$ with a rectangular coverage factor $[24,25]$.

The uncertainty in the spectral correction factor $k$, is a function of the magnitude of the correction factor $[9,25]$. A conservative estimate of the spectral correction factor uncertainty is $20 \%$ of the value of $[9,25]$. Considering the restrictions on the cells and the clear-sky conditions under which primary calibrations take place, the spectral correction factor is typically less than $2 \%$ for $\mathrm{Si}$ (0.98 to 1.02). For the 2002 data set for 930216-1, the spectral correction factor varied from 0.997 to 0.989 . Experience with spectral corrections of outdoor primary calibration data of less than $2 \%$ indicate that the uncertainty $U_{k}$ is $0.80 \%$. The spectral correction factor is twice as large as simulator-based spectral corrections because of uncertainties in the spectral model extrapolation of the measured spectral irradiance from a 350-1000-nm wavelength range to a 300-4000-nm wavelength range. The uncertainty in $k$ is type B because there is only one spectral correction factor for each data point. The distribution is taken to be normal (Gaussian) based on Monte Carlo perturbation analysis $[9,25]$.

The PV temperature is controlled to a nominal $25^{\circ} \mathrm{C}$. The temperature is measured using the temperature sensor that is permanently attached to the reference cell. This means that, by definition, there is no error in the temperature sensor because all measurements of the PV reference cell are based on a $25^{\circ} \mathrm{C}$ cell temperature as measured by the attached sensor. Hence, 
the only error is in the correction of the data to the reference temperature. The entire 2002 calibration set of 2233 data sets for 50 reference cells had a temperature range of $19.5^{\circ}$ to $31.5^{\circ} \mathrm{C}$. Figure 5 shows the distribution of temperatures.

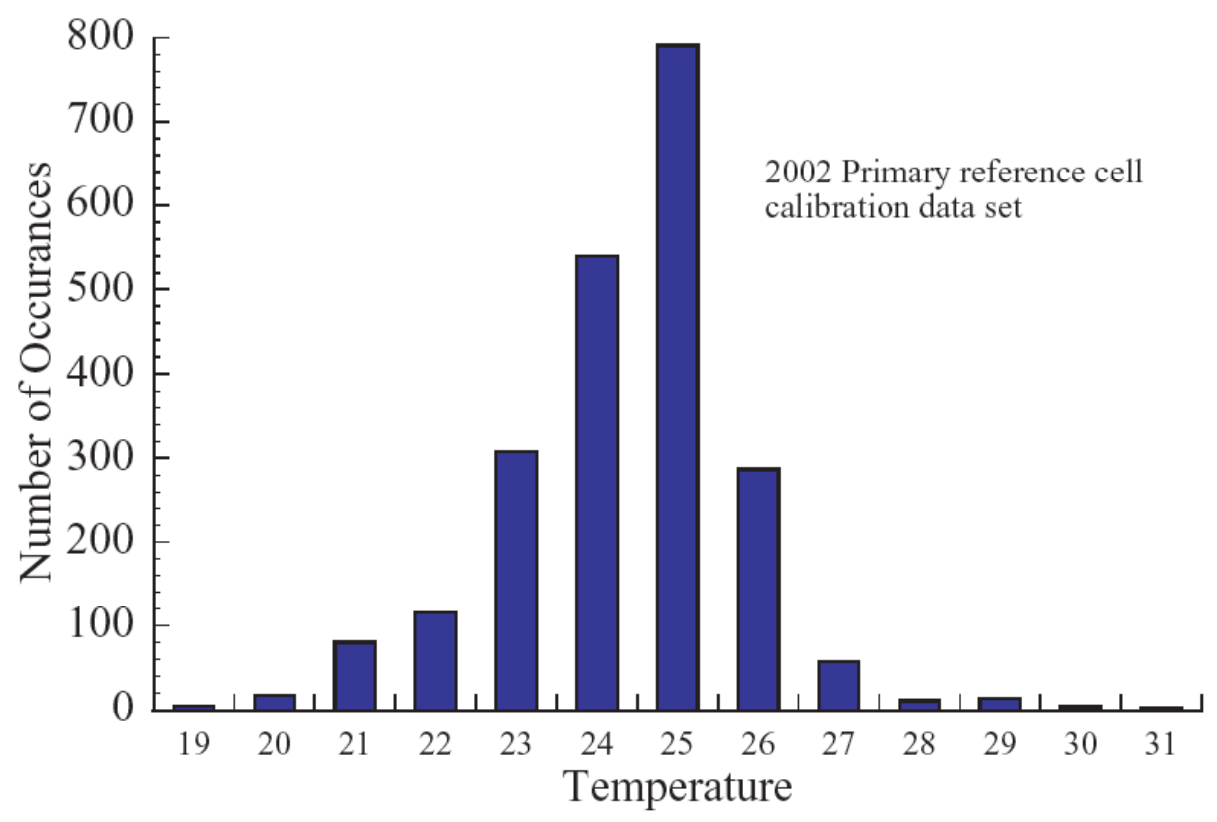

Figure 5. Frequency of temperatures in the 2002 Primary Reference Cell calibration data set.

For convenience, the uncertainty in the correction will be based on a $2^{\circ} \mathrm{C}$ correction with a $I_{s c}$ temperature coefficient of $456 \mathrm{ppm} /{ }^{\circ} \mathrm{C}=0.0456 \% /{ }^{\circ} \mathrm{C}$. The uncertainty in the temperature coefficient can be estimated from the PEP intercomparison, where the WPVS temperature coefficient for 930216-1 was established [15,17,26]. The temperature coefficient for 930216-1 measured independently at six laboratories varied from 250 to $600 \mathrm{ppm} /{ }^{\circ} \mathrm{C}$ [15]. Taking this range of temperature coefficient values for $\mathrm{a} \pm 4^{\circ} \mathrm{C}$ correction for temperature gives a temperature correction of $0.10 \%$ to $0.24 \%$. The distribution is rectangular. Thus, $U_{\text {Tcoef }}=0.24-0.10=0.14 \%$.

Type A error sources arise from the calculation of $C V_{u}$ for a single data set and $\langle C V\rangle$ for all of the data sets. The standard deviation for $C V_{u}$ ranges from $0.054 \%$ to $0.125 \%$, with an average standard deviation of $0.083 \%$. The number of $\mathrm{I}_{s c}\left(T_{m}\right) / E_{t}$ readings during the spectral irradiance measurement equal to 85 are averaged to give $C V_{u}$. The standard deviation for $\langle C V\rangle$ for the 2002 calibration of $930216-1$ was $0.27 \%$ based on 35 data sets. Figure 3 shows $<C V\rangle, C V$, and $C V_{l}$.

Using Eq. 4, the expanded uncertainty with $95 \%$ confidence (coverage $=2$ ) in the calibration value is

$$
\begin{aligned}
U_{<C V>} & =2\left[\left(\frac{0.021}{\sqrt{3}}\right)^{2}+\left(\frac{0.27}{\sqrt{35}}\right)^{2}+\left(\frac{0.083}{\sqrt{85}}\right)^{2}+\left(\frac{0.34}{\sqrt{3}}\right)^{2}+\left(\frac{0.14}{\sqrt{3}}\right)^{2}+\left(\frac{0.80}{2}\right)^{2}\right]^{0.5} \\
& =0.91 \%
\end{aligned}
$$

As a check on the uncertainty estimates, the calibration value for a specific reference cell as a function of time can be examined. The following figures list the calibration value as a function of time for several primary reference cells. Figure 6 shows the history of NREL's two WPVS- 
calibrated reference cells (15-17). The NREL primary calibration method was also performed near sea level in a different climate zone under less-than-ideal conditions in late March and early April of 2003 at the European Solar Test Installation (ESTI). Figures 7 and 8 show the calibration history of a mono-Si and GaAs cell, respectively. The letter "a" after the year in Figs. $6-8$ indicates a significant change in the software.

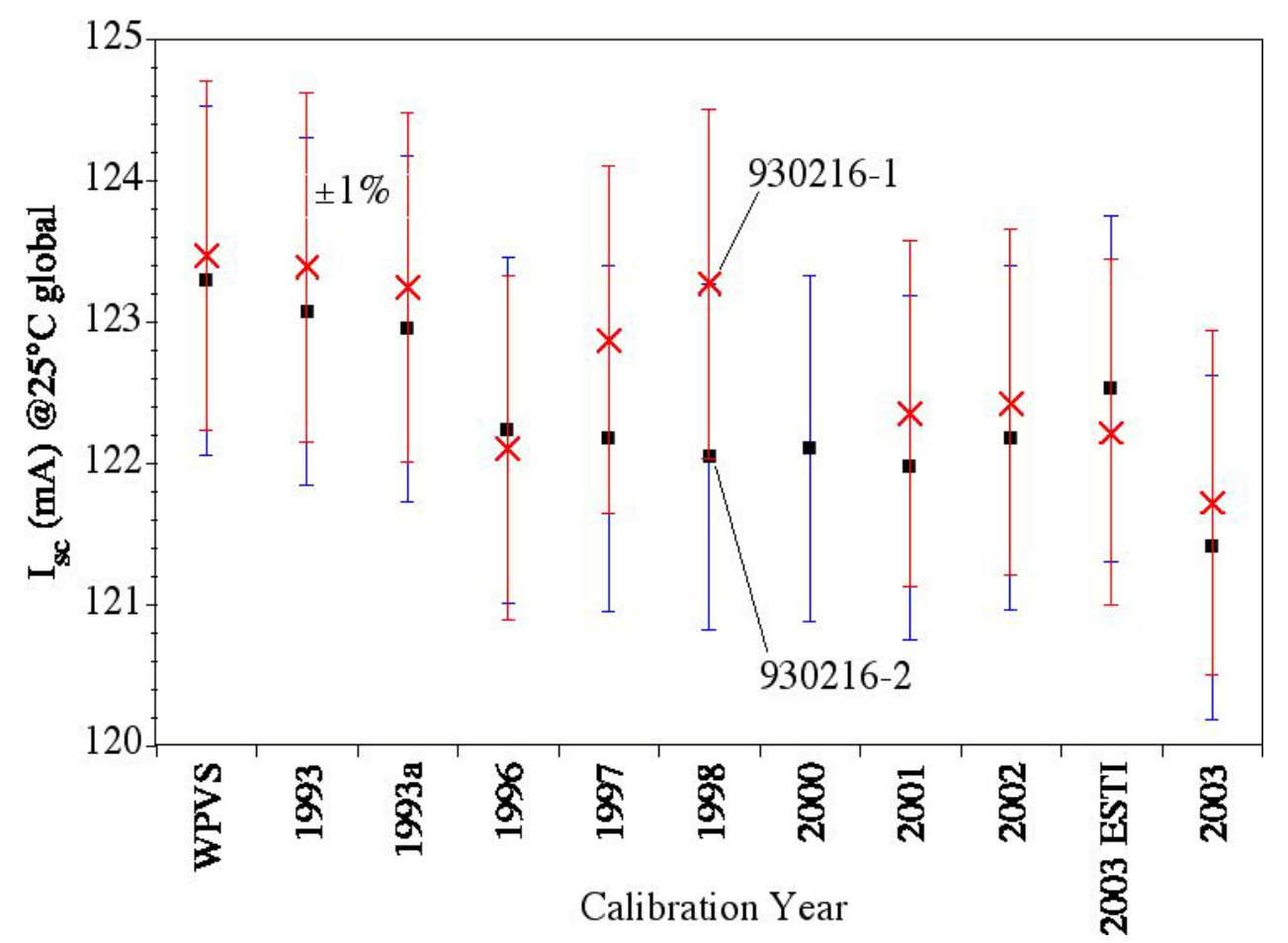

Figure 6. Calibration value measured at NREL compared with the WPVS average value of four international photovoltaic calibration laboratories including NREL.

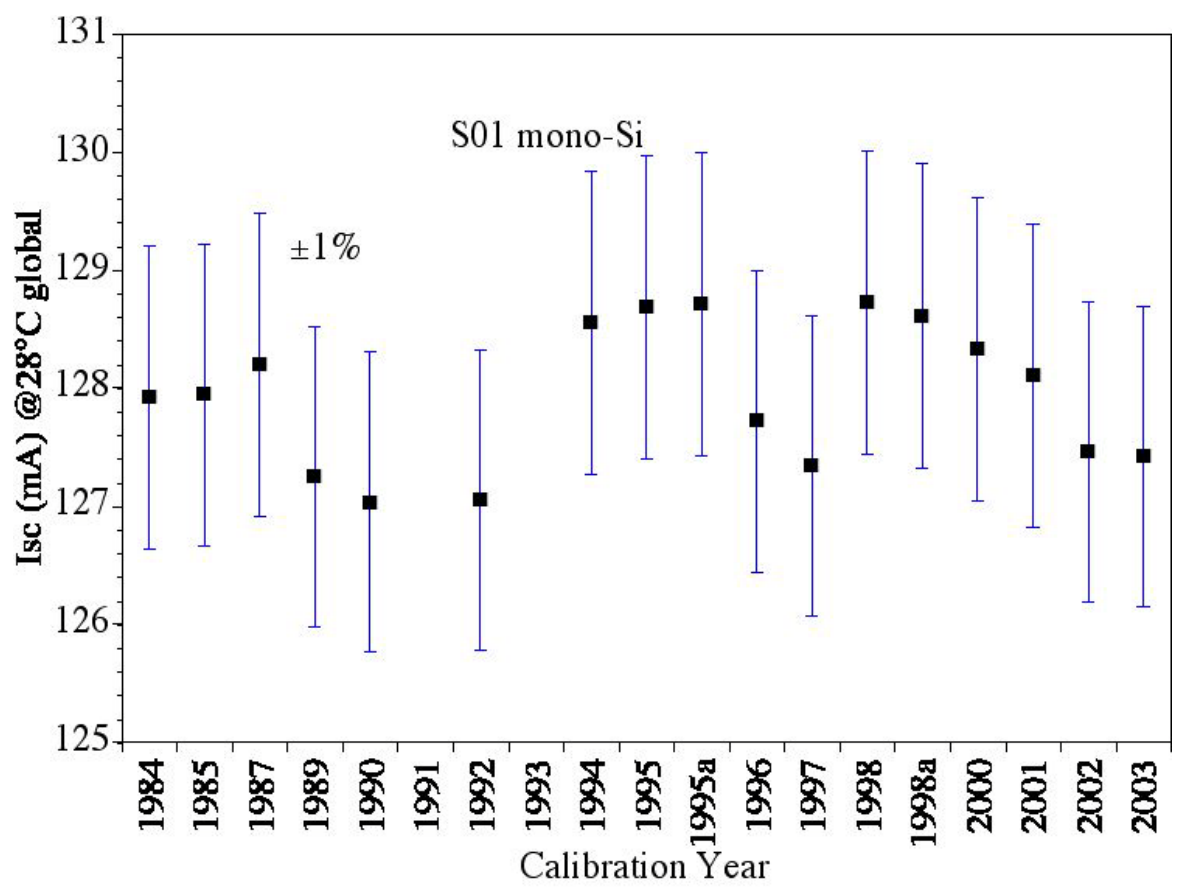

Figure 7. Nineteen years of primary reference cell calibrations on the same mono-Si cell. 


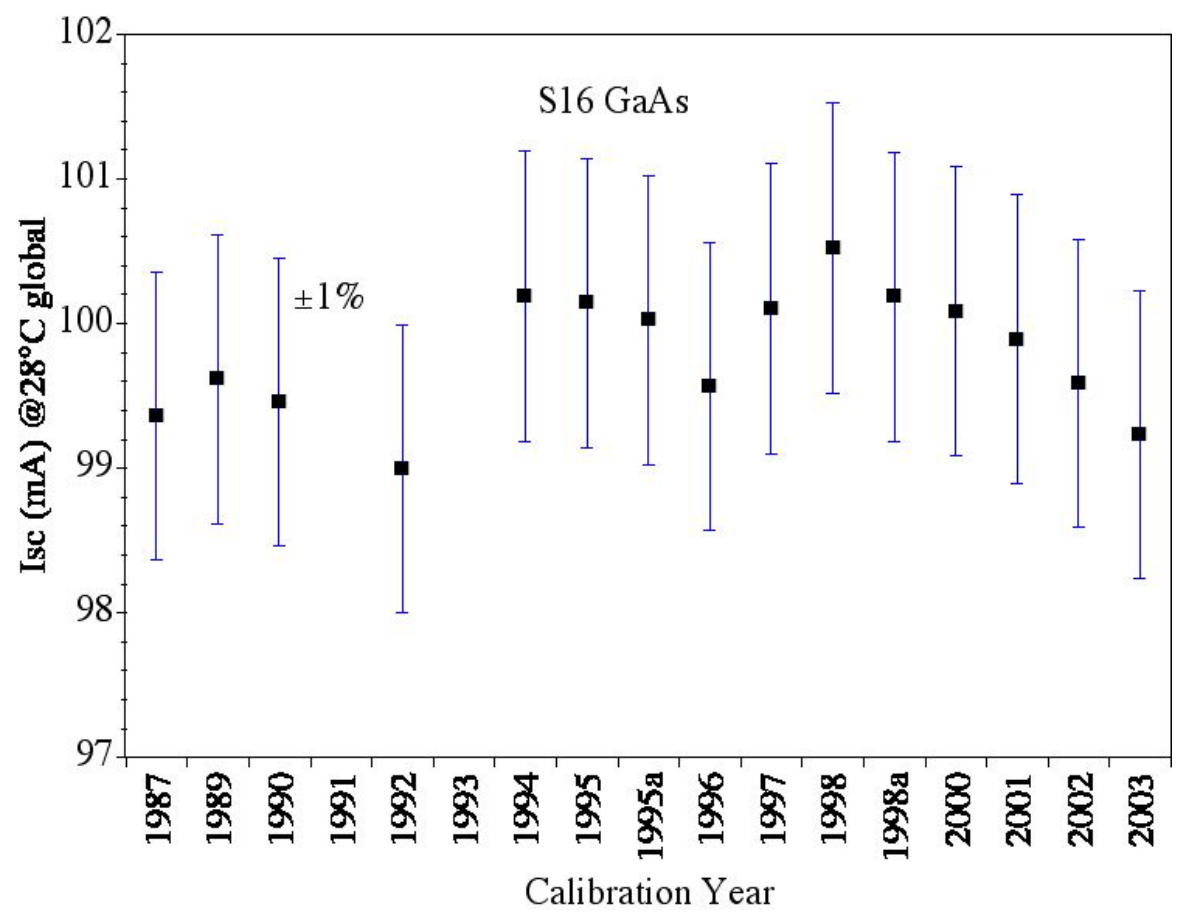

Figure 8. Seventeen years of primary reference cell calibrations on the same GaAs cell.

\section{References for Section 2}

1. ASTM Standard E1121, Standard Test Method for Calibration of Primary NonConcentrator Terrestrial Photovoltaic Reference Cells Using a Tabular Spectrum, Amer. Society for Testing Matls., West Conshocken PA, USA.

2. ASTM Standard 1040, Specification for Physical Characteristics of Non-Concentrator Photovoltaic Reference Cells, Amer. Society for Testing Matls., West Conshocken PA, USA.

3. ASTM Standard G159, Standard Tables for Reference Solar Spectral Irradiances: Direct Normal and Hemispherical on $37^{\circ}$ Tilted Surfaces, Amer. Society for Testing Matls., West Conshocken PA, USA.

4. ASTM Standard G73, Standard Tables for Reference Solar Spectral Irradiances: Direct Normal and Hemispherical on $37^{\circ}$ Tilted Surfaces, Amer. Society for Testing Matls., West Conshocken PA, USA.

5. K.A. Emery, C.R. Osterwald, T.W. Cannon, D.R. Myers, J. Burdick, T. Glatfelter, W. Czubatyj, and J. Yang, "Methods for Measuring Solar Cell Efficiency Independent of Reference Cell or Light Source," Proc. $18^{\text {th }}$ IEEE Photovoltaic Spec. Conf., Las Vegas, NV, October 21-25, 1985, pp.623-628, IEEE, New York, 1985.

6. C.R. Osterwald, (1986), Translation of Device Performance Measurements to Reference Conditions, Solar Cells 18, pp.269-279.

7. C.R. Osterwald, K.A. Emery, D.R. Myers, and C.J. Riordan, "Extending the Spectral Range of Silicon-Based Direct-Beam Solar Spectral Radiometric Measurements," Proc. $20^{\text {th }}$ IEEE Photovoltaic Specialists Conf., Las Vegas, NV, September 26-30, 1988, pp.1246-1250, IEEE, New York, 1989.

8. C.R. Osterwald, K.A. Emery, D.R. Myers, and R.E. Hart, "Primary Reference Cell Calibrations at SERI: History and Methods," Proc. $21^{\text {st }}$ IEEE Photovoltaic Specialists Conf., Orlando, FL, May 21-25, 1990, pp.1062-1067, IEEE, New York, 1990. 
9. K. A. Emery, C.R. Osterwald, S. Rummel, D.R. Myers, T.L. Stoffel, and D. Waddington, "A Comparison of Photovoltaic Calibration Methods," Proc. $9^{\text {th }}$ European Photovoltaic Solar Energy Conf., Freiburg, W. Germany, September 25-29, 1989, pp.648-651.

10. K.A. Emery, C.R. Osterwald, and C.V. Wells, "Uncertainty Analysis of Photovoltaic Efficiency Measurements," Proc. $19^{\text {th }}$ IEEE Photovoltaic Specialists Conf., New Orleans, LA, May 4-8, pp.153-159, IEEE, New York, 1987.

11. K.A. Emery, C.R. Osterwald, L.L. Kazmerski, and R.E. Hart, "Calibration of Primary Terrestrial References Cells When Compared with Primary AM0 Reference Cells," Proc. $8^{\text {th }}$ European Photovoltaic Solar Energy Conf., Florence, Italy, May 9-12, 1988, pp.64-68.

12. C. Osterwald and K. Emery, Spectroradiometric Sun Photometry," Journal of Atmospheric and Oceanic Technology 17, pp.1171-1188, 2000.

13. K.A. Emery, D. Waddington, S. Rummel, D.R. Myers, T.L. Stoffel, and C.R. Osterwald, SERI Results from the PEP 1987 Summit Round Robin and a Comparison of Photovoltaic Calibration Methods, SERI Tech. Rep. TR-213-3472, March 1989.

14. J. Metzdorf, T. Wittchen, K. Heidler, K. Dehne, R. Shimokawa, F. Nagamine, H. Ossenbrink, L. Fornarini, C. Goodbody, M. Davies, K. Emery, and R. Deblasio, "Objectives and Results of the PEP '87 Round-Robin Calibration of Reference Cells and Modules," Proc. $21^{\text {st }}$ IEEE Photovoltaic Specialists Conf., Orlando, FL, May 21-25, 1990, pp.952-959, IEEE, New York, 1990.

15. J. Metzdorf, T. Wittchen, K. Heidler, K. Dehne, R. Shimokawa, F. Nagamine, H. Ossenbrink, L. Fornarini, C. Goodbody, M. Davies, K. Emery, and R. Deblasio, "The Results of the PEP '87 Round-Robin Calibration of Reference Cells and Modules,- Final Report” PTB Technical Report PTB-Opt-31, Braunschweig, Germany, November 1990, ISBN 3-89429-067-6.

16. C.R. Osterwald, S. Anevsky, A.K. Barua, J. Dubard, K. Emery, D. King, J. Metzdorf, F. Nagamine, R. Shimokawa, N. Udayakumar, Y.X. Wang, W. Zaaiman, A. Zastrow, and J. Zhang, "Results of the PEP '93 Intercomparison of Reference Cell Calibrations and Newer Technology Performance Measurements," NREL Technical Report NREL/TP-520-23477, March 1998. Proc. 25 $5^{\text {th }}$ IEEE Photovoltaic Specialists Conf., Washington D.C., May 1317, 1996, pp.1263-1266, IEEE, New York, 1996.

17. C.R. Osterwald, S. Anevsky, A.K. Barua, J. Dubard, K. Emery, D. King, J. Metzdorf, F. Nagamine, R. Shimokawa, N. Udayakumar, Y.X. Wang, T. Wittchen, W. Zaaiman, A. Zastrow, and J. Zhang, "Results of the PEP'93 Intercomparison of Reference Cell Calibrations and Newer Technology Performance Measurements," Proc. $26^{\text {th }}$ IEEE PVSC Conf., Anaheim, CA. Sept. 29-Oct. 2, 1997, pp.1209-1212, IEEE, New York, 1997.

18. C.R. Osterwald, S. Anevsky, K. Bücher, A.K. Barua, P. Chaudhuri, J. Dubard, K. Emery, B. Hansen, D. King, J. Metzdorf, F. Nagamine, R. Shimokawa, Y.X. Wang, T. Witchen, W. Zaaiman, A. Zastrow, and J. Zhang, "The World Photovoltaic Scale: An International Reference Cell Calibration Program," Progress in Photovoltaics Research and Applications 7, pp.287-297, 1999.

19. K. Emery, "The Results of the First World Photovoltaic Scale Recalibration," NREL Tech. Rep. NREL/TP-520-27942, (March 2000).

20. ASTM Standard E 1341, Practice for Obtaining Spectroradiometric Data from Radiant Sources, Amer. Society for Testing Matls., West Conshocken PA, USA.

21. ASTM Standard E1021, Standard Test Methods for Measuring Spectral Response of Photovoltaic Cells, Amer. Society for Testing Matls., West Conshocken PA, USA.

22. "The Expression of Uncertainty and Confidence in Measurement," United Kingdom Accreditation Service, M3003, Middlesex, UK, December 1997. 
23. International Organization for Standardization, Guide to the Expression of Uncertainty in Measurement. ISO: Geneva, 1995, ISBN 92-67-10188-9.

24. I. Reda, "Calibration of a Solar Absolute Cavity radiometer with Traceability to the World radiometric Reference,” NREL Tech. Rep. NREL/TP-463-20619, January 1996.

25. I. Reda, 2002 NREL Pyrheliometer Comparisons (NPC-2002), Solar Radiation Research Laboratory, NREL.

26. H. Field and K. Emery, "An Uncertainty Analysis of the Spectral Correction Factor," Proc. $23^{\text {rd }}$ IEEE Photovoltaic Specialists Conf., Louisville, KY, May 10-14, 1993, pp.11801187, IEEE, New York, 1993.

27. K. Emery, "The Results of the First World Photovoltaic Scale Recalibration," NREL Tech. Rep. NREL/TP-520-27942, (March 2000). 


\subsection{UNCERTAINTY OF PHOTOVOLTAIC CELL SPECTRAL RESPONSIVITY}

\section{Reference to Norms and Standards}

- ASTM standard E1021, "Standard Test Methods for Measuring Spectral Response of Photovoltaic Cells"

- Procedure ISO GUM "International Organization for Standardization, Guide to the Expression of Uncertainty in Measurement. ISO: Geneva, 1995, ISBN 92-67-10188-9.

- ISO-VIM "International Vocabulary of Basic and General Terms in Metrology," $2^{\text {nd }}$ Edition 1993.

- ASTM standard E 1328 Terminology Relating to Photovoltaic Solar Energy Conversion"

\section{Summary}

This uncertainty analysis is for ASTM E1021, "Standard Test Methods for Measuring Spectral Response of Photovoltaic Cells" [1]. The analysis is restricted to single-junction monocrystal or multicrystal Si, GaAs, GaInP, GaInAs, Ge, or InP cells that are packaged with connectors [2]. Other technologies or unpackaged samples have additional error sources related to contacting, shading, and nonlinear behavior. This analysis is restricted to samples less than $4 \mathrm{~cm}^{2}$ in area. The calibration value of the PV reference cell is determined with respect to a reference temperature (typically $25^{\circ} \mathrm{C}$ ) and reference irradiance (typically ASTM G159 global [3], 1000 $\mathrm{W} / \mathrm{m}^{2}$ ). The PV Cell and Module Performance Characterization group has essentially been following these procedures since 1984 [4-17].

\section{Procedures}

The procedure from ASTM standard E1021 follows:

1. Calibrate the system by measuring the total power with a pyroelectric radiometer generating a file of power, $P(\lambda)$ versus wavelength $\lambda$.

2. Measure the responsivity of the reference detector.

3. Correct the calibration over the range of the reference detector, generating a corrected file of $P(\lambda)$ vs. $\lambda$ from the following equation:

$P(\lambda)=I^{R} / S_{\text {ref }}(\lambda)$

where:

$S_{\text {ref }}(\lambda) \quad$ Calibrated spectral responsivity of the reference detector in units of A/W $I^{R} \quad$ Measured current of the reference detector.

4. Verify that the calibration is valid by comparing the measured value of the reference detector with the calibrated value. Repeat steps 2 to 3 as needed.

5. Place the sample on the temperature control plate, which will maintain the temperature at $25^{\circ} \mathrm{C} \pm 2^{\circ} \mathrm{C}$.

6. Mount the sample with the connector into the input leads for the filter spectral response system. 
7. Select the wavelength range, measure the spectral responsivity, and save the normalized data $Q E(\lambda)$ versus $\lambda$ from the following equation:

$$
Q E(\lambda)=\frac{100 I^{T}}{\lambda \operatorname{Max}[Q E(\lambda)] P(\lambda)}
$$

where:

$I^{T} \quad$ Measured current of the device under test

$P(\lambda) \quad$ From Eq. 1 .

\section{Test Bed Specific Equipment}

Figure 9 is a simplified block diagram of the test bed.

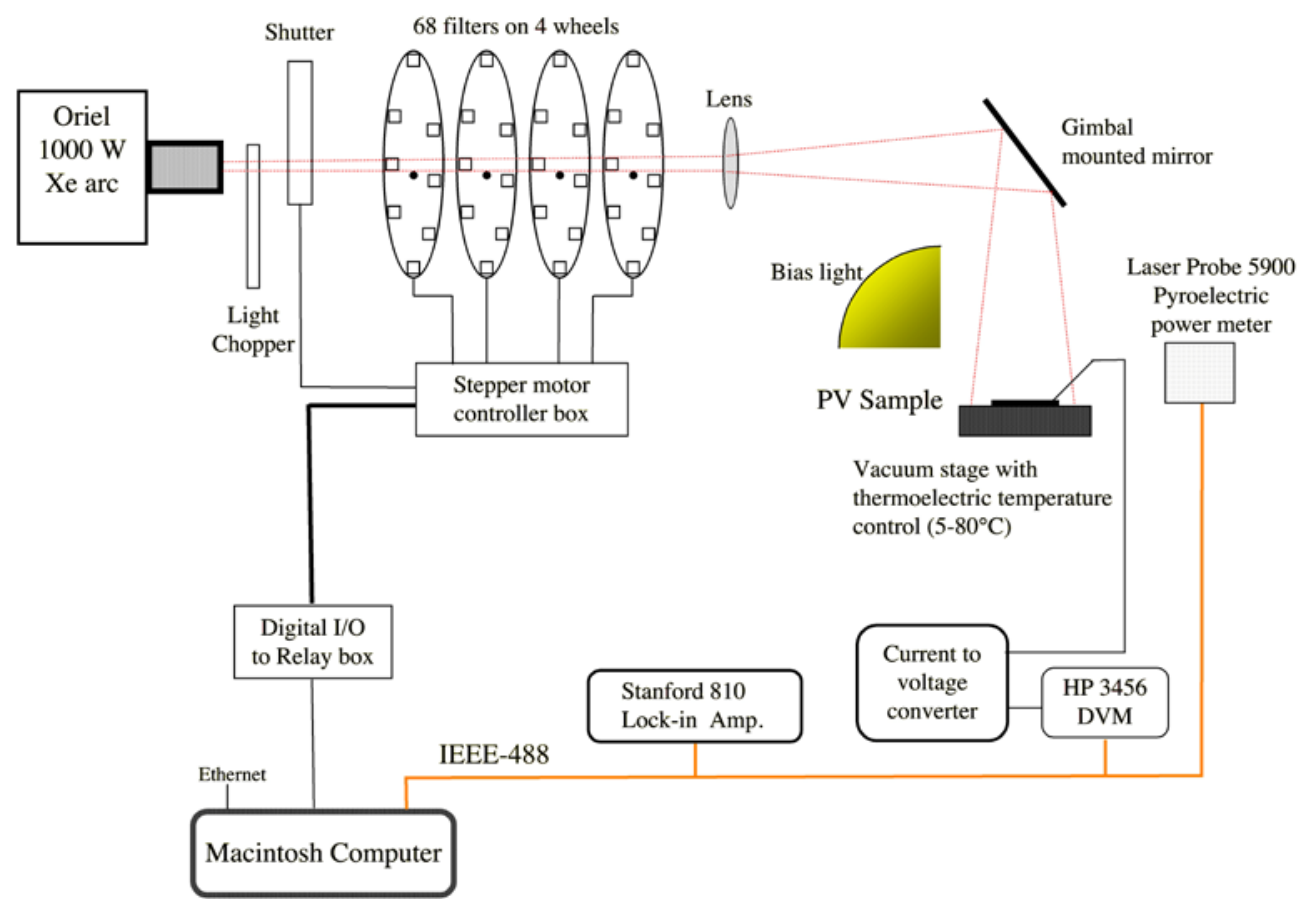

Figure 9. Filter quantum-efficiency system. This equipment is used to measure the quantum efficiency (QE) of a PV cell.

\section{Uncertainty in $Q E(\lambda)$ vs. $\lambda$}

Figure 10 is a plot of the typical quantum efficiency for a Si WPVS cell used in this study [4,5]. The numerous sources of uncertainty in determining $Q E(\lambda) v s$. $\lambda$ are documented in Refs. 6 and 7 and listed in Tables 2 to 4 . Since the data are normalized, any wavelength-independent multiplicative errors drop out. For the filter QE system and the Si cell in Fig. 10 the dominant error sources are the lamp intensity fluctuations, reference detector calibration uncertainty, spatial uniformity of the monochromatic light, and blocking of the light outside of the filter's pass band. The calibrated spectral responsivity $S_{\text {ref }}(\lambda)$ in Eq. 1 is obtained from NIST. Table 5 lists the detector measurement uncertainties from the NIST Web site of calibration services (http://ts.nist.gov/). 
The major error sources for the filter QE measurement system are listed in Table 6 as a percentage of the measured QE. The error from intensity fluctuations are both Type A and Type B. The reason is because the measurement is an average of ten readings, but since a stored calibration file is used, the intensity drift of the lamp with time during the generation of the calibration file and during the measurement is proportional to $I^{T}$. The reference detector uncertainty is a composite from Table 5. The spatial uniformity error exists because the spatial uniformity of the monochromatic beam is a function of wavelength and the reference detector and device under test are not exactly the same size. The filter blocking error can be estimated by assuming that the filters have no pinholes and that the $10-\mathrm{nm}$ bandwidth filters meet their specified blocking of $10^{-4}$ and integrating the power in the light source outside of the pass band. The error sources are larger for wavelengths less than $400 \mathrm{~nm}$ and near the energy gap (where the infrared quantum efficiency goes to zero). Combining the uncertainties in Table 6 gives

$$
\begin{aligned}
& U_{Q E}=2\left[\left(\frac{0.5}{\sqrt{10}}\right)^{2}+\left(\frac{2.0}{\sqrt{3}}\right)^{2}+\left(\frac{0.5}{2}\right)^{2}+\left(\frac{2.0}{\sqrt{3}}\right)^{2}+\left(\frac{2.0}{\sqrt{3}}\right)^{2}\right]^{0.5} \\
& U_{Q E}=4 \%
\end{aligned}
$$

This value is consistent with the observed $\sim 3 \%$ variation in the measured QE in Fig. 10, which should be a monotonically increasing then decreasing response.

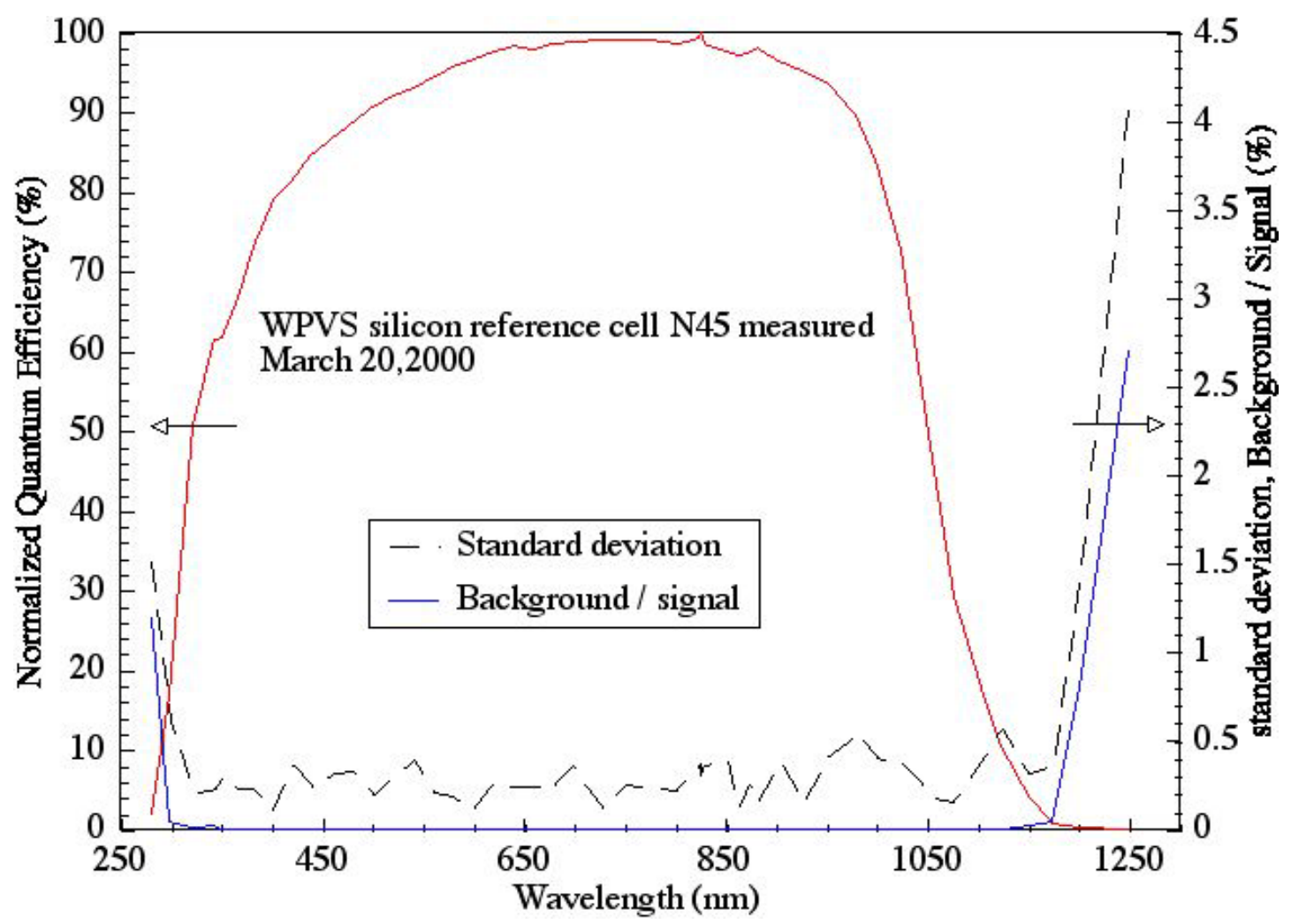

Figure 10. QE curve of WPVS reference cell N45 showing the standard deviation and signal-to-noise ratio. 
Table 2. Error Sources for Measurement of the Photocurrent

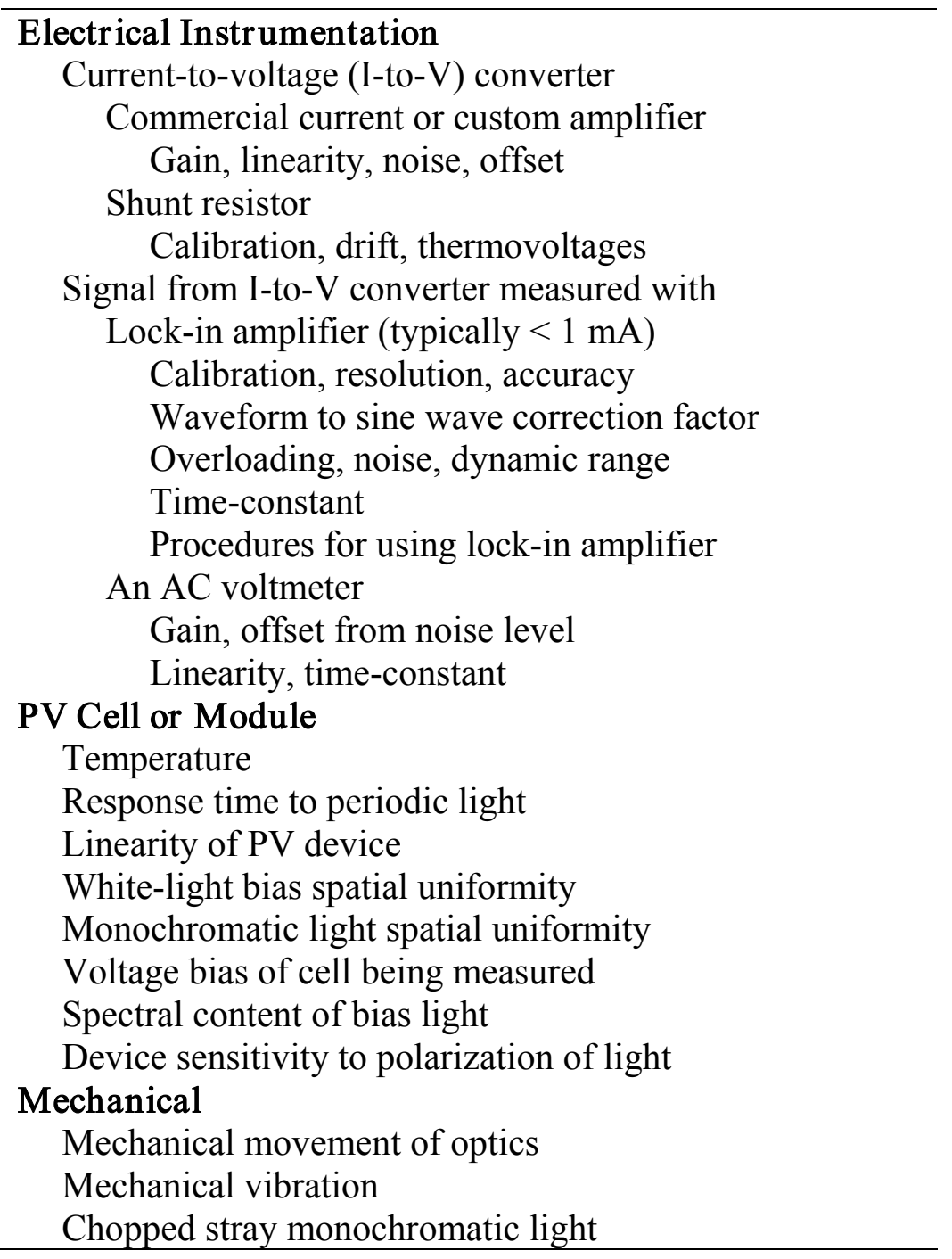




\author{
Filament or Xe-Arc Light Source \\ Intensity fluctuations \\ Change in spectrum with age and current \\ Stored Calibration File \\ Monochromatic source calibration drift with time \\ Stray Light \\ Detector sees light that cell does not see \\ Area of detector different from device area \\ Different field of views \\ Monochrometer \\ Incomplete attenuation of higher and \\ lower grating orders \\ Narrow-bandwidth filters \\ Pinholes in the filter \\ Degradation of blocking filter \\ Insufficient blocking $\left(\sim 10^{-4}\right)$ \\ Detectors and Associated Electronics in General \\ Calibration, resolution, accuracy \\ Gain, phase, offset, linearity \\ Spatial uniformity of detector element \\ Drift in temperature of room \\ Change in the detector's field of view \\ Degradation of detector \\ Spectral response of detector \\ Pyroelectric Detector \\ Time constant of detector \\ Microphonics, signal to noise \\ Phase-angle adjustment \\ Waveform factor (square wave assumed)
}

Table 4. Error Sources Related to the Monochromatic Light

Bandwidth
Filter Defects
Polarization Variation with Wavelength
Wavelength Offset, Error
Wavelength Variation with Room Temperature
Beam Wanders with Wavelength
Beam Larger than the Test Device
Detector area versus PV area
Position of detector and PV different
Spatial uniformity of beam
Beam Smaller than Detector and Device Area
Partially shaded regions
$\quad$ Spatial variation in responsivity of PV


Table 5. Detector Measurement Services Uncertainties Relative Expanded Uncertainty $(k=2)$

\begin{tabular}{|c|c|c|c|c|}
\hline $\begin{array}{l}\text { Wavelength } \\
{[\mathrm{nm}]}\end{array}$ & $\begin{array}{c}\text { UV } 100(\mathrm{UV}) \\
{[\%]}\end{array}$ & $\begin{array}{c}\text { S1337 (Visible) } \\
{[\%]}\end{array}$ & $\begin{array}{c}\text { GE (NIR) } \\
{[\%]}\end{array}$ & $\begin{array}{c}\text { InGaAs (NIR) } \\
{[\%]}\end{array}$ \\
\hline 200 & 3.8 & 3.8 & & \\
\hline 250 & 1.3 & 1.3 & & \\
\hline 300 & 1.3 & 1.3 & & \\
\hline 350 & 1.8 & 1.8 & & \\
\hline 400 & 1.5 & 1.5 & & \\
\hline 450 & 0.38 & 0.24 & & \\
\hline 500 & 0.38 & 0.22 & & \\
\hline 550 & & 0.20 & & \\
\hline 600 & & 0.20 & & \\
\hline 650 & & 0.20 & & \\
\hline 700 & & 0.20 & 0.46 & 0.38 \\
\hline 750 & & 0.22 & 0.42 & 0.36 \\
\hline 800 & & 0.22 & 0.68 & 0.54 \\
\hline 850 & & 0.22 & 0.44 & 0.44 \\
\hline 900 & & 0.22 & 0.50 & 0.40 \\
\hline 950 & & 2.6 & 1.2 & 1.3 \\
\hline 1000 & & 1.7 & 0.9 & 0.9 \\
\hline 1050 & & 2.7 & 0.9 & 0.9 \\
\hline 1100 & & 4.2 & 0.52 & 0.50 \\
\hline 1150 & & & 0.8 & 0.8 \\
\hline 1200 & & & 1.4 & 1.5 \\
\hline 1250 & & & 0.9 & 0.9 \\
\hline 1300 & & & 0.9 & 0.9 \\
\hline 1350 & & & 0.9 & 0.9 \\
\hline 1400 & & & 1.2 & 1.2 \\
\hline 1450 & & & 0.9 & 0.9 \\
\hline 1500 & & & 1.0 & 1.0 \\
\hline 1550 & & & 1.1 & 1.1 \\
\hline 1600 & & & 1.4 & 1.3 \\
\hline 1650 & & & 1.1 & 1.0 \\
\hline 1700 & & & 1.7 & 2.2 \\
\hline 1750 & & & 2.6 & 2.7 \\
\hline 1800 & & & 3.4 & 4.2 \\
\hline
\end{tabular}


Table 6. Major Errors Sources in Normalized Filter Quantum Efficiency Measurements

\begin{tabular}{llll}
\hline Source & $\begin{array}{l}\text { Type A Uncertainty } \\
\%\end{array}$ & $\begin{array}{l}\text { Type B Uncertainty } \\
\%\end{array}$ & $\begin{array}{l}\text { Coverage } \\
\text { \# Readings }\end{array}$ \\
\hline Intensity fluctuations & 0.5 & 2.0 & 10, Rectangular \\
Reference detector & - & 0.5 & Gaussian \\
Spatial uniformity & - & 2.0 & Rectangular \\
Filter blocking & - & 2.0 & Rectangular \\
& & & \\
\hline
\end{tabular}

\section{References for Section 3}

1. ASTM Standard E1021, Standard test methods for measuring spectral response of photovoltaic cells, Amer. Society for Testing Matls., West Conshocken PA, USA.

2. "The Expression of Uncertainty and Confidence in Measurement," United Kingdom Accreditation Service, M3003, Middlesex, UK, December 1997.

3. International Organization for Standardization, Guide to the Expression of Uncertainty in Measurement. ISO: Geneva, 1995, ISBN 92-67-10188-9.

4. C.R. Osterwald, S. Anevsky, A.K. Barua, J. Dubard, K. Emery, D. King, J. Metzdorf, F. Nagamine, R. Shimokawa, N. Udayakumar, Y.X. Wang, W. Zaaiman, A. Zastrow, and J. Zhang, "Results of the PEP '93 Intercomparison of Reference Cell Calibrations and Newer Technology Performance Measurements," NREL Technical Report NREL/TP-520-23477, March 1998. Proc. $25^{\text {th }}$ IEEE Photovoltaic Specialists Conf., Washington D.C., May 1317, 1996, pp.1263-1266, IEEE, New York, 1996.

5. C.R. Osterwald, S. Anevsky, A.K. Barua, J. Dubard, K. Emery, D. King, J. Metzdorf, F. Nagamine, R. Shimokawa, N. Udayakumar, Y.X. Wang, T. Wittchen, W. Zaaiman, A. Zastrow, and J. Zhang, "Results of the PEP'93 Intercomparison of Reference Cell Calibrations and Newer Technology Performance Measurements," Proc. $26^{\text {th }}$ IEEE PVSC Conf., Anaheim, CA. Sept. 29-Oct. 2, 1997, pp.1209-1212, IEEE, New York, 1997.

6. K.A. Emery, "Measurement and Characterization of Solar cells and Modules," Handbook of Photovoltaic Science and Engineering, Chap. 16, pp.701-747, A. Luque and S. Hegedus editors, John Wiley \& Sons, W. Sussex, U.K., ISBN 0-471-49196-9, 2003.

7. K. Emery, D. Dunlavy, H. Field, and T. Moriarty "Photovoltaic Spectral Responsivity Measurements," Proc. $2^{\text {nd }}$ World Conference and Exhibition on Photovoltaic Solar Energy Conversion, Vienna Austria July 6-10, 1998, Joint Research Center report EUR 18656, pp.2298-2301.

8. K.A. Emery, C.R. Osterwald, and C.V. Wells, "Uncertainty Analysis of Photovoltaic Efficiency Measurements," Proc. $19^{\text {th }}$ IEEE Photovoltaic Specialists Conf., New Orleans, LA, May 4-8, pp.153-159, IEEE, New York, 1987.

9. H. Field and K. Emery, "An Uncertainty Analysis of the Spectral Correction Factor," Proc. $23^{\text {rd }}$ IEEE Photovoltaic Specialists Conf., Louisville, KY, May 10-14, 1993, pp.11801187, IEEE, New York, 1993. 


\subsection{UNCERTAINTY OF ELECTRICAL PERFORMANCE OF PHOTOVOLTAIC CELLS}

\section{Reference to Norms and Standards}

- ASTM E948, "Standard Test Method for Electrical Performance of Photovoltaic Cells Using Reference Cells Under Simulated Sunlight." This procedure meets or exceeds the requirements in IEC standard 60904-1, "Photovoltaic Devices - Measurement of Photovoltaic Current-Voltage Characteristics."

- Procedure ISO GUM "International Organization for Standardization, Guide to the Expression of Uncertainty in Measurement. ISO: Geneva, 1995, ISBN 92-67-10188-9.

- ISO-VIM "International Vocabulary of Basic and General Terms in Metrology," $2^{\text {nd }}$ Edition 1993.

- ASTM standard E 1328 Terminology Relating to Photovoltaic Solar Energy Conversion"

\section{Summary}

This uncertainty analysis is for ASTM E948, "Standard Test Method for Electrical Performance of Photovoltaic Cells Using Reference Cells Under Simulated Sunlight" [1]. The analysis is restricted to single-junction monocrystal or multicrystal Si, GaAs, GaInP, GaInAs, Ge, or InP cells that are packaged with connectors [2]. Other technologies or unpackaged samples have additional error sources related to contacting and a larger spectral mismatch correction. This analysis is restricted to samples less than $100 \mathrm{~cm}^{2}$ in area. The current versus voltage (I-V) characteristics are measured within $2^{\circ} \mathrm{C}$ of the reference temperature (typically $25^{\circ} \mathrm{C}$ ) and within $2 \%$ of the reference irradiance (typically ASTM G159 global [3], $1000 \mathrm{~W} / \mathrm{m}^{2}$ ). Using ASTM G173 global [4] gives essentially the same uncertainty because the spectra are nearly identical affecting the $I_{s c}$ for Si cells less than $1 \%$. The international equivalent of these spectra are IEC standard 60904-3 editions 1 and 2. Our group has essentially been following these procedures since 1984 [9-14]. To simplify matters, the uncertainties of the input quantities are expressed in terms of percentage of value. Since all equations are or will be reduced to multiplications and divisions, the sensitivity coefficient reduces to unity. The uncertainty of the performance parameters will then be same for similar cells.

\section{Procedures}

The procedure from E948 follows:

1. Measure the cell area, $A$, using the definition in Terminology E 1328 [5].

2. Measure the relative spectral responsivity of the PV cell to be calibrated using Test Method E1021 [6].

3. Choose a primary reference cell.

4. Determine the spectral mismatch parameter, $M$, using Test Method E $973[7,9,10]$. 


$$
M=\frac{\int_{\lambda_{1}}^{\lambda_{2}} E_{S}(\lambda) S_{t}(\lambda) \mathrm{d} \lambda \lambda \int_{\lambda_{3}}^{\lambda_{4}} E_{r e f}(\lambda) S_{r}(\lambda) \mathrm{d} \lambda}{\lambda_{\lambda_{3}} E_{S}(\lambda) S_{r}(\lambda) \mathrm{d} \lambda \int_{\lambda_{1}}^{\lambda_{2}} E_{r e f}(\lambda) S_{t}(\lambda) \mathrm{d} \lambda}
$$

where:

$S_{t}(\lambda) \quad$ Measured spectral responsivity of the test cell (Test Method E1021 [8])

$S_{r}(\lambda) \quad$ Measured spectral responsivity of the reference cell (Test Method

$E_{S}(\lambda) \quad$ Measured spectral irradiance of the light source (Test method E973 [7])

$\lambda_{1}, \lambda_{2}, \lambda_{3}, \lambda_{4} \quad$ Wavelength limits of integration.

5. Mount the reference cell in the center of the test plane and verify that the plate temperature or reference cell temperature are within $\pm 2^{\circ} \mathrm{C}$ of the temperature corresponding to the reference cell short-circuit current calibration value, $I_{R R}$.

6. Adjust the simulator so that the measured reference cell short-circuit current $I_{R M}$ is within $2 \%$ of the spectrally corrected calibration value or

$$
0.98 \leq\left(I_{R R} / M\right) / I_{R M} \leq 1.02
$$

7. Transfer this value to an intensity monitor giving a calibration value for the intensity monitor by recording the average of at least ten measurements of the following equation:

$$
I_{M R}=\left(I_{M M} I_{R R}\right) /\left(M I_{R M}\right),
$$

where:

IMR Calibrated short-circuit current of the intensity monitor located near the edge of the test plane.

$I_{M M} \quad$ Measured short-circuit current of the intensity monitor located near the edge of the test plane.

8. Mount the cell to be tested on the temperature-controlled plate in the same position as the reference cell and adjust the plate temperature so the cell is within $2^{\circ} \mathrm{C}$ of the reference temperature.

9. Measure the open-circuit voltage, $V_{o c}$, with the load disconnected.

10. Measure the current versus voltage ( $I_{T M}, V$ characteristic of the cell under test by changing the operating point with the variable load so that the curve is swept through $0 \mathrm{~V}$ and $0 \mathrm{~A}$. At each operating point on the $\left(I_{T M}, V\right)$ characteristic, measure the cell voltage, $V$, cell current, $I_{T M}$, and $I_{M M}$. Correct the measured current, $I_{T M}$, for intensity fluctuations, giving 
the calibrated current of the test cell under the reference spectrum at the reference irradiance and temperature, $I_{T R}$, using

$$
I_{T R}=I_{T M} I_{M R} / I_{M M}
$$

11. Measure the open-circuit voltage, $V_{o c}$, with the load disconnected.

12. Determine the calibrated $I_{s c}$ by performing a linear-regression fit to all $I_{T R} V$ points that satisfy the constraint that all currents are within $4 \%$ of the current at $0 \mathrm{~V}$ and of all voltages within 0.20 times the voltage at $0 \mathrm{~A}$.

13. Determine the maximum power, $\mathrm{P}_{\max }$, by performing a polynomial fit to all $\mathrm{I}_{\mathrm{TR}}-\mathrm{V}$ points that satisfy the constraints that the measured power is within $85 \%$ of the largest measured power and the voltage is within $80 \%$ of the voltage at the largest measured power as recommended by E948. The polynomial that gives the best fit to the data up to a fifth order is used. The voltage at maximum power, $V_{\max }$, is the real root of the derivative of the fit of the power versus voltage polynomial set to 0 . This voltage is then substituted into the power vs. voltage polynomial to obtain the $P_{\max }$. The current at maximum power, $I_{\max }$, is calculated from $P_{\max } / V_{\max }$

14. The current vs. voltage data points, $\left(I_{T R}, V\right.$, along with a variety of information including $V_{o c}, I_{s c}, P_{\max }$, temperature, time, cell ID, cell type, manufacturer, reference cell, and its calibration, the record book number and page, change in $V_{o c}$ before and after the measurement, are saved.

\section{Test-Bed-Specific Equipment}

Figure 11 is a photograph of the test bed.

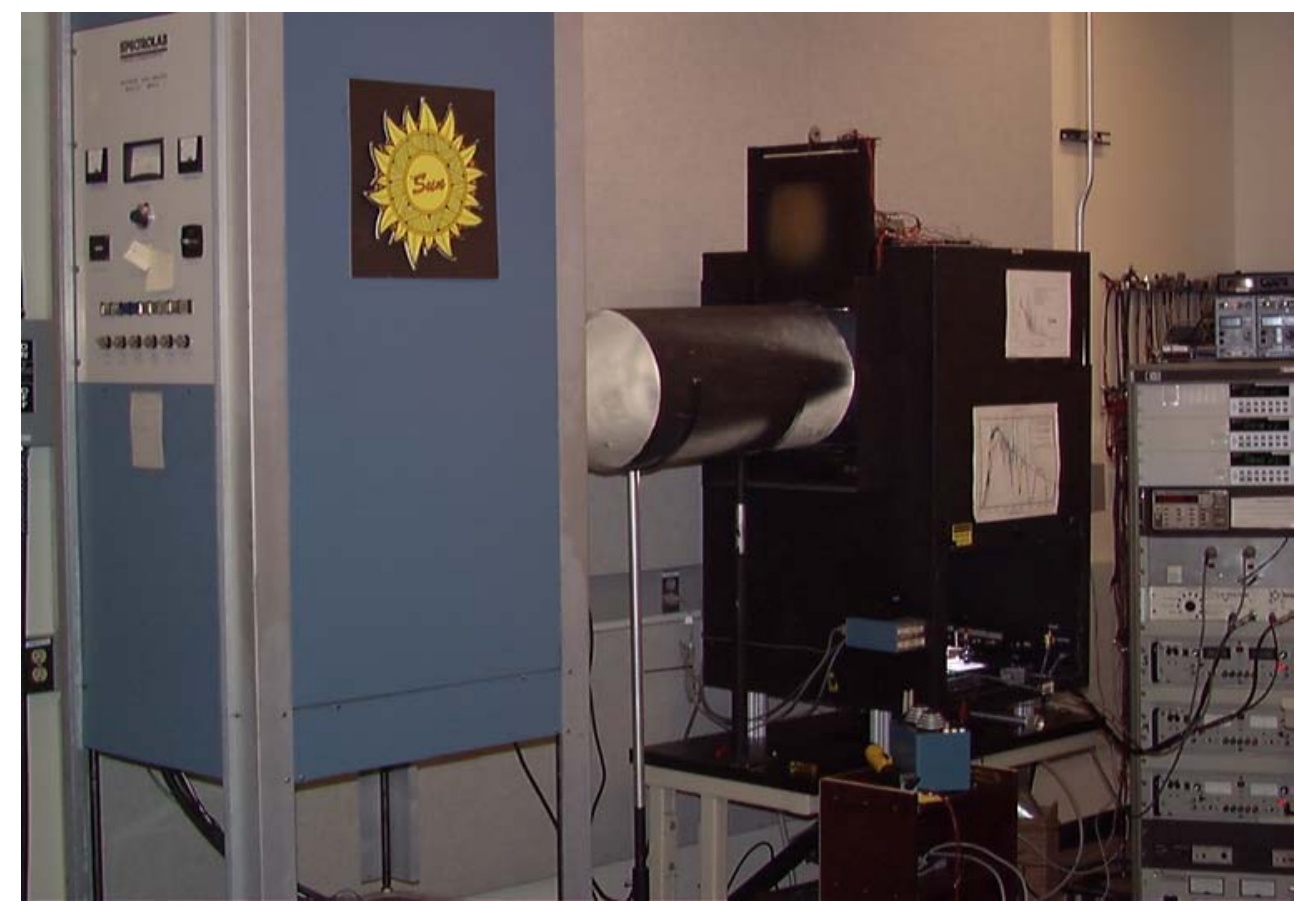

Figure 11. The Spectrolab X25 solar simulator and custom I-V measurement system. 
Figure 12 is a simplified block diagram of the test bed.

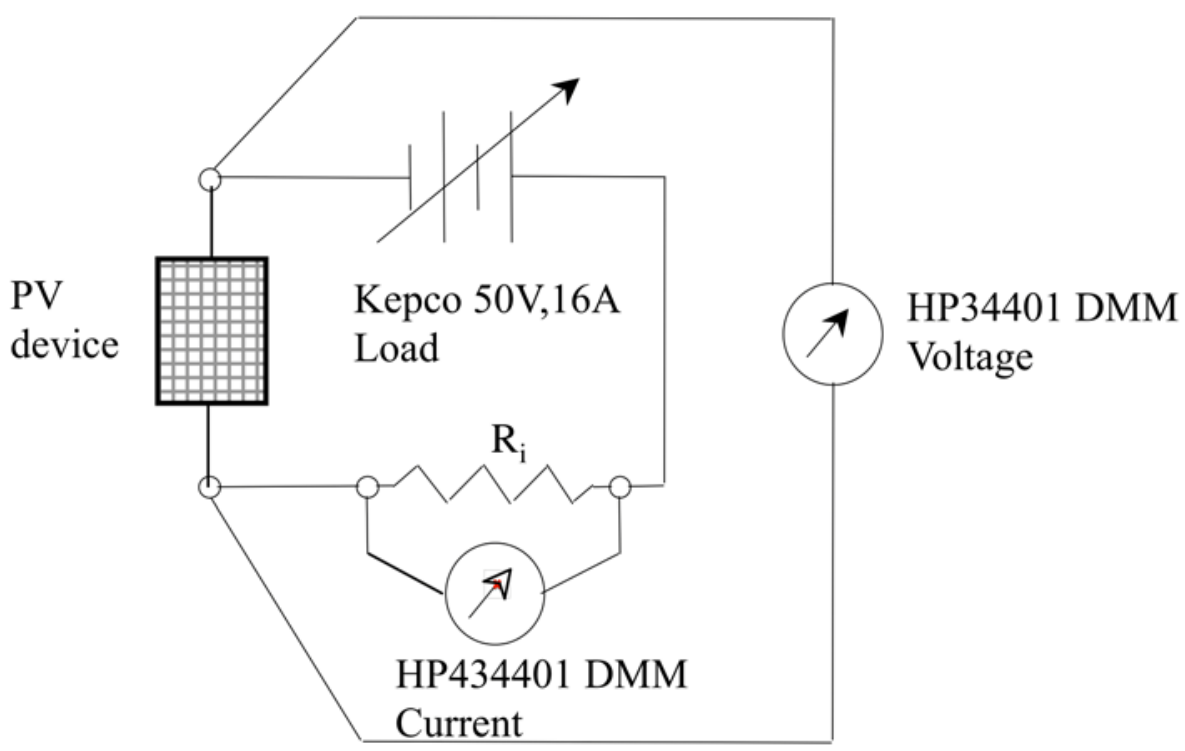

Figure 12. Simplified block diagram of current versus voltage test station.

\section{Uncertainty Analysis}

Table 7 summarizes the standard uncertainty components. All uncertainty components are given in percentage with a typical $2-\mathrm{cm}$ by $2-\mathrm{cm} \mathrm{Si} \mathrm{cell} \mathrm{as} \mathrm{the} \mathrm{reference} \mathrm{case.}$

Table 7. Summary of Standard Secondary Reference Cell Uncertainty Components

\begin{tabular}{llll}
\hline $\begin{array}{l}\text { Uncertainty } \\
\text { Component }\end{array}$ & \multicolumn{1}{c}{ Source of Uncertainty } & $\begin{array}{c}\text { Value of } \\
\text { Uncertaint } \\
\text { y (\%) }\end{array}$ & $\begin{array}{c}\text { Coverage } \\
\text { Factor }\end{array}$ \\
\hline$U_{M-D M M}$ & Intensity Monitor meter (25 mV typical value) & $\mathbf{0 . 0 1 3}$ & Rectangular \\
\hline & 1-year HP34401, 1 V, of reading & 0.004 & Rectangular \\
\hline & 1-year HP34401, 1 V, of range & 0.0007 & Rectangular \\
\hline & 1-year HP34401, 1 V, 1 line cycle & 0.001 & Rectangular \\
\hline & HP34401, 1 V, temperature $23 \pm 15{ }^{\circ} \mathrm{C}$ & 0.0075 & Rectangular \\
\hline$U_{M M}, U_{M M}$, & Measured Monitor current & $\mathbf{0 . 0 2 5}$ & Gaussian \\
\hline & $\begin{array}{l}\text { 1-year resistor stability (Julie } \mathrm{CH}-48 \mathrm{~T} 4 \text { data } \\
\text { sheet) }\end{array}$ & 0.003 & Gaussian \\
\hline & 1-year resistor calibration uncertainty & 0.02 & Gaussian \\
\hline Resistor temperature $0.0005 \% /{ }^{\circ} \mathrm{C} \cdot 15^{\circ} \mathrm{C}$ & 0.075 & Gaussian \\
\hline$U_{R-D M M}$ & $\begin{array}{l}\text { Reference cell DMM }(130 \mathrm{~mA} \text { typical value, } 10 \Omega \\
\text { current sense) }\end{array}$ & $\mathbf{0 . 0 1 6}$ & \\
\hline 1-year HP34401, 10 V, of reading & 0.005 & Rectangular \\
\hline 1-year HP34401, 10 V, of range & 0.0007 & Rectangular \\
\hline
\end{tabular}




\begin{tabular}{|c|c|c|c|}
\hline $\begin{array}{l}\text { Uncertainty } \\
\text { Component }\end{array}$ & Source of Uncertainty & $\begin{array}{c}\text { Value of } \\
\text { Uncertaint } \\
\mathrm{y}(\%)\end{array}$ & $\begin{array}{l}\text { Coverage } \\
\text { Factor }\end{array}$ \\
\hline & 1-year HP34401, $10 \mathrm{~V}, 1$ line cycle & 0.001 & Rectangular \\
\hline & HP34401, $10 \mathrm{~V}$, temperature $23 \pm 15^{\circ} \mathrm{C}$ & 0.0075 & Rectangular \\
\hline \multirow[t]{4}{*}{$U_{R M}$} & Measured reference cell current & 0.027 & Gaussian \\
\hline & 1-year resistor stability (Julie CH-48T4 data sheet) & 0.003 & Gaussian \\
\hline & 1-year calibration uncertainty & 0.02 & Gaussian \\
\hline & Resistor temperature $0.0005 \% /{ }^{\circ} \mathrm{C}$ & 0.0225 & Gaussian \\
\hline \multirow[t]{5}{*}{$U_{I-D M M}$} & Test device current DMM (130 mA typical value) & 0.021 & Gaussian \\
\hline & 1-year HP34401, $1 \mathrm{~V}$, of reading & 0.004 & Gaussian \\
\hline & 1-year HP34401, $1 \mathrm{~V}$, of range & 0.0007 & Gaussian \\
\hline & 1-year HP34401, 1 V, 1 line cycle & 0.001 & Gaussian \\
\hline & $\mathrm{HP} 34401,100 \mathrm{mV}$, temperature $23 \pm 15^{\circ} \mathrm{C}$ & 0.0075 & Gaussian \\
\hline \multirow[t]{4}{*}{$U_{T M}$} & $\begin{array}{l}\text { Measured test cell current (Riedon PF1121 }<5 \mathrm{~A} \text {, } \\
\text { Riedon PF1328 }>5 \mathrm{~A} \text { ) }\end{array}$ & $\begin{array}{l}0.038 \\
0.11\end{array}$ & Gaussian \\
\hline & $\begin{aligned} 1 \text {-year resistor stability } & \text { Riedon PF1121 } \\
& \text { Riedon PF1328 }\end{aligned}$ & $\begin{array}{l}0.01 \\
0.1\end{array}$ & Gaussian \\
\hline & 1-year resistor calibration uncertainty & 0.02 & Gaussian \\
\hline & Resistor temperature $0.0015 \% /{ }^{\circ} \mathrm{C}$ & 0.0225 & Gaussian \\
\hline$U_{T T}$ & Test cell current for $\pm 1^{\circ} \mathrm{C}$ & 0.05 & Rectangular \\
\hline$U_{T R}$ & Reference cell current for $\pm 1^{\circ} \mathrm{C}$ & 0.05 & Rectangular \\
\hline$U_{R R}$ & Primary reference cell Calibration value & 0.91 & Rectangular \\
\hline$R_{C}$ & $\begin{array}{l}\text { Least-squares fit standard deviation for } \mathrm{I}_{\mathrm{TR}}\left(\mathrm{I}_{\mathrm{sc}} \text { of }\right. \\
\text { test cell) }\end{array}$ & 0.03 & $\mathrm{~N}=15$ \\
\hline$R_{T}$ & $\begin{array}{l}\text { Reference cell } \mathrm{I}_{\mathrm{sc}} \text { to monitor } \mathrm{I}_{\mathrm{sc}} \text { transfer standard } \\
\text { deviation }\end{array}$ & 0.02 & $\mathrm{~N}=125$ \\
\hline$U_{S}$ & Error from spatial nonuniformity & 0.5 & Rectangular \\
\hline$U_{M}$ & Error in the spectral correction factor $\mathrm{M}$ & 0.4 & Gaussian \\
\hline$U_{I S c}$ & Uncertainty in test cell $\mathrm{I}_{\mathrm{sc}}$ & 1.27 & coverage $=2$ \\
\hline$U_{P \text {-fit }}$ & Error in $\mathrm{P}_{\max }$ from the fit & 0.06 & Gaussian \\
\hline$U_{T V}$ & Test cell voltage for $\pm 1^{\circ} \mathrm{C}$ & 0.5 & Rectangular \\
\hline$U_{V}$ & Measured test cell voltage & 0.006 & Rectangular \\
\hline$U_{\operatorname{Vmax}}$ & Maximum power voltage & 0.7 & coverage $=2$ \\
\hline$U_{\text {Imax }}$ & Maximum power current & 1.4 & coverage $=2$ \\
\hline$U_{P \max }$ & Maximum power & 1.40 & coverage $=2$ \\
\hline$U_{V o c}$ & Open-circuit voltage & 0.58 & coverage $=2$ \\
\hline$U_{A}$ & Area & 1.20 & coverage $=2$ \\
\hline$U_{\eta}$ & Efficiency & 1.84 & coverage $=2$ \\
\hline$U_{F F}$ & Fill factor (from $U_{\text {Voc }}, U_{I s c}, U_{P \operatorname{Pax}}$ ) & 1.97 & coverage $=2$ \\
\hline$U_{F F}$ & $\begin{array}{l}\text { Fill factor - more rigorous neglecting intensity } \\
\text { errors }\end{array}$ & 0.58 & coverage $=2$ \\
\hline
\end{tabular}




\subsection{Uncertainty in $I_{s c}$}

The uncertainty in the short-circuit current of the reference cell, $I_{T R}$ from Eq. 4 , is determined using standard uncertainty analysis based on $[22,23]$. For convenience, the elemental Type A and Type B error sources will be expressed in terms of percentage of value. The analysis is based on the best measurement capability and represents the smallest uncertainty of nearly ideal PV reference cells. This means that the cells should be stable with no measurable degradation, packaged with wires and temperature sensors, and close to $2 \mathrm{~cm}$ by $2 \mathrm{~cm}$ in area. Combining Eqs. 3 and 4 yields

$$
I_{T R}=\left(I_{T M} I_{M M}, I_{R R}\right) /\left(M I_{R M} I_{M M}\right)
$$

To express the uncertainty as a percentage, a typical I-V case is used so that the voltmeter range and resolution can be converted to a percentage. Figure 13 is the I-V curve for the typical case.

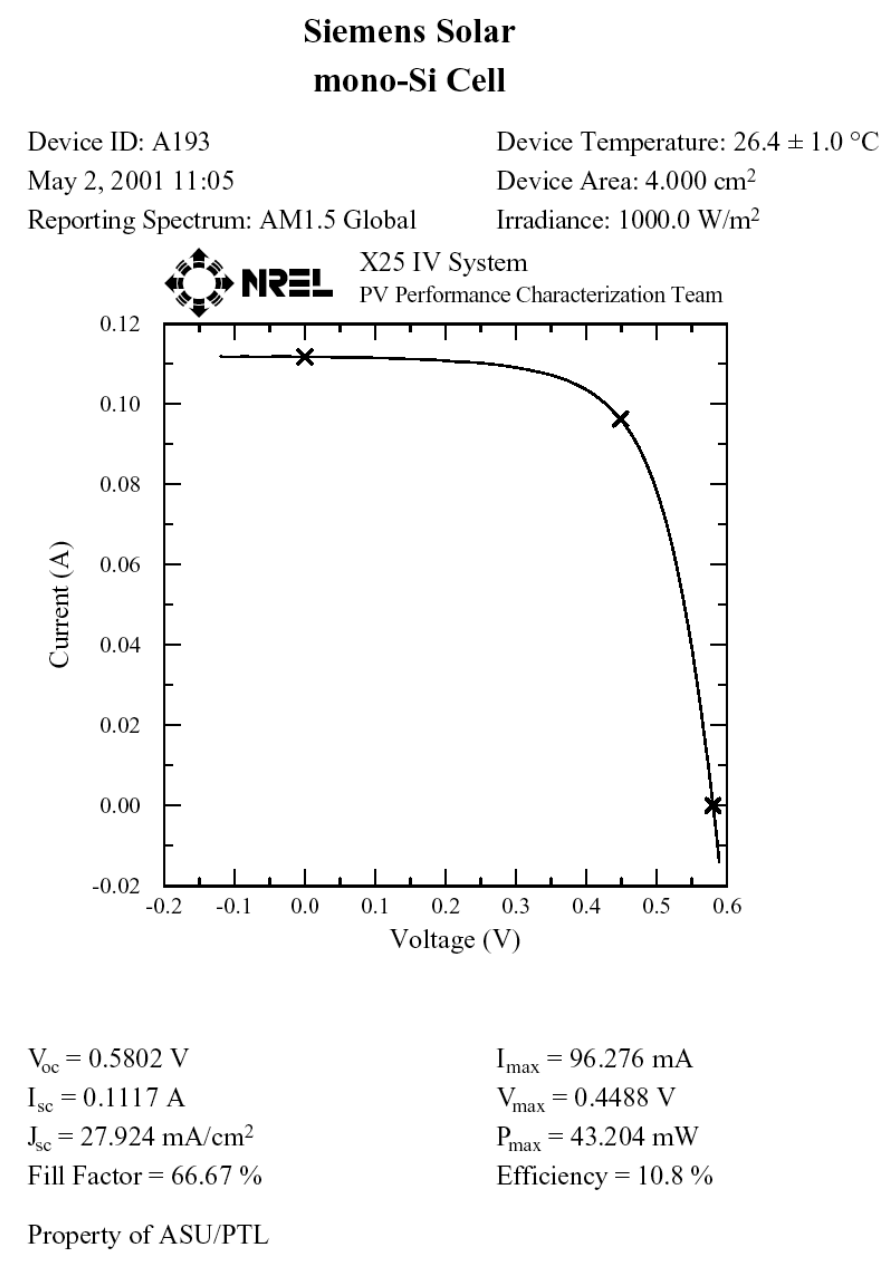

Figure 13. Typical I-V curve for a reference cell.

The measured monitor value $I_{M M}$, or $I_{M M}$ is the voltage measured across a 10 -ohm resistor with an Agilent 34401A multimeter with 1-power-line cycle integration period. The measured monitor voltage is typically $250 \mathrm{mV}$. An op-amp circuit is used to bias the monitor cell within $2 \mathrm{mV}$ of zero volts and monitor the current with a 10-ohm 4-terminal resistor (Appendix 2). From the 1-year manufacturer's specification, the uncertainty on the Agilent 34401A voltmeter 
$1-\mathrm{V}$ range is $0.0040 \%$ of the reading plus $0.0007 \%$ of the range plus $0.001 \%$ of range because the power line cycle was not longer than 1 . The distribution is assumed to be rectangular because the data sheet does not specify the confidence value. The meter uncertainties supplied by the manufacturer are based on a $23 \pm 5^{\circ} \mathrm{C}$ operating temperature. Since the resistors and meters are in a temperature-controlled room at $23 \pm 15^{\circ} \mathrm{C}$, the maximum expected resistor and meter temperature deviation is $23 \pm 15^{\circ} \mathrm{C}$. The temperature coefficient of the meter outside of the $23 \pm 15^{\circ} \mathrm{C}$ is $0.0005 \% /{ }^{\circ} \mathrm{C}$ of the reading and $0.0001 \% /{ }^{\circ} \mathrm{C}$ of the range for the $1-\mathrm{V}$ range. The total error of the voltage reading across the 1-ohm current sense resistor $U_{M-D M M}$ is

$$
\begin{gathered}
U_{M-D M M}=[\% \text { of reading }+ \text { temperature correction }]+[\% \text { of range }+ \text { temperature correction }]= \\
100 \cdot\{[(0.0007+15 \cdot 0.0005) \cdot 0.01 \cdot 0.25]+ \\
[(0.0040+15 \cdot 0.0001+0.001) \cdot 0.01 \cdot 1]\} / 0.25 \mathrm{~V}=0.013 \% .
\end{gathered}
$$

The temperature coefficient of the 10-ohm resistor manufactured by Julie Research Laboratory model $\mathrm{CH}-48 \mathrm{~T} 4$ (now manufactured by $\mathrm{Ohm}-\mathrm{Labs}$ ) is $5 \mathrm{ppm} /{ }^{\circ} \mathrm{C}$ or $0.0005 \% /{ }^{\circ} \mathrm{C}$. The uncertainty of the $10-\mathrm{ohm}$ resistor calibration at NREL is $0.02 \%$. The 1-year stability of the resistor is taken as $0.003 \%$ /year from the data sheet. The power rating of the resistor is $6 \mathrm{~W}$ and the power dissipated across the resistor is $\left(10 \mathrm{ohm} \cdot 0.0252 \mathrm{~A}^{2}=6 \mathrm{~mW}\right)$, so resistor heating is negligible. Hence, $U_{M M}$ and $U_{M M}$, the uncertainties in $I_{M M}$ and $I_{M M}$, respectively taken to be

$$
\begin{aligned}
U_{M M}, & U_{M M^{\prime}}=\left[\left(U_{M-D M M}\right)^{2}+\left(T_{\text {resistor }} \cdot T_{\text {coeficient-resistor }}\right)^{2}+\left(U_{\text {resistor }}\right)^{2}+\left(U_{\text {stability }}\right)^{2}\right]^{0.5} \\
& =\left[(0.013 \%)^{2}+(15 \cdot 0.005)^{2}+(0.02)^{2}+(0.003)^{2}\right]^{0.5} \\
& =0.025 \% .
\end{aligned}
$$

The distribution is taken to be rectangular in the absence of further information.

The primary reference cell measured short-circuit current $I_{R M}$ is the voltage measured across a 10-ohm resistor with an Agilent 34401A multimeter with 1-power-line cycle integration period. The circuit used to bias the reference cell within $2 \mathrm{mV}$ of $0 \mathrm{~V}$ is described in Appendix 2. The reference cell current at standard reporting conditions (SRC) is typically $130 \mathrm{~mA}$. From the 1year manufacturer's specification, the uncertainty on the $10-\mathrm{V}$ range is $0.0035 \%$ of the reading plus $0.0005 \%$ of the range plus $0.001 \%$ of the range because the power-line cycle was not longer than 1 . The meter uncertainties are based on a $23 \pm 15^{\circ} \mathrm{C}$ operating temperature. The total error of the reference cell voltage reading $U_{R-D M M}$ is

$$
\begin{aligned}
& U_{R-D M M}=[\% \text { of reading }+ \text { temperature correction }]+[\% \text { of range }+ \text { temperature correction }]= \\
& 100 \cdot\{[(0.0035+15 \cdot 0.0005) \cdot 0.01 \cdot 1.30]+ \\
& \\
& \quad[0.0005+(15 \cdot 0.0001+0.001) \cdot 0.01 \cdot 10]\} / 1.30 \\
& \quad=0.008 \%
\end{aligned}
$$

The uncertainty of the 10 -ohm resistor calibrated at NREL is $0.02 \%$ with $95 \%$ confidence level. The Julie resistor temperature coefficient is negligible at $5 \mathrm{ppm} /{ }^{\circ} \mathrm{C}=0.0005 \% /{ }^{\circ} \mathrm{C}$. The 1 -year stability of the resistor is taken as $20 \mathrm{ppm} /$ year because the resistors have been in use for more than 10 years. The power rating of the resistor is $6 \mathrm{~W}$ and the power dissipated across the resistor is $\left(10 \mathrm{ohm} \cdot 0.132 \mathrm{~A}^{2}=174 \mathrm{~mW}\right)$, so resistor heating is negligible. Hence, the uncertainty $U_{R M}$ in $I_{R M}$ is taken to be 


$$
\begin{aligned}
U_{R M}= & \left(U_{R-D M M}\right)^{2}+\left(T_{\text {resistor }} \cdot T_{\text {coeficient-resistor }}\right)^{2}+\left(U_{\text {resistor }}\right)^{2}+\left(U_{\text {stability }}\right)^{2} \\
& =\left[(0.008)^{2}+(15 \cdot 0.0005)^{2}+(0.02)^{2}+(0.003)^{2}\right]^{0.5} \\
& =0.022 \% .
\end{aligned}
$$

The distribution is taken to be rectangular in the absence of further information.

The measured current of the cell under test $I_{T M}$ is the voltage measured across a current sense resistor with an Agilent 34401A multimeter with 1-power-line cycle integration period, as shown in Fig. 12. Depending on the current range and current limit, a particular Riedon resistor is selected to maintain between 30 and $300 \mathrm{mV}$ across the resistor. The precision 4-terminal lowtemperature coefficient Riedon resistors are nominally $0.01,0.1,1.0,10$, and 100 ohms. A typical short-circuit current for a test cell is $130 \mathrm{~mA}$. So, the software would select the $1-\mathrm{V}$ range and a 1-ohm current sense resistor. This is near the worst-case scenario, being at the low end of the meter $1-\mathrm{V}$ range. From the 1-year 34401A manufacturer's specification, the uncertainty on the $1-\mathrm{V}$ range is $0.0040 \%$ of the reading plus $0.0007 \%$ of the range plus $0.001 \%$ of range because the power-line cycle was not longer than 1 . The meter uncertainties are based on a $23 \pm 15^{\circ} \mathrm{C}$ operating temperature $\left(0.005 \% /{ }^{\circ} \mathrm{C}\right)$. The total error $U_{I-D M M}$ of the voltage reading is

$$
\begin{aligned}
& U_{I-D M M}=[\% \text { of reading }+ \text { temperature correction }]+[\% \text { of range }+ \text { temperature correction }]= \\
& 100 \cdot\{[(0.0040+15 \cdot 0.0005) \cdot 0.01 \cdot 0.130]+ \\
& {[(0.0007+15 \cdot 0.0001+0.001) \cdot 0.01 \cdot 1.0]\} / 0.130=0.021 \% }
\end{aligned}
$$

The uncertainty of the Riedon Corporation model PF1121 1-ohm resistor calibration is $0.02 \%$. The resistor temperature coefficient is negligible at $5 \mathrm{ppm} /{ }^{\circ} \mathrm{C}=0.0005 \% /{ }^{\circ} \mathrm{C}$. The 1 -year stability of the resistor is specified as $0.01 \%$ / year. For currents above $5 \mathrm{~A}$, the 1 -year stability is $0.1 \% /$ year. The power rating of the Riedon resistor is $30 \mathrm{~W}$ and the power dissipated across the resistor is $\left[1 \mathrm{ohm} \cdot(0.130 \mathrm{~A})^{2}=17 \mathrm{~mW}\right]$, so resistor heating is negligible. Hence, $U_{T M}$, the uncertainty in $I_{T M}$, is taken to be

$$
\begin{aligned}
U_{T M}= & {\left[\left(U_{I-D M M}\right)^{2}+\left(T_{\text {resistor }} \cdot T_{\text {coeficient-resistor }}\right)^{2}+\left(U_{\text {resistor }}\right)^{2}+\left(U_{\text {stability }}\right)^{2}\right]^{0.5} } \\
& =\left[(0.021)^{2}+(15 \cdot 0.0015)^{2}+(0.02)^{2}+(0.01)^{2}\right]^{0.5}=0.038 \%
\end{aligned}
$$

The distribution is taken to be rectangular. For currents $>5 \mathrm{~A}$, the $U_{T M}=0.11 \%$.

The uncertainty in the reference cell, $I_{R R}$, has been determined elsewhere and confirmed by international intercomparisons to be less than 1\% [11-21]. From the uncertainty analysis for a typical Si primary reference cell calibrated at NREL, the uncertainty in $I_{R R}$ is $0.91 \%$ with a coverage of 2 or $95 \%$ confidence.

There is an uncertainty in $I_{R M}$ and $I_{T M}$ because of temperature. The temperature is controlled with a thermoelectrically controlled plate capable of maintaining a temperature to within $0.1^{\circ} \mathrm{C}$. The important parameter is how close the measured temperature of the reference cell and test cell are to the reference temperature. The reference temperature is typically $25^{\circ} \mathrm{C}$ and the temperature is controlled to within $\pm 1^{\circ} \mathrm{C}$. Assuming a typical short-circuit temperature coefficient of $0.05 \% /{ }^{\circ} \mathrm{C}$ gives $0.05 \%$ for the temperature uncertainty of the test cell $U_{T T}$ and reference cell $U_{T R}$. 
There is an additional uncertainty in $I_{T M}, U_{S}$, because the light in the test plane is not spatially uniform. This error is a function of the size of the reference cell compared with the test cell and how close the monitor is to the cell under test. The spatial uniformity also changes with intensity fluctuations. This error source varies from set-up to set-up. But only one measurement of transfer calibration and one set-up is performed to obtain $I_{M R}$, so this error is a Type B error source with a rectangular distribution. The uncertainty in $\mathrm{U}_{\mathrm{S}}$ is estimated to be $0.5 \%$.

Type A error sources arise from the calibration of the intensity monitor $I_{M R}$ and a least-squares fit to the restricted I-V data set to obtain $\mathrm{I}_{\mathrm{TR}}$. The standard deviation $R_{T}$ for $I_{M R}$ is typically $0.02 \%$, with the number of readings averaged equal to 125. The standard deviation for $I_{T R}\left(I_{s c}\right)$ in Fig. 13 is $R_{C}=0.03 \%$ for a fit to $16 \mathrm{I}-\mathrm{V}$ points. This is the standard deviation of the intercept [25]. The uncertainty in the voltage in the linear regression is taken to be 0 because the intercept is the parameter of interest and the voltage is measured at the same time (group trigger) with the same model of meter (34401A) and has an estimated uncertainty of less than $1 \mathrm{mV}$ or $0.02 \%$. All other error sources are Type B because they do not involve averages of repeated measurements.

The uncertainty in the spectral correction factor $M$ is a function of the magnitude of $M[13,22]$. A conservative estimate of the uncertainty in $M$ is $20 \%$ of the value of $M[13,22]$. Since the restrictions on the cells make $M$ less than $2 \%$ (0.98 to 1.02), then the uncertainty in $M$ is taken to be $U_{M}=0.40 \%$. This is less than the uncertainty for the outdoor calibrations because the spectral irradiance over the entire range of the cavity radiometer is less well known. For simulator measurements, the spectral irradiance is measured over the entire response range of the PV test and reference cell. The distribution is taken to be normal (Gaussian) based on Monte Carlo perturbation analysis $[11,20]$.

The expanded uncertainty with $95 \%$ confidence (coverage $=2$ ) in the short-circuit current is

$U_{I_{s c}}=2\left[\begin{array}{l}\left(\frac{U_{T M}}{\sqrt{3}}\right)^{2}+\left(\frac{U_{M M}}{\sqrt{3}}\right)^{2}+\left(\frac{U_{M M^{\prime}}}{\sqrt{3}}\right)^{2}+\left(\frac{U_{R R}}{\sqrt{3}}\right)^{2}+\left(\frac{U_{R M}}{\sqrt{3}}\right)^{2} \\ +\left(\frac{R_{T}}{\sqrt{125}}\right)^{2}+\left(\frac{R_{C}}{\sqrt{16}}\right)^{2}+\left(\frac{U_{T T}}{\sqrt{3}}\right)^{2}+\left(\frac{U_{T R}}{\sqrt{3}}\right)^{2}+\left(\frac{U_{S}}{\sqrt{3}}\right)^{2}+\left(\frac{U_{M}}{2}\right)^{2}\end{array}\right]^{0.5}$

$U_{I_{s c}}=2\left[\begin{array}{l}\left(\frac{0.038}{\sqrt{3}}\right)^{2}+\left(\frac{0.025}{\sqrt{3}}\right)^{2}+\left(\frac{0.025}{\sqrt{3}}\right)^{2}+\left(\frac{0.91}{\sqrt{3}}\right)^{2}+\left(\frac{0.027}{\sqrt{3}}\right)^{2} \\ +\left(\frac{0.02}{\sqrt{125}}\right)^{2}+\left(\frac{0.03}{\sqrt{16}}\right)^{2}+\left(\frac{0.05}{\sqrt{3}}\right)^{2}+\left(\frac{0.05}{\sqrt{3}}\right)^{2}+\left(\frac{0.5}{\sqrt{3}}\right)^{2}+\left(\frac{0.4}{2}\right)^{2}\end{array}\right]^{0.5}$

$U_{I_{s c}}=1.27 \%$.

For currents above $5 \mathrm{~A}, U_{\text {Isc }}=1.36 \%$. 


\subsection{Uncertainty in $\boldsymbol{P}_{\max }$}

The maximum power, $P_{\max }$, is defined as the maximum of the product of the current and voltage under standard reporting conditions. The maximum power is a function of contacting because of the distributed resistance nature of photovoltaics. The uncertainty from this error source is zero because the analysis assumes that separate voltage and current wires are attached to the cell. The current at $P_{\max }$ is defined as $I_{\max }$, while the voltage at $P_{\max }$ is $V_{\max }$. The largest measured power may not be the maximum power because of noise on the measured current versus voltage. For this reason, the maximum power is obtained by a polynomial curve fit to a restricted set of data points. The fitting constraints on the restricted $\left(V, I_{T R}\right)$ data are based on the largest measured power $P_{m}$ and the voltage $V_{m}$ at $P_{m}$.

$$
0.85 \cdot P_{m} \leq P \leq 1.15 \cdot P_{m}
$$

and

$0.8 \cdot V_{m} \leq V \leq 1.2 \cdot V_{m}$,

where $P$ is the product of the measured voltage and corrected current $I_{T R}$. This procedure reduces the uncertainty in the "true" maximum power by allowing least-squares polynomial curve-fitting to "average" over multiple data points. The uncertainty $U_{P-\text { fit }}$ in the fit of the restricted current versus voltage data $U_{P \max }$ was determined to be less than $0.06 \%$ by modeling the $I-V$ data of the test case using the standard diode equation with series and shunt resistance and a similar number of points in the fit and introducing a random error in the current until the mean square error of the fit was within $1 \%$ of the actual measured data and modeled data. The temperature coefficient of the voltage was assumed to be $0.5 \% /{ }^{\circ} \mathrm{C}$ giving $U_{T V}$. Since the data are not corrected for temperature, the error in the power is a function of the deviation from the reference temperature. In this analysis, the deviation of "true" cell temperature from the reference temperature is assumed to be $\pm 1^{\circ} \mathrm{C}$. The error in the voltage meter $U_{V-D M M}$ is based on a single voltage reading at 10-line-cycles integration period and a voltage of $0.4488 \mathrm{~V}$ (from Fig. 12).

$$
\begin{aligned}
& U_{V-D M M}=[\% \text { of reading }+ \text { temperature correction }]+[\% \text { of range }+ \text { temperature correction }]= \\
& \quad 100 \cdot\{[(0.0007+15 \cdot 0.0005) \cdot 0.01 \cdot 0.449]+ \\
& \quad[(0.0040+15 \cdot 0.0001) \cdot 0.01 \cdot 1]\} / 0.449=0.0095
\end{aligned}
$$

The expanded uncertainty with $95 \%$ confidence (coverage $=2$ ) in the maximum power is

$$
\begin{aligned}
& U_{P_{\max }}=2\left[\begin{array}{l}
\left(\frac{U_{T M}}{\sqrt{3}}\right)^{2}+\left(\frac{U_{M M}}{\sqrt{3}}\right)^{2}+\left(\frac{U_{M M^{\prime}}}{\sqrt{3}}\right)^{2}+\left(\frac{U_{R R}}{\sqrt{3}}\right)^{2}+\left(\frac{U_{R M}}{\sqrt{3}}\right)^{2}+\left(\frac{R_{T}}{\sqrt{125}}\right)^{2} \\
+\left(\frac{U_{T T}}{\sqrt{3}}\right)^{2}+\left(\frac{U_{T R}}{\sqrt{3}}\right)^{2}+\left(\frac{U_{S}}{\sqrt{3}}\right)^{2}+\left(\frac{U_{M}}{2}\right)^{2}+\left(\frac{U_{P-f i t}}{2}\right)^{2}+\left(\frac{U_{T V}}{\sqrt{3}}\right)^{2}+\left(\frac{U_{V}}{\sqrt{3}}\right)^{2}
\end{array}\right]^{0.5} \\
& U_{P_{\max }}=2\left[\begin{array}{l}
\left(\frac{0.038}{\sqrt{3}}\right)^{2}+\left(\frac{0.025}{\sqrt{3}}\right)^{2}+\left(\frac{0.025}{\sqrt{3}}\right)^{2}+\left(\frac{0.91}{\sqrt{3}}\right)^{2}+\left(\frac{0.027}{\sqrt{3}}\right)^{2}+\left(\frac{0.02}{\sqrt{125}}\right)^{2} \\
+\left(\frac{0.05}{\sqrt{3}}\right)^{2}+\left(\frac{0.05}{\sqrt{3}}\right)^{2}+\left(\frac{0.5}{\sqrt{3}}\right)^{2}+\left(\frac{0.4}{2}\right)^{2}+\left(\frac{0.06}{2}\right)^{2}+\left(\frac{0.5}{\sqrt{3}}\right)^{2}+\left(\frac{0.009}{2}\right)^{2}
\end{array}\right] \\
& U_{P_{\max }}=1.40 \% .
\end{aligned}
$$


The uncertainty in $V_{\max }$ and $I_{\max }$ can be conservatively estimated to be less than the uncertainty in $P_{\max }$ and greater than the uncertainty in $I_{s c}$. A more accurate estimate is difficult because of the sample-specific nonanalytic nonlinear relationship between the uncertainty $P_{\max }, I_{\max }$, and $V_{\max }$. The uncertainty in $V_{\max }$ is greater than the uncertainty in $V_{o c}$ because of additional resistancerelated error sources. Hence,

$$
U_{I_{\max }}=1.4 \%
$$

and

$$
U_{V_{\max }}=0.7 \% \text {. }
$$

\subsection{Uncertainty in $\mathrm{V}_{\text {oc }}$}

The open-circuit voltage is measured with the cell open-circuited with a single 10-line-cycle integration period reading $\left(0.580 \mathrm{~V}\right.$ from Fig. 12). The dominant error is from $\mathrm{a} \pm 1^{\circ} \mathrm{C}$ uncertainty in temperature, resulting in an uncertainty in the voltage $U_{T V}$. The $V_{o c}$ error from an error in the irradiance is assumed to be zero because the irradiance is constrained to be within $\pm 2 \%$ of standard reference conditions by procedures. This error is a function of the cell and is logarithmic in nature.

$$
\begin{aligned}
U_{V}= & {[\% \text { of reading }+ \text { temperature correction }]+[\% \text { of range }+ \text { temperature correction }]=} \\
& 100 \cdot\{[(0.004+15 \cdot 0.0005) \cdot 0.01 \cdot 0.580]+ \\
& {[(0.0035+15 \cdot 0.0005) \cdot 0.01 \cdot 1]\} / 0.580=0.006 \% . }
\end{aligned}
$$

$U_{V_{o c}}=2\left[\left(\frac{U_{T V}}{\sqrt{3}}\right)^{2}+\left(\frac{U_{V}}{2}\right)^{2}\right]^{0.5}$

$U_{V_{o c}}=2\left[\left(\frac{0.5}{\sqrt{3}}\right)^{2}+\left(\frac{0.006}{\sqrt{3}}\right)^{2}\right]^{0.5}$

$U_{V_{o c}}=0.58$.

\subsection{Uncertainty in Area}

Two components of the uncertainty in the area are related to the subjective interpretation of the edge of the cell and the ability to measure the distance between edges. We consider the typical reference cell nominal dimensions area of $2 \mathrm{~cm}$ by $2 \mathrm{~cm}$. The $x-y$ coordinates of the four corners are recorded, and the area is calculated from the following formula for a general quadrilateral:

$$
\begin{gathered}
A=\text { absolute value }\left\{\left[\left(\mathrm{x}_{4}-\mathrm{x}_{1}\right)\left(\mathrm{y}_{1}-\mathrm{y}_{2}\right)-\left(\mathrm{x}_{1}-\mathrm{x}_{2}\right)\left(\mathrm{y}_{4}-\mathrm{y}_{1}\right)\right]+\left[\left(\mathrm{x}_{1}-\mathrm{x}_{2}\right)\left(\mathrm{y}_{2}-\mathrm{y}_{3}\right)-\left(\mathrm{x}_{2}-\mathrm{x}_{3}\right)\left(\mathrm{y}_{1}-\mathrm{y}_{2}\right)\right]+\right. \\
\left.\left[\left(\mathrm{x}_{2}-\mathrm{x}_{3}\right)\left(\mathrm{y}_{3}-\mathrm{y}_{4}\right)-\left(\mathrm{x}_{3}-\mathrm{x}_{4}\right)\left(\mathrm{y}_{2}-\mathrm{y}_{3}\right)\right]+\left[\left(\mathrm{x}_{3}-\mathrm{x}_{4}\right)\left(\mathrm{y}_{4}-\mathrm{y}_{1}\right)-\left(\mathrm{x}_{4}-\mathrm{x}_{1}\right)\left(\mathrm{y}_{3}-\mathrm{y}_{4}\right)\right]\right\} / 4 .
\end{gathered}
$$

However, if the sides are all the same length and at right angles and are aligned with the x-axis, then 
$\mathrm{x}_{4}-\mathrm{x}_{1}=\mathrm{x}_{2}-\mathrm{x}_{3}=0$

$x=\mathrm{x}_{1}-\mathrm{x}_{2}=\mathrm{x}_{3}-\mathrm{x}_{4}$

$\mathrm{y}_{3}-\mathrm{y}_{4}=\mathrm{y}_{1}-\mathrm{y}_{2}=0$

$y=y_{4}-y_{1}=y_{2}-y_{3}$.

Hence, the uncertainty in the area can be determined from the average of eight distance measurements. The values are measured with a resolution of $2-\mu \mathrm{m}$ uncertainty in the distance. The microscope can resolve features below $1 \mu \mathrm{m}$ in size. For a typical $2-\mathrm{cm}$ by 2 -cm cell under glass, using the microscope with optimum magnification, it is estimated that the subjective edge resolution is $20 \mu \mathrm{m}$. Hence, the uncertainty in the distance measurement is $100 \cdot 0.0022 / 2=$ $0.11 \%$. In the absence of further information, we use a rectangular distribution in the uncertainty in measuring the four corner $x-y$ coordinates (eight distance measurements). Intercomparison among trained operators in the testing group indicates that a subjective error arising from the operator's judgment of where the sample edge is located introduces a $0.7 \%$ random error.

$U_{A}=2\left[\left(\frac{0.7}{\sqrt{3}}\right)^{2}+\left(\frac{8 \cdot 0.11}{2}\right)^{2}\right]^{0.5}=1.20 \%$.

The assumption of a square aligned with the stage's $\mathrm{x}$-axis in determining the uncertainty is justified because there is no loss in uncertainty if the sample is misaligned with respect to the stage or if the sides are not equal length.

\subsection{Uncertainty in Efficiency}

The efficiency with respect to standard reference conditions defined by a temperature, spectral, and total irradiance can be written as

$$
\eta=100 \frac{P_{\max }}{E_{r e f} A}
$$

The uncertainty in $\eta$ can be written as

$$
U_{\eta}=2\left[\left(\frac{U_{A}}{\sqrt{3}}\right)^{2}+\left(\frac{U_{P_{\max }}}{\sqrt{3}}\right)^{2}\right]^{0.5}=2\left[\left(\frac{1.20}{2}\right)^{2}+\left(\frac{1.40}{2}\right)^{2}\right]^{0.5}=1.84 \%
$$

\subsection{Uncertainty in Fill Factor}

The fill factor, $F F$, is defined as

$$
F F \equiv 100 \frac{P_{\max }}{V_{o c} I_{s c}}
$$


The uncertainty $U_{F F}$ in FF can be written as

$$
U_{F F}=2\left[\left(\frac{U_{P_{\max }}}{\sqrt{3}}\right)^{2}+\left(\frac{U_{V_{o c}}}{\sqrt{3}}\right)^{2}+\left(\frac{U_{I_{s c}}}{\sqrt{3}}\right)^{2}\right]^{0.5}=2\left[\left(\frac{1.40}{\sqrt{3}}\right)^{2}+\left(\frac{0.58}{\sqrt{3}}\right)^{2}+\left(\frac{1.27}{\sqrt{3}}\right)^{2}\right]^{0.5}=1.98 \%,
$$

assuming that $V_{o c}, I_{s c}$, and $P_{\max }$ are not correlated. In fact, to a first order, increasing $I_{s c}$ by a given percentage will increase $P_{\max }$ by the same percentage. Furthermore, the constraints on the measurement require that the fill factor be measured within $2 \%$ of the correct irradiance. For devices that are not series resistance-limited, a $2 \%$ variation in intensity will have a negligible effect on the fill factor. A more realistic estimate of the uncertainty in FF would be to remove all terms related to the uncertainty in the irradiance. This leaves errors related to temperature, current measurement meter, voltage measurement meter, and curve fits.

$$
\begin{aligned}
& U_{F F}=2\left[\left(\frac{U_{T V}}{\sqrt{3}}\right)^{2}+\left(\frac{U_{V}}{\sqrt{3}}\right)^{2}+\left(\frac{U_{R-D M M}}{\sqrt{3}}\right)^{2}+\left(\frac{U_{I-D M M}}{\sqrt{3}}\right)^{2}+\left(\frac{U_{M-D M M}}{\sqrt{3}}\right)^{2}+\left(\frac{U_{T T}}{\sqrt{3}}\right)^{2}+\left(\frac{R_{C}}{\sqrt{15}}\right)^{2}+\left(\frac{U_{P-f i t}}{2}\right)^{2}\right]^{0.5} \\
& U_{F F}=2\left[\left(\frac{0.5}{\sqrt{3}}\right)^{2}+\left(\frac{0.006}{\sqrt{3}}\right)^{2}+\left(\frac{0.016}{\sqrt{3}}\right)^{2}+\left(\frac{0.021}{\sqrt{3}}\right)^{2}+\left(\frac{0.013}{\sqrt{3}}\right)^{2}+\left(\frac{0.05}{\sqrt{3}}\right)^{2}+\left(\frac{0.03}{\sqrt{15}}\right)^{2}+\left(\frac{0.06}{2}\right)^{2}\right]^{0.5} \\
& U_{F \mathrm{~F}}=0.58 .
\end{aligned}
$$

\section{References for Section 4}

1. ASTM Standard E948, Standard Test Methods for Electrical Performance of NonConcentrator Photovoltaic Cells Using Reference Cells, Amer. Society for Testing Matls., West Conshocken PA, USA.

2. ASTM Standard 1036, Specification for Physical Characteristics of Non-Concentrator Photovoltaic Reference Cells, Amer. Society for Testing Matls., West Conshocken PA, USA.

3. ASTM Standard G159, Standard Tables for Reference Solar Spectral Irradiances: Direct Normal and Hemispherical on $37^{\circ}$ Tilted Surfaces, Amer. Society for Testing Matls., West Conshocken PA, USA.

4. ASTM Standard G173, Standard Tables for Reference Solar Spectral Irradiances: Direct Normal and Hemispherical on $37^{\circ}$ Tilted Surfaces, Amer. Society for Testing Matls., West Conshocken PA, USA.

5. ASTM Standard E1328, Standard Terminology Relating to Photovoltaic Solar Energy Conversions, Amer. Society for Testing Matls., West Conshocken PA, USA.

6. ASTM Standard E1021, Standard Test Methods for Measuring Spectral Response of Photovoltaic Cells, Amer. Society for Testing Matls., West Conshocken PA, USA.

7. ASTM Standard E973, Standard Test Method for Determination of the Spectral Mismatch Parameter Between a Photovoltaic Device and a Photovoltaic Reference Cells, Amer. Society for Testing Matls., West Conshocken PA, USA.

8. ASTM Standard E1021, Standard Test Methods for Measuring Spectral Response of Photovoltaic Cells, Amer. Society for Testing Matls., West Conshocken PA, USA. 
9. K.A. Emery, C.R. Osterwald, T.W. Cannon, D.R. Myers, J. Burdick, T. Glatfelter, W. Czubatyj, and J. Yang, "Methods for Measuring Solar Cell Efficiency Independent of Reference Cell or Light Source," Proc. 18 ${ }^{\text {th }}$ IEEE Photovoltaic Spec. Conf., Las Vegas, NV, October 21-25, 1985, pp.623-628, IEEE, New York, 1985.

10. C.R. Osterwald, (1986), Translation of Device Performance Measurements to Reference Conditions, Solar Cells, 18, pp.269-279.

11. C.R. Osterwald, K.A. Emery, D.R. Myers, and C.J. Riordan, "Extending the Spectral Range of Silicon-Based Direct-Beam Solar Spectral Radiometric Measurements," Proc. $20^{\text {th }}$ IEEE Photovoltaic Specialists Conf., Las Vegas, NV, September 26-30, 1988, pp.1246-1250, IEEE, New York, 1989.

12. C.R. Osterwald, K.A. Emery, D.R. Myers, and R.E. Hart, "Primary Reference Cell Calibrations at SERI: History and Methods," Proc. $21^{\text {st }}$ IEEE Photovoltaic Specialists Conf., Orlando, FL, May 21-25, 1990, pp.1062-1067, IEEE, New York, 1990.

13. K. A. Emery, C.R. Osterwald, S. Rummel, D.R. Myers, T.L. Stoffel, and D. Waddington, "A Comparison of Photovoltaic Calibration Methods," Proc. $9^{\text {th }}$ European Photovoltaic Solar Energy Conf., Freiburg, W. Germany, September 25-29, 1989, pp.648-651.

14. K.A. Emery, C.R. Osterwald, and C.V. Wells, "Uncertainty Analysis of Photovoltaic Efficiency Measurements," Proc. $19^{\text {th }}$ IEEE Photovoltaic Specialists Conf., New Orleans, LA, May 4-8, pp.153-159, IEEE, New York, 1987.

15. H. Ossenbrink, R. Van Steenwinkel, and K. Krebs, "The Results of the 1984/1985 RoundRobin Calibration of Reference Solar Cells for the Summit Working Group on Technology, Growth and Employment," Joint Research Center, ISPRA Establishment, ISPRA Italy, Tech Rep. EUR 10613 EN (April 1986).

16. K.A. Emery, C.R. Osterwald, L.L. Kazmerski, and R.E. Hart, "Calibration of Primary Terrestrial References Cells When Compared with Primary AM0 Reference Cells," Proc. $8^{\text {th }}$ European Photovoltaic Solar Energy Conf., Florence, Italy, May 9-12, 1988, pp.64-68.

17. K.A. Emery, D. Waddington, S. Rummel, D.R. Myers, T.L. Stoffel, and C.R. Osterwald, "SERI Results from the PEP 1987 Summit Round Robin and a Comparison of Photovoltaic Calibration Methods," SERI Tech. Rep. TR-213-3472, March 1989.

18. J. Metzdorf, T. Wittchen, K. Heidler, K. Dehne, R. Shimokawa, F. Nagamine, H. Ossenbrink, L. Fornarini, C. Goodbody, M. Davies, K. Emery, and R. Deblasio, "Objectives and Results of the PEP '87 Round-Robin Calibration of Reference Cells and Modules," Proc. $21^{\text {st }}$ IEEE Photovoltaic Specialists Conf., Orlando, FL, May 21-25, 1990, pp.952-959, IEEE, New York, 1990.

19. J. Metzdorf, T. Wittchen, K. Heidler, K. Dehne, R. Shimokawa, F. Nagamine, H. Ossenbrink, L. Fornarini, C. Goodbody, M. Davies, K. Emery, and R. Deblasio, "The Results of the PEP '87 Round-Robin Calibration of Reference Cells and Modules,- Final Report” PTB Technical Report PTB-Opt-31, Braunschweig, Germany, November 1990, ISBN 3-89429-067-6.

20. C.R. Osterwald, S. Anevsky, A.K. Barua, J. Dubard, K. Emery, D. King, J. Metzdorf, F. Nagamine, R. Shimokawa, N. Udayakumar, Y.X. Wang, W. Zaaiman, A. Zastrow, and J. Zhang, "Results of the PEP '93 Intercomparison of Reference Cell Calibrations and Newer Technology Performance Measurements," Proc. 25 $5^{\text {th }}$ IEEE Photovoltaic Specialists Conf., Washington D.C., May 13-17, 1996, pp.1263-1266, IEEE, New York, 1996.

21. C.R. Osterwald, S. Anevsky, A.K. Barua, J. Dubard, K. Emery, D. King, J. Metzdorf, F. Nagamine, R. Shimokawa, N. Udayakumar, Y.X. Wang, T. Wittchen, W. Zaaiman, A. Zastrow, and J. Zhang, "Results of the PEP'93 Intercomparison of Reference Cell Calibrations and Newer Technology Performance Measurements," Proc. $26^{\text {th }}$ IEEE PVSC Conf., Anaheim, CA. Sept. 29-Oct. 2, 1997, pp.1209-1212, IEEE, New York, 1997. 
22. Keith Emery, "The Results of the First World Photovoltaic Scale Recalibration," NREL Tech. Rep. NREL/TP-520-27942, (March 2000).

23. H. Field and K. Emery, "An Uncertainty Analysis of the Spectral Correction Factor," Proc. $23^{\text {rd }}$ IEEE Photovoltaic Specialists Conf., Louisville, KY, May 10-14, 1993, pp.11801187, IEEE, New York, 1993.

24. "The Expression of Uncertainty and Confidence in Measurement," United Kingdom Accreditation Service, M3003, Middlesex, UK, December 1997.

25. International Organization for Standardization, Guide to the Expression of Uncertainty in Measurement. ISO: Geneva, 1995, ISBN 92-67-10188-9.

26. M.G. Natrella, "Experimental Statistics," National Bureau of Standards Handbook 91, p.534. August 1, 1993, reprinted October 1966. 


\subsection{UNCERTAINTY OF ELECTRICAL PERFORMANCE OF PHOTOVOLTAIC MODULES}

\section{Reference to Norms and Standards}

- ASTM E1036 "Standard Test Methods for Electrical Performance of Nonconcentrator Terrestrial Photovoltaic Modules and Arrays Using Reference Cells. "This procedure meets or exceeds the requirements in IEC standard 60904-1, "Photovoltaic Devices Measurement of Photovoltaic Current-Voltage Characteristics."

- Procedure ISO GUM "International Organization for Standardization, Guide to the Expression of Uncertainty in Measurement. ISO: Geneva, 1995, ISBN 92-67-10188-9.

- ISO-VIM "International Vocabulary of Basic and General Terms in Metrology," $2^{\text {nd }}$ Edition 1993.

- 1.4.ASTM standard E 1328 Terminology Relating to Photovoltaic Solar Energy Conversion"

\section{Summary}

This uncertainty analysis is for ASTM E1036, "Standard Test Methods for Electrical Performance of Nonconcentrator Terrestrial Photovoltaic Modules and Arrays Using Reference Cells" [1]. The analysis is restricted to stable, single-junction modules or cells that are packaged with connectors [2]. This analysis is restricted to samples less than $150 \mathrm{~cm}$ by $120 \mathrm{~cm}$ in area. The analysis is also restricted to samples with $\mathrm{V}_{\mathrm{oc}}$ in the range of 0.5 to $290 \mathrm{~V}$ and $\mathrm{I}_{\mathrm{sc}}$ in the range of 0.1 to $50 \mathrm{~A}$. The current vs. voltage characteristics are measured within $2^{\circ} \mathrm{C}$ of the reference temperature (typically $25^{\circ} \mathrm{C}$ ) and within $2 \%$ of the reference irradiance (typically ASTM G173 global or equivalently IEC $60904-3[3,4], 1000 \mathrm{~W} / \mathrm{m}^{2}$ ). Our group has essentially been following these procedures on this test bed since its inception in 1985 [5-7]. To simplify matters, the uncertainties of the input quantities are expressed in terms of percentage of value. Since all equations are or will be reduced to multiplications and divisions, the sensitivity coefficient reduces to unity. The uncertainty of the performance parameters will then be the same for similar devices.

\section{Procedures}

The procedure from E1036 follows:

1. Measure the module or cell in module package aperture area, A, using the definition in Terminology E 1328 [8]. This is the total area minus the frame area. This may give unrealistically small current densities or low efficiencies for packages that have inactive large borders around the active cell(s).

2. Measure the relative spectral responsivity of the PV device to be calibrated using Test Method E1021 [9]. In many cases, the uncertainty and difficulties in measuring a module spectral responsivity may be prohibitive. For these cases, a cell representative of the typical responsivity of the module is acceptable.

3. Choose a primary reference cell. 
4. Determine the spectral-mismatch parameter, $M$, using Test Method E 973 [10]:

$$
M=\frac{\int_{\lambda_{1}}^{\lambda_{2}} E_{s}(\lambda) S_{t}(\lambda) \mathrm{d} \lambda \int_{\lambda_{3}}^{\lambda_{4}} E_{r e f}(\lambda) S_{r}(\lambda) \mathrm{d} \lambda}{\int_{\lambda_{3}}^{\lambda_{4}} E_{s}(\lambda) S_{r}(\lambda) \mathrm{d} \lambda \int_{\lambda_{1}}^{\lambda_{2}} E_{r e f}(\lambda) S_{t}(\lambda) \mathrm{d} \lambda},
$$

where:

$S_{t}(\lambda) \quad$ Measured spectral responsivity of the test device (Test Method E1021 [9])

$S_{r}(\lambda) \quad$ Measured spectral responsivity of the reference cell (Test Method

E1021 [9])

$E_{\text {ref }}(\lambda) \quad$ Reference spectral irradiance

$E_{S}(\lambda) \quad$ Measured spectral irradiance of the light source (Test method E973 [10])

$\lambda_{1}, \lambda_{2}, \lambda_{3}, \lambda_{4} \quad$ Wavelength limits of integration.

5. The following procedures follow E1036 for module I-V measurements [1]. These procedures are equivalent to IEC standard 60904-1.

5.1. Mount the reference cell in the center of the test plane and verify that the plate temperature or reference cell temperature are within $\pm 2^{\circ} \mathrm{C}$ of the temperature corresponding to the reference cell short-circuit current calibration value, $I_{R R}$.

5.2. Adjust the simulator so that the measured reference cell short-circuit current $I_{R M}$ is within $2 \%$ of the spectrally corrected calibration value or

$$
0.98 \leq\left(I_{R R} / M\right) / I_{R M} \leq 1.02 .
$$

5.3. Transfer this value to an intensity monitor giving a calibration value for the intensity monitor by recording the average of at least ten measurements of the following equation:

$$
I_{M R}=\left(I_{M M} I_{R R}\right) /\left(M I_{R M}\right),
$$

where:

$I_{M R}$ Calibrated short-circuit current of the intensity monitor located near the edge of the test plane

$I_{M M}$ Measured short-circuit current of the intensity monitor located near the edge of the test plane.

5.4. Mount the device to be tested on the temperature-controlled plate in the same position as the reference cell. Keep the module within $5^{\circ}$ of the reference temperature.

5.5. Measure the open-circuit voltage, $V_{o c}$, with the load disconnected. 
5.6. Measure the current versus voltage $\left(I_{T M}, V\right.$ characteristic of the device under test by changing the operating point with the variable load so that the curve is swept through $0 \mathrm{~V}$ and $0 \mathrm{~A}$. At each operating point on the $\left(\mathrm{I}_{\mathrm{TM}}, \mathrm{V}\right)$ characteristic, measure the device voltage, $V$, device current, $I_{T M}$, and $I_{M M}$. Correct the measured current, $I_{T M}$, for intensity fluctuations giving the calibrated current of the test device under the reference spectrum at the reference irradiance and temperature $I_{T R}$ using

$$
I_{T R}=I_{T M} I_{M R} / I_{M M}
$$

5.7. Measure the open-circuit voltage, $V_{o c}$, with the load disconnected.

5.8. Determine the calibrated $I_{S c}$ by performing a linear-regression fit to all $I_{T R} V$ points that satisfy the constraint that all currents are within $4 \%$ of the current at $0 \mathrm{~V}$ and all voltages are within 0.20 times the voltage at $0 \mathrm{~A}$.

5.9. Determine the maximum power, $\mathrm{P}_{\max }$, by performing a polynomial fit on all $\mathrm{I}_{\mathrm{TR}}-$ $\mathrm{V}$ points that satisfy the constraints that the measured power is within $85 \%$ of the largest measured power and the voltage is within $80 \%$ of the voltage at the largest measured power as recommended by E1036. The polynomial that gives the best fit to the data up to a fifth order is used. The voltage at maximum power, $V_{m}$ is the real root of the derivative of the fit of the power versus voltage polynomial set equal to 0 . This voltage is then substituted into the power versus voltage polynomial to obtain the $P_{\max }$. The current at maximum power, $I_{\max }$, is calculated from the $P_{\text {max }} / V_{\text {max }}$.

5.10. The current vs. voltage data points, $\left(I_{T R}, V\right)$, along with a variety of information including $V_{o c}, I_{s c}, P_{\max }$, temperature, time, device ID, device type, manufacturer, reference cell, and its calibration, the record book number and page, and change in $V_{o c}$ before and after the measurement, are saved. 


\section{Test-Bed-Specific Equipment}

Figure 14 is a photograph of the test bed, and Figure 15 shows a simplified block diagram of the test bed.

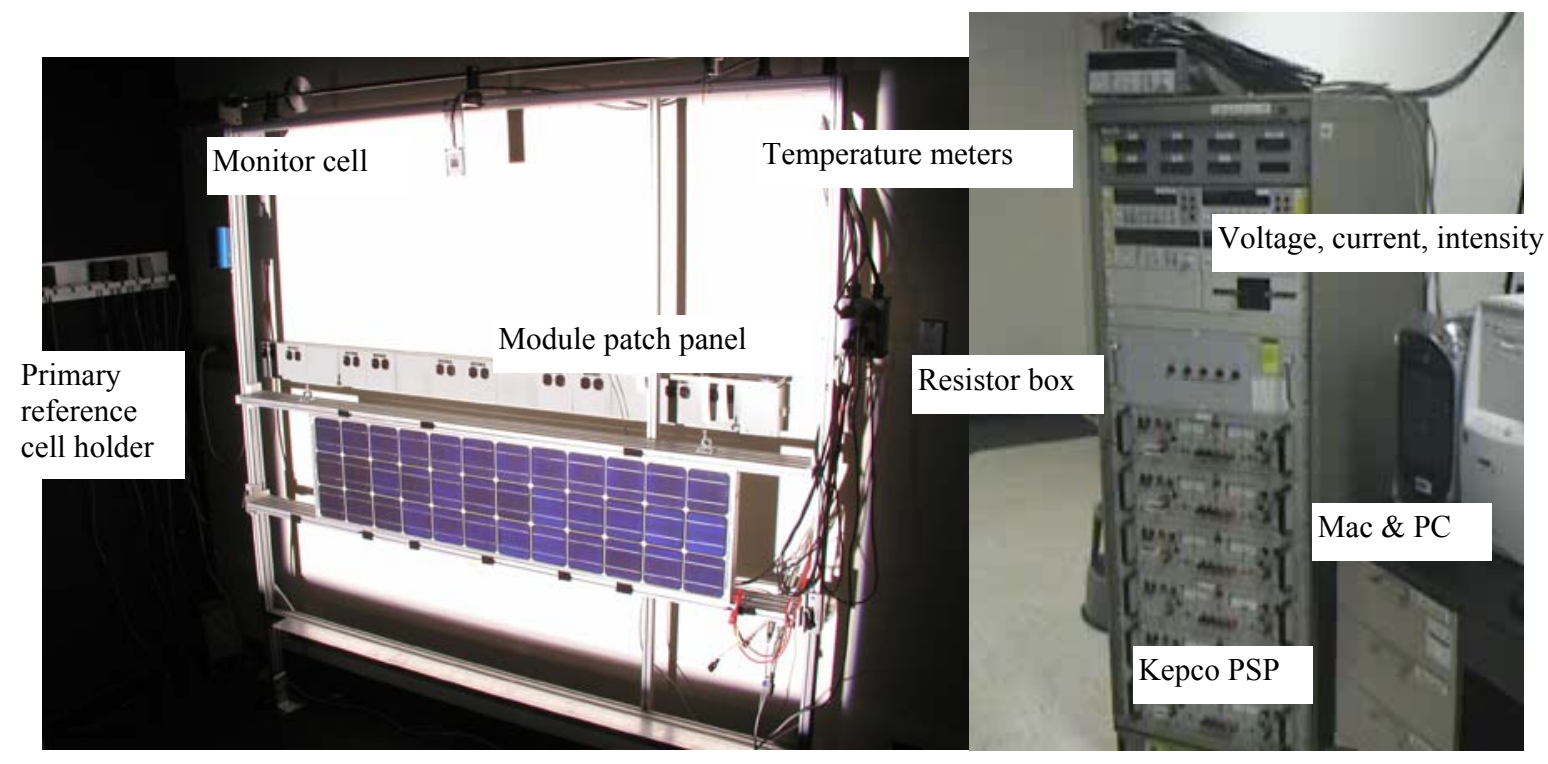

Figure 14. The Spectrolab LACSS solar simulator and custom I-V measurement system.

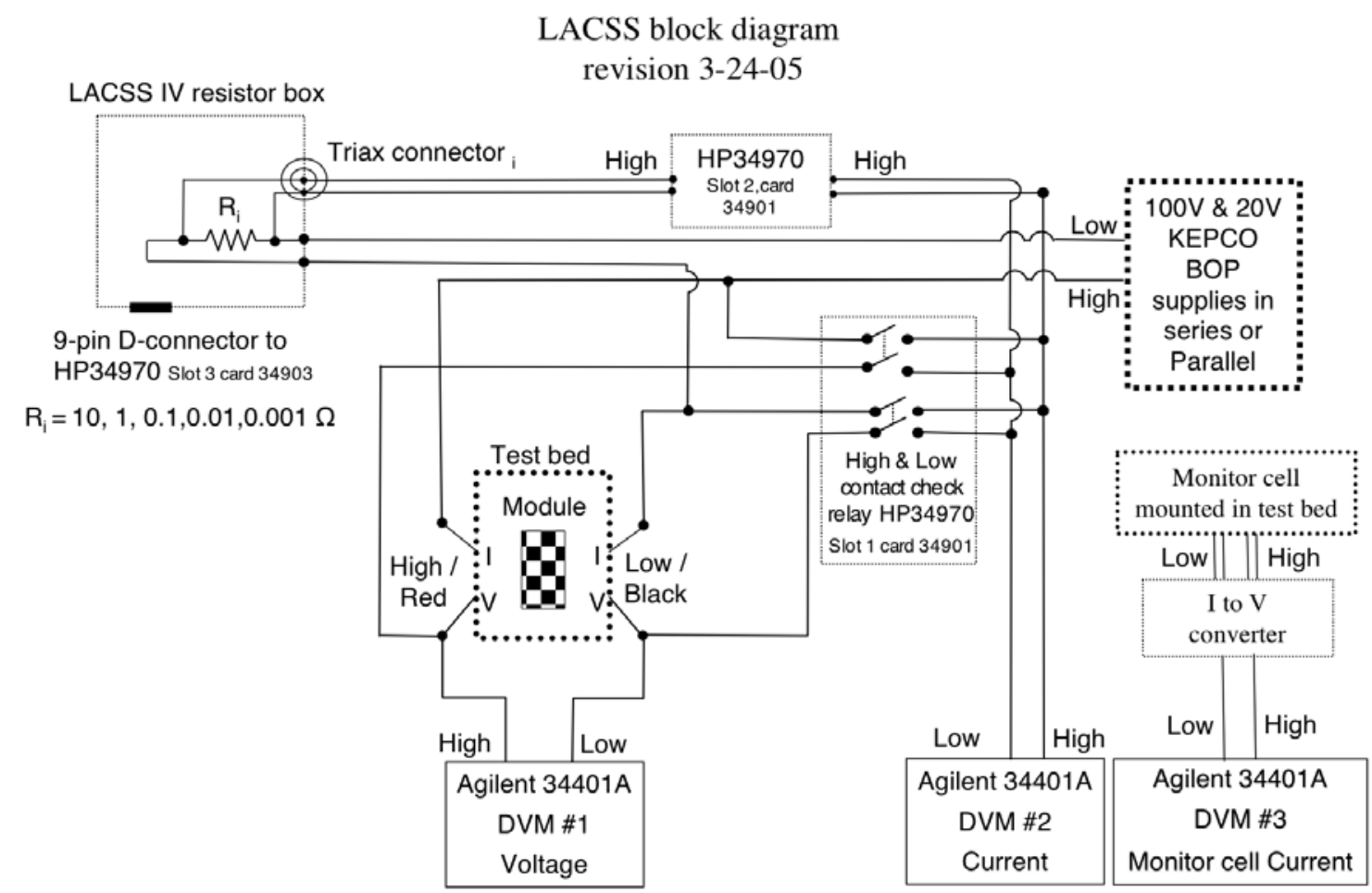

Figure 15. Simplified block diagram of current versus voltage test station. 


\section{Uncertainty Analysis}

Table 8 summarizes the standard uncertainty components. All uncertainty components are given in percentage with a $55-\mathrm{cm}$ by $32-\mathrm{cm} \mathrm{Si} \mathrm{module} \mathrm{as} \mathrm{the} \mathrm{reference} \mathrm{case.} \mathrm{All} \mathrm{uncertainties} \mathrm{are} \mathrm{based}$ on a 1-year calibration interval.

Table 8. Summary of Standard Secondary Reference Module Uncertainty Components

\begin{tabular}{|c|c|c|c|}
\hline $\begin{array}{l}\text { Uncertainty } \\
\text { Component }\end{array}$ & Source of Uncertainty & $\begin{array}{c}\text { Value of } \\
\text { Uncertainty } \\
(\%)\end{array}$ & $\begin{array}{l}\text { Coverage } \\
\text { Factor }\end{array}$ \\
\hline \multirow[t]{5}{*}{$\mathrm{U}_{\mathrm{M}-\mathrm{DMM}}$} & Intensity Monitor meter (94 mV typical value) & 0.018 & Rectangular \\
\hline & 1-year HP34401, $100 \mathrm{mV}$, of reading & 0.005 & Rectangular \\
\hline & 1-year HP34401, $100 \mathrm{mV}$, of range & 0.0035 & Rectangular \\
\hline & 1-year HP34401, $100 \mathrm{mV}, 1$ line cycle & 0.001 & Rectangular \\
\hline & $\mathrm{HP} 34401,100 \mathrm{mV}$, meter temperature $23 \pm 15^{\circ} \mathrm{C}$ & 0.0075 & Rectangular \\
\hline \multirow[t]{4}{*}{$\mathrm{U}_{\mathrm{MM}}, \mathrm{U}_{\mathrm{MM}}$} & Measured Monitor current & 0.029 & Rectangular \\
\hline & 1-year resistor stability (Julie CH-48T4 data sheet) & 0.003 & Rectangular \\
\hline & 1-year resistor calibration uncertainty & 0.02 & Rectangular \\
\hline & Resistor temperature $0.0005 \% /{ }^{\circ} \mathrm{C}$ & 0.0075 & Rectangular \\
\hline \multirow[t]{4}{*}{$\mathrm{U}_{\mathrm{R}-\mathrm{DMM}}$} & Reference cell DMM (101 mA typical value) & 0.017 & Rectangular \\
\hline & 1-year HP34401, $100 \mathrm{mV}$, of reading & 0.005 & Rectangular \\
\hline & 1-year HP34401, $100 \mathrm{mV}$, of range & 0.0035 & Rectangular \\
\hline & $\mathrm{HP} 34401,100 \mathrm{mV}$, meter temperature $23 \pm 15^{\circ} \mathrm{C}$ & 0.0075 & Rectangular \\
\hline \multirow[t]{4}{*}{$\mathrm{U}_{\mathrm{RM}}$} & Measured reference cell current & 0.028 & Rectangular \\
\hline & 1-year resistor stability (Julie CH-48T4 data sheet) & 0.003 & Rectangular \\
\hline & 1-year calibration uncertainty & 0.02 & Rectangular \\
\hline & Resistor temperature $0.0015 \% /{ }^{\circ} \mathrm{C}$ & 0.0225 & Rectangular \\
\hline \multirow[t]{5}{*}{$\mathrm{U}_{\mathrm{I}-\mathrm{DMM}}$} & Test device current DMM (1.41 A typical value) & 0.055 & Rectangular \\
\hline & 1-year HP34401, $100 \mathrm{mV}$, of reading & 0.005 & Rectangular \\
\hline & 1-year HP34401, $100 \mathrm{mV}$, of range & 0.0035 & Rectangular \\
\hline & 1-year HP34401, $100 \mathrm{mV}, 1$ line cycle & 0.001 & Rectangular \\
\hline & $\mathrm{HP} 34401,100 \mathrm{mV}$, meter temperature $23 \pm 15^{\circ} \mathrm{C}$ & 0.0075 & Rectangular \\
\hline \multirow[t]{4}{*}{$\mathrm{U}_{\mathrm{TM}}$} & Measured test device current & 0.120 & Rectangular \\
\hline & 1-year resistor stability & 0.1 & Rectangular \\
\hline & 1-year resistor calibration uncertainty & 0.02 & Rectangular \\
\hline & Resistor temperature $0.002 \% /{ }^{\circ} \mathrm{C}$ & 0.03 & Rectangular \\
\hline $\mathrm{U}_{\mathrm{TT}}$ & Test device current for $\pm 2^{\circ} \mathrm{C}$ & 0.10 & Rectangular \\
\hline $\mathrm{U}_{\mathrm{TR}}$ & Reference cell current for $\pm 5^{\circ} \mathrm{C}$ & 0.25 & Rectangular \\
\hline $\mathrm{U}_{\mathrm{RR}}$ & Primary reference cell calibration value & 0.91 & Rectangular \\
\hline $\mathrm{R}_{\mathrm{C}}$ & $\begin{array}{l}\text { Least-squares fit standard deviation for } \mathrm{I}_{\mathrm{TR}}\left(\mathrm{I}_{\mathrm{sc}} \text { of }\right. \\
\text { test device) }\end{array}$ & 0.42 & $\mathrm{~N}=9$ \\
\hline $\mathrm{R}_{\mathrm{T}}$ & $\begin{array}{l}\text { Reference cell } \mathrm{I}^{\mathrm{sc}} \text { to monitor } \mathrm{I}^{\mathrm{sc}} \text { transfer standard } \\
\text { deviation }\end{array}$ & 0.02 & $\mathrm{~N}=30$ \\
\hline \multirow{3}{*}{$\mathrm{U}_{\mathrm{S}}$} & Error from spatial nonuniformity & & Rectangular \\
\hline & $<30-\mathrm{cm} \times 30-\mathrm{cm}$ area & 1.0 & \\
\hline & $>3-\mathrm{cm} \times 30-\mathrm{cm}$ area & 3.0 & \\
\hline $\mathrm{U}_{\mathrm{M}}$ & Error in the spectral correction factor $\mathrm{M}$ & 0.4 & Gaussian \\
\hline $\mathrm{U}_{\mathrm{Isc}}$ & Uncertainty in test device $\mathrm{I}_{\mathrm{sc}}$ & & coverage $=2$ \\
\hline
\end{tabular}




\begin{tabular}{|c|c|c|c|}
\hline $\begin{array}{l}\text { Uncertainty } \\
\text { Component }\end{array}$ & Source of Uncertainty & $\begin{array}{c}\text { Value of } \\
\text { Uncertainty } \\
(\%)\end{array}$ & $\begin{array}{l}\text { Coverage } \\
\text { Factor }\end{array}$ \\
\hline & $<30 \mathrm{~cm} \times 30 \mathrm{~cm}$ area & 1.67 & \\
\hline & $>30-\mathrm{cm} \times 30-\mathrm{cm}$ area & 3.67 & \\
\hline $\mathrm{U}_{\text {P-fit }}$ & Error in $\mathrm{P}_{\max }$ from the fit & 0.06 & Gaussian \\
\hline $\mathrm{U}_{\mathrm{TV}}$ & Test device voltage for $\pm 2^{\circ} \mathrm{C}$ & 1.00 & Rectangular \\
\hline $\mathrm{U}_{\mathrm{V}}$ & Measured test device voltage & 0.008 & Rectangular \\
\hline $\mathrm{U}_{\mathrm{Vmax}}$ & Maximum power voltage & 1.6 & coverage $=2$ \\
\hline \multirow[t]{3}{*}{$\mathrm{U}_{\mathrm{Imax}}$} & Maximum power current & & coverage $=2$ \\
\hline & $<30-\mathrm{cm} \times 30-\mathrm{cm}$ area & 1.4 & \\
\hline & $>30-\mathrm{cm} \times 30-\mathrm{cm}$ area & 3.5 & \\
\hline \multirow[t]{3}{*}{$\mathrm{U}_{\mathrm{Pmax}}$} & Maximum power & & coverage $=2$ \\
\hline & $<30-\mathrm{cm} \times 30-\mathrm{cm}$ area & 2.03 & \\
\hline & $>30-\mathrm{cm} \times 30-\mathrm{cm}$ area & 3.85 & \\
\hline $\mathrm{U}_{\mathrm{Voc}}$ & Open-circuit voltage & 1.16 & coverage $=2$ \\
\hline $\mathrm{U}_{\mathrm{A}}$ & Area & 0.63 & coverage $=2$ \\
\hline \multirow[t]{3}{*}{$\mathrm{U}_{\eta}$} & Efficiency & & coverage $=2$ \\
\hline & $<30-\mathrm{cm} \times 30-\mathrm{cm}$ area & 2.13 & \\
\hline & $>30-\mathrm{cm} \times 30-\mathrm{cm}$ area & 3.90 & \\
\hline $\mathrm{U}_{\mathrm{FF}}$ & Fill factor & 1.19 & coverage $=2$ \\
\hline
\end{tabular}

\subsection{Uncertainty in $I_{s c}$}

The uncertainty in the short-circuit current of the reference cell, $I_{T R}$ from Eq. 4, is determined using standard uncertainty analysis based on [11-13]. For convenience, the elemental Type A and Type B error sources will be expressed in terms of percentage of value. The analysis is based on the best measurement capability and represents the smallest uncertainty of nearly ideal PV reference devices. This means that the devices should be stable with no measurable degradation, packaged with wires and temperature sensors, and close to $10 \mathrm{~cm}$ by $10 \mathrm{~cm}$. For samples with one side larger than $30 \mathrm{~cm}$, an additional spatial nonuniformity error must be considered. Combining Eqs. 3 and 4 yields

$I_{T R}=\left(I_{T M} I_{M M^{\prime}} I_{R R}\right) /\left(M I_{R M} I_{M M}\right)$

To express the uncertainty as a percentage, a typical I-V case is used so the voltmeter range and resolution can be converted to a percentage. The I-V curves are shown for the typical small-area case (Fig. 16) and medium-area case (Fig. 17). The analysis will be based on the larger module sample, with the exception of an area-dependent spatial nonuniformity term. 


\section{Solec}

mono-Si module

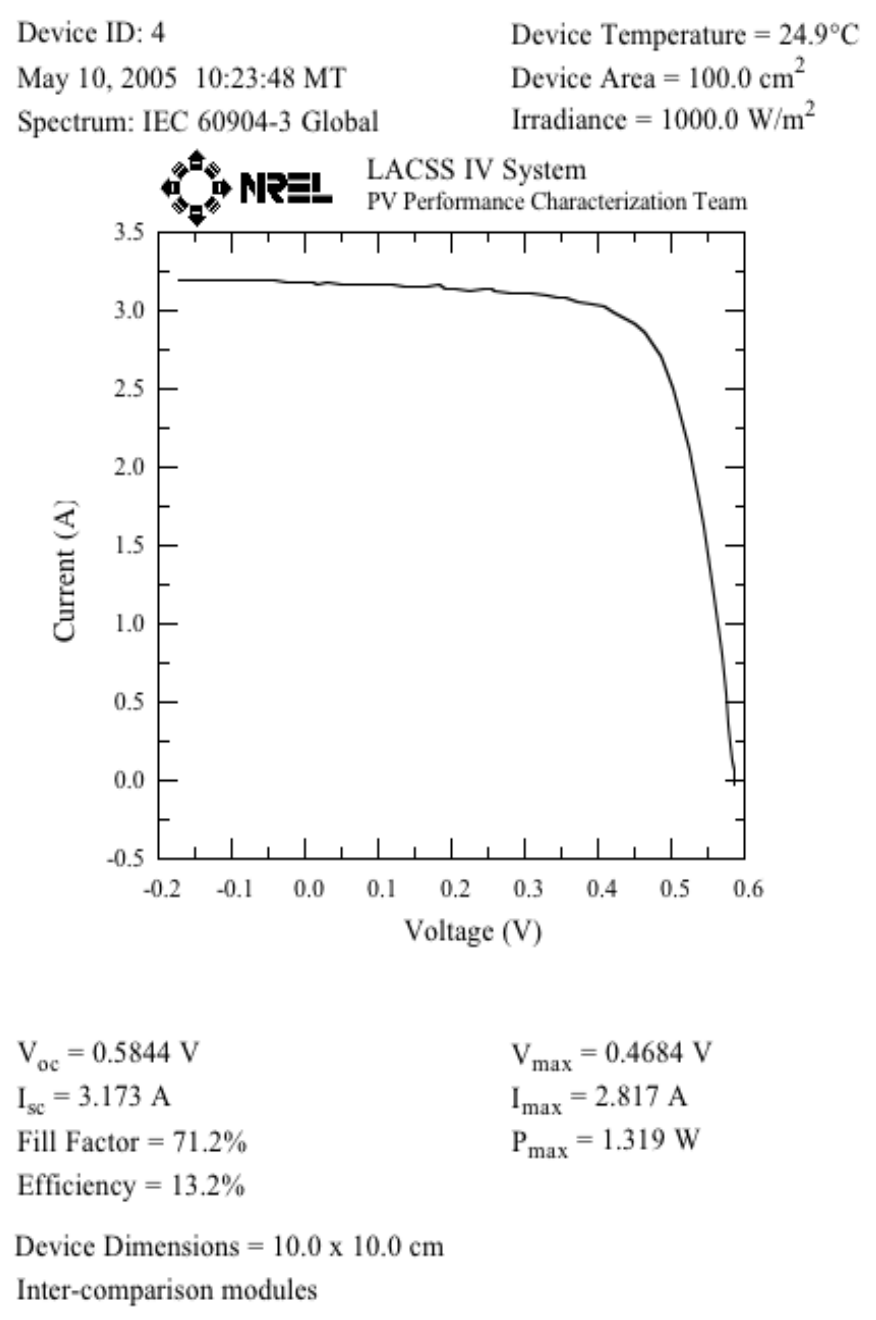

Figure 16. Typical I-V curve for a cell in module package test device.

The measured monitor value $I_{M M}$, or $I_{M M}$, is the voltage measured across a 0.1 -ohm resistor with an Agilent 34401A multimeter. The integration period for step 5.3 is 10 line cycle and contributes no additional error, while the integration period in step 5.7 is at 1 line cycle and introduces an additional $0.001 \%$ error of range. The measured monitor voltage is typically 94 $\mathrm{mV}$. An op-amp circuit is used to bias the monitor cell within $2 \mathrm{mV}$ of $0 \mathrm{~V}$ and monitor the current with a 1-ohm 4-terminal resistor (Appendix 2). From the 1-year manufacturer's specification, the uncertainty on the Agilent $34401 \mathrm{~A}$ voltmeter $100-\mathrm{mV}$ range is $0.0050 \%$ of the reading plus $0.0035 \%$ of the range plus $0.001 \%$ of range because the power-line cycle was not longer than 1 . The meter uncertainties supplied by the manufacturer are based on a $23 \pm 5^{\circ} \mathrm{C}$ operating temperature. Since the resistors and meters are in a temperature-controlled room at 


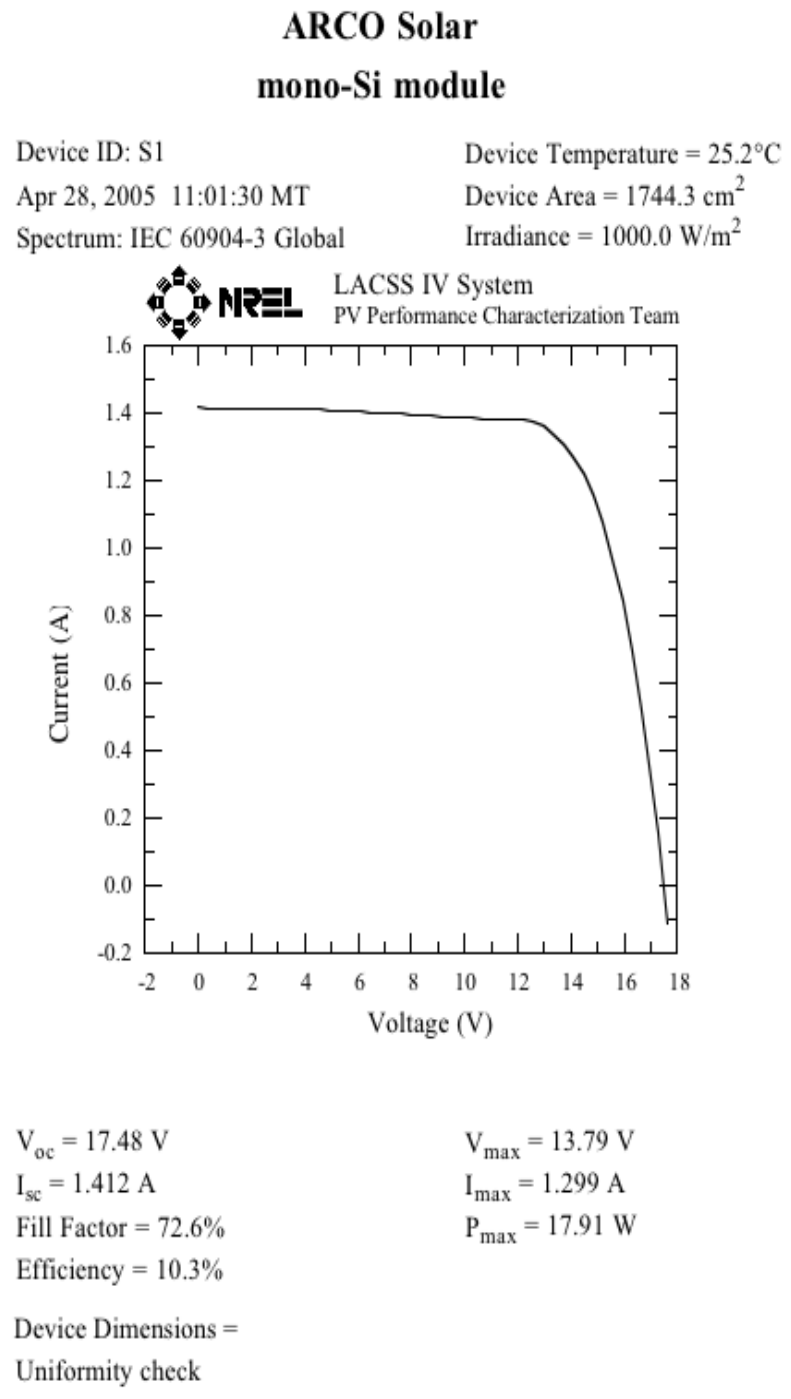

Figure 17. Typical I-V curve for a module test device.

$23 \pm 15^{\circ} \mathrm{C}$, the maximum expected resistor and meter temperature deviation is $23 \pm 15^{\circ} \mathrm{C}$. The temperature coefficient of the meter outside of the $23 \pm 15^{\circ} \mathrm{C}$ is $0.0005 \% /{ }^{\circ} \mathrm{C}$ of reading and $0.0001 \% /{ }^{\circ} \mathrm{C}$ of range for $1-\mathrm{V}$ range. The total error of the voltage reading across the 1 -ohm current sense resistor $U_{M-D M M}$ is

$$
\begin{aligned}
& \begin{aligned}
U_{M-D M M} & =[\% \text { of reading }+ \text { temperature correction }]+[\% \text { of range }+ \text { temperature correction }] \\
& =100 \cdot\{[(0.005+15 \bullet 0.005) \cdot 0.01 \cdot 0.094]+ \\
& {[(0.0035+0.001+15 \cdot 0.005) \cdot 0.01 \cdot 0.1]\} / 0.094=0.018 \% . }
\end{aligned} \\
& U_{M-D M M}=0.019 \% \text { for } 1-\text { line cycle in step } 5.7
\end{aligned}
$$


The temperature coefficient of the 1-ohm resistor manufactured by Electro Scientific Industries Corporation (ESI) is $15 \mathrm{ppm} /{ }^{\circ} \mathrm{C}$ or $0.0015 \% /{ }^{\circ} \mathrm{C}$. The uncertainty of the 1 -ohm ESI resistor calibration is $0.02 \%$. The 1 -year stability of the resistor is taken as $20 \mathrm{ppm} / \mathrm{year}$ because the resistors have been in use for more than 10 years. The power rating of the resistor is $6 \mathrm{~W}$ and the power dissipated across the resistor is $\left(1 \mathrm{ohm} \cdot 0.0252 \mathrm{~A}^{2}=0.6 \mathrm{~mW}\right)$, so resistor heating is negligible. Hence, $U_{M M}$ and $U_{M M}$, the uncertainties in $I_{M M}$ and $I_{M M}$, respectively, are taken to be

$$
\begin{aligned}
& U_{M M}, U_{M M^{\prime}}=\left[\left(U_{M-D M M}\right)^{2}+\left(T_{\text {resistor }} \cdot T_{\text {coeficient-resistor }}\right)^{2}+\left(U_{\text {resistor }}\right)^{2}+\left(U_{\text {stability }}\right)^{2}\right]^{0.5} \\
& U_{M M}, \quad=0.029 \%=\left[0.018^{2}+(0.0015 \cdot 15)^{2}+0.02^{2}+0.02^{2}\right]^{0.5} \\
& U_{M M}=0.028 \%=\left[0.019^{2}+(0.0015 \cdot 15)^{2}+0.02^{2}+0.02^{2}\right]^{0.5}
\end{aligned}
$$

The distribution is taken to be rectangular in the absence of further information.

The primary reference cell measured short-circuit current $I_{R M}$ in step 5.3 is the voltage measured across a 1-ohm resistor with an Agilent 34401A multimeter with 10-power-line cycle integration period. The circuit used to bias the reference cell within $2 \mathrm{mV}$ of $0 \mathrm{~V}$ is described in Appendix 2. The reference cell current at standard reporting conditions is typically $101 \mathrm{~mA}$. From the 1-year manufacturer's specification, the uncertainty on the $100-\mathrm{mV}$ range is $0.0050 \%$ of the reading plus $0.0035 \%$ of the range. The meter uncertainties are based on a $23 \pm 15^{\circ} \mathrm{C}$ operating temperature. The total error of the voltage reading $U_{R-D M M}$ is

$$
\begin{aligned}
U_{R-D M M} & =[\% \text { of reading }+ \text { temperature correction }]+[\% \text { of range }+ \text { temperature correction }] \\
& =100 \cdot\{[(0.0050+15 \cdot 0.005) \cdot 0.01 \cdot 0.101]+ \\
& {[0.0035+(15 \cdot 0.005) \cdot 0.01 \cdot 0.1]\} / 0.101 } \\
& =0.017 \% .
\end{aligned}
$$

The uncertainty of the $1-\mathrm{ohm}$ resistor calibration is $0.02 \%$. The resistor temperature coefficient is negligible at $15 \mathrm{ppm} /{ }^{\circ} \mathrm{C}=0.0015 \% /{ }^{\circ} \mathrm{C}$. The 1 -year stability of the resistor is taken as 20 $\mathrm{ppm} /$ year because the resistors have been in use for more than 10 years. The power rating of the resistor is $6 \mathrm{~W}$ and the power dissipated across the resistor is $\left(1 \mathrm{ohm} \cdot 0.132 \mathrm{~A}^{2}=17 \mathrm{~mW}\right)$, so resistor heating is negligible. Hence, the uncertainty $U_{R M}$ in $I_{R M}$ is taken to be

$$
\begin{aligned}
U_{R M} & =\left(U_{R-D M M}\right)^{2}+\left(T_{\text {resistor }} \cdot T_{\text {coeficient-resistor }}\right)^{2}+\left(U_{\text {resistor }}\right)^{2}+\left(U_{\text {stability }}\right)^{2} \\
& =\left[0.017^{2} \cdot(0.0015 \cdot 15)^{2}+0.002^{2}+0.02^{2}\right]^{0.5} \\
& =0.028 \% .
\end{aligned}
$$

The distribution is taken to be rectangular in the absence of further information.

The measured current of the device under test $I_{T M}$ is the voltage measured across a current sense resistor with an Agilent 34401A multimeter with 1-power-line cycle integration period, as shown in Fig. 15. Depending on the current range and current limit, a particular resistor is selected to maintain between 10 and $100 \mathrm{mV}$ across the resistor. The precision 4-terminal low-temperaturecoefficient Riedon resistors are nominally $0.001,0.01,0.1,1.0$, and 10 ohms. A typical shortcircuit current for a test device is $1.41 \mathrm{~A}$. So, the software would select the $100-\mathrm{mV}$ range and a 0.01-ohm current sense resistor. This is near the worst-case scenario, being at the low end of the meter 100-mV range. From the 1-year 34401A manufacturer's specification, the uncertainty on the $1-\mathrm{V}$ range is $0.0050 \%$ of the reading plus $0.0035 \%$ of the range plus $0.001 \%$ of range 
because the power-line cycle was not longer than 1 . The meter uncertainties are based on a $23 \pm 15^{\circ} \mathrm{C}$ operating temperature $\left(0.005 \% /{ }^{\circ} \mathrm{C}\right)$. The total error $U_{I-D M M}$ of the voltage reading is

$$
\begin{aligned}
U_{I-D M M} & =[\% \text { of reading }+ \text { temperature correction }]+[\% \text { of range }+ \text { temperature correction }] \\
& =100 \cdot\{[(0.0050+15 \cdot 0.005) \cdot 0.01 \cdot 0.0141]+ \\
& {[(0.0035+0.001+0.0075) \cdot 0.01 \cdot 0.1]\} / 0.0141=0.055 \% }
\end{aligned}
$$

The uncertainty of the Riedon Corporation model PF1238 $0.01 \mathrm{ohm}$ resistor calibration is $0.02 \%$. The resistor temperature coefficient is negligible at $20 \mathrm{ppm} /{ }^{\circ} \mathrm{C}=0.0020 \% /{ }^{\circ} \mathrm{C}$. The 1 -year stability of the resistor is specified as $0.1 \% /$ year. The power rating of the Riedon resistor is 60 $\mathrm{W}$ and the power dissipated across the resistor is $\left[0.01 \mathrm{ohm} \cdot(1.412 \mathrm{~A})^{2}=20 \mathrm{~mW}\right]$, so resistor heating is negligible. Hence, $U_{T M}$, the uncertainty in $I_{T M}$, is taken to be

$$
\begin{gathered}
U_{T M}=\left[\left(U_{I-D M M}\right)^{2}+\left(T_{\text {resistor }} \cdot T_{\text {coeficient-resistor }}\right)^{2}+\left(U_{\text {resistor }}\right)^{2}+\left(U_{\text {stability }}\right)^{2}\right]^{0.5} \\
=\left[0.055^{2}+(0.0020 \cdot 15)^{2}+\left(0.02^{2}+0.10^{2}\right)\right]^{0.5}=0.120 \%
\end{gathered}
$$

The distribution is taken to be rectangular in the absence of further information.

The uncertainty in the reference cell, $I_{R R}$, has been determined elsewhere and confirmed by international intercomparisons to be less than $1 \%$ with $0.91 \%$ estimated as $\mathrm{U}_{95}$ from uncertainty analysis [14-24].

There is an uncertainty in $I_{R M}$ and $I_{T M}$ because of temperature. The important parameter is how close the measured temperature of the reference cell and test device is to the reference temperature. The reference temperature is typically $25^{\circ} \mathrm{C}$ and the temperature is within $\pm 5^{\circ} \mathrm{C}$. Assuming a typical short-circuit temperature coefficient of $0.05 \% /{ }^{\circ} \mathrm{C}$ gives $0.25 \%$ for the temperature uncertainty of the test device $U_{T T}$ and reference cell $U_{T R}$.

There is an additional uncertainty in $I_{T M}, U_{S}$, because the light in the test plane is not spatially uniform. This error is a function of the size of the reference cell compared with the test device and how close the monitor is to the device under test. The spatial uniformity also changes with intensity fluctuations. This error source varies from set-up to set-up. But only one measurement of transfer calibration and one set-up is performed to obtain $I_{M R}$, so this error is a Type B error source with a rectangular distribution. Figure 18 shows a typical spatial nonuniformity map of the large-area continuous solar simulator (LACSS). For the $55-\mathrm{cm}$ by $32-\mathrm{cm}$ approximate area for the example, the uncertainty in $\mathrm{U}_{\mathrm{S}}$ is estimated to be $3 \%$. 
LACSS Spatial Uniformity 10-20-04

(148.3 hrs, 51 Starts, CSP 419A, Baseline)

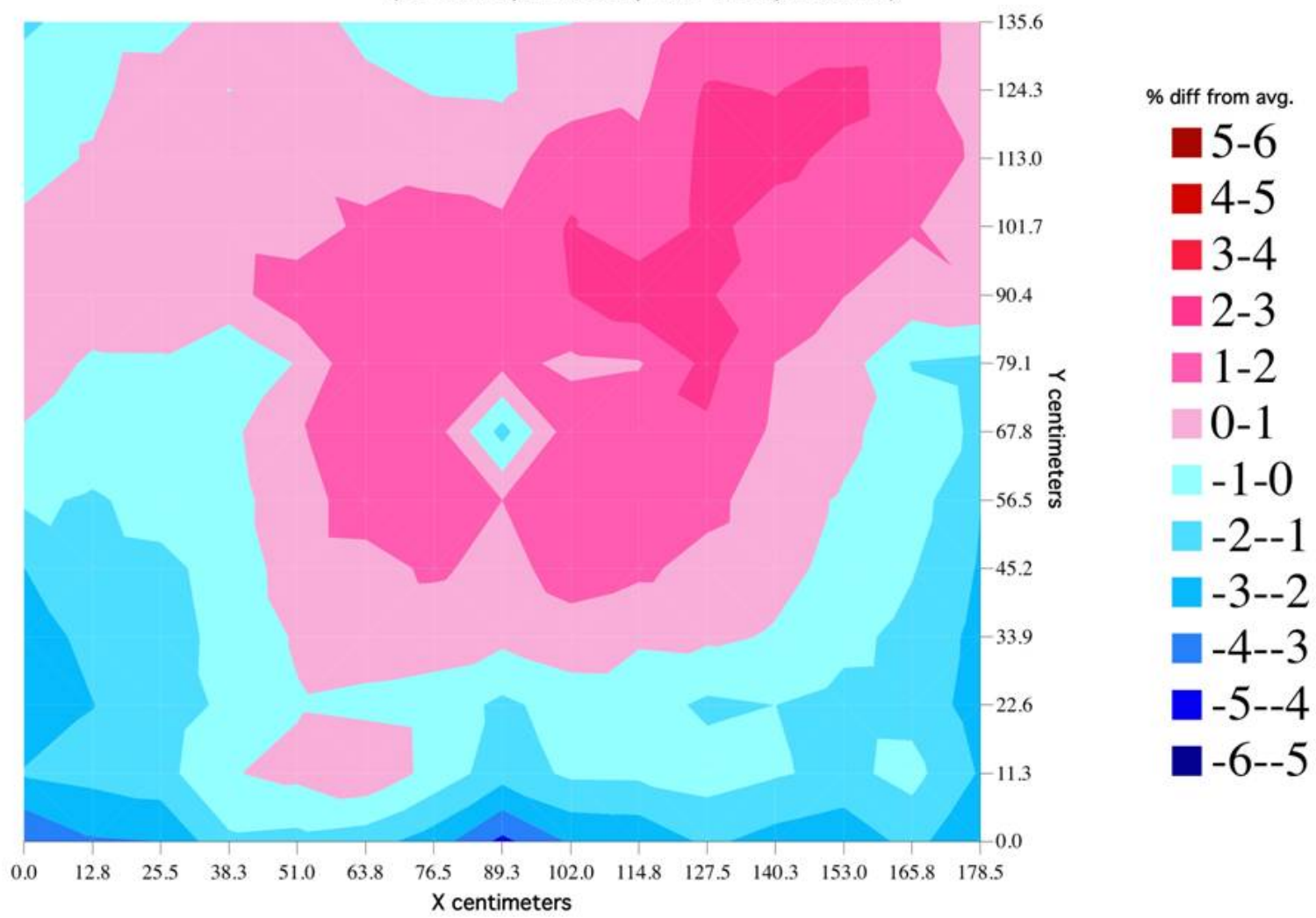

Figure 18. Typical spatial nonuniformity of large-area continuous solar simulator showing $\pm 1 \%$ for areas less than $30 \mathrm{~cm}$ by $30 \mathrm{~cm}$; if a $10-\mathrm{cm}$ by $10-\mathrm{cm}$ cell is used, then the nonuniformity is $\pm 0.5 \%$. For larger modules, the spatial nonuniformity is typically $\pm 3 \%$.

Type A error sources arise from the calibration of the intensity monitor $I_{M R}$ and a least-squares fit to the restricted $\mathrm{I}-\mathrm{V}$ data set to obtain $\mathrm{I}_{\mathrm{TR}}$. The standard deviation $R_{T}$ for $I_{M R}$, is typically $0.02 \%$ with the number of readings averaged equal to 30. The standard deviation for $I_{T R}\left(I_{S c}\right)$ in Fig. 16 is $R_{C}=0.042 \%$ for a fit to nine I-V points. This is the standard deviation of the intercept [12]. The uncertainty in the voltage in the linear regression is taken to be zero because the intercept is the parameter of interest and the voltage is measured at the same time (group trigger) with the same model of meter (34401A) and has an estimated uncertainty of less than $1 \mathrm{mV}$ or $0.006 \%$. All other error sources are Type B because they do not involve averages of repeated measurements.

The uncertainty in the spectral correction factor $M$ is a function of the magnitude of $\mathrm{M}[13,22]$. A conservative estimate of the uncertainty in $M$ is $20 \%$ of the value of $\mathrm{M}[16,25]$. Since the restrictions on the devices make $M$ less than $2 \%$ (0.98 to 1.02), then the uncertainty in $M$ is taken to be $U_{M}=0.40 \%$. This is less than the uncertainty for the outdoor calibrations because the spectral irradiance over the entire range of the cavity radiometer is less well known. For simulator measurements, the spectral irradiance is measured over the entire response range of the PV test device and reference cell. The distribution is taken to be normal (Gaussian) based on Monte Carlo perturbation analysis [16,25]. 
The expanded uncertainty with $95 \%$ confidence (coverage $=2$ ) in the short-circuit current is

$$
\begin{aligned}
& U_{I_{s c}}=2\left[\begin{array}{l}
\left(\frac{U_{T M}}{\sqrt{3}}\right)^{2}+\left(\frac{U_{M M}}{\sqrt{3}}\right)^{2}+\left(\frac{U_{M M}}{\sqrt{3}}\right)^{2}+\left(\frac{U_{R R}}{\sqrt{3}}\right)^{2}+\left(\frac{U_{R M}}{\sqrt{3}}\right)^{2} \\
+\left(\frac{R_{T}}{\sqrt{30}}\right)^{2}+\left(\frac{R_{C}}{\sqrt{9}}\right)^{2}+\left(\frac{U_{T T}}{\sqrt{3}}\right)^{2}+\left(\frac{U_{T R}}{\sqrt{3}}\right)^{2}+\left(\frac{U_{S}}{\sqrt{3}}\right)^{2}+\left(\frac{U_{M}}{2}\right)^{2}
\end{array}\right]^{0.5} \\
& U_{I_{s c}}=2\left[\begin{array}{l}
\left(\frac{0.120}{\sqrt{3}}\right)^{2}+\left(\frac{0.029}{\sqrt{3}}\right)^{2}+\left(\frac{0.028}{\sqrt{3}}\right)^{2}+\left(\frac{0.91}{\sqrt{3}}\right)^{2}+\left(\frac{0.028}{\sqrt{3}}\right)^{2} \\
+\left(\frac{0.02}{\sqrt{30}}\right)^{2}+\left(\frac{0.042}{\sqrt{9}}\right)^{2}+\left(\frac{0.25}{\sqrt{3}}\right)^{2}+\left(\frac{0.25}{\sqrt{3}}\right)^{2}+\left(\frac{3.0}{\sqrt{3}}\right)^{2}+\left(\frac{0.4}{2}\right)^{2}
\end{array}\right] \\
& \mathrm{U}_{\mathrm{Isc}}=3.67 \% \text { for spatial nonuniformity of } \pm 3 \% \\
& \mathrm{U}_{\mathrm{Isc}}=1.67 \% \text { for spatial nonuniformity of } \pm 1 \% .
\end{aligned}
$$

\subsection{Uncertainty in $P_{\max }$}

The maximum power, $P_{\max }$, is defined as the maximum of the product of the current and voltage under standard reporting conditions. The maximum power is a function of contacting because of the distributed resistance nature of photovoltaics. The uncertainty from this error source is zero because the analysis assumes that separate voltage and current wires are attached to the device. The current at $P_{\max }$ is defined as $I_{\max }$, while the voltage at $P_{\max }$ is $V_{\max }$. The largest measured power may not be the maximum power because of noise on the measured current versus voltage. For this reason, the maximum power is obtained by a polynomial curve fit to a restricted set of data points. The fitting constraints on the restricted $\left(V, I_{T R}\right)$ data are based on the largest measured power $P_{m}$ and the voltage $V_{m}$ at $P_{m}$.

$0.85 \cdot P_{m} \leq P \leq 1.15 \cdot P_{m}$

and

$0.8 \cdot V_{m} \leq V \leq 1.2 \cdot V_{m}$,

where $P$ is the product of the measured voltage and corrected current $I_{T R}$. This procedure reduces the uncertainty in the "true" maximum power by allowing least-squares polynomial curve-fitting to "average" over multiple data points. The uncertainty $U_{P-f i t}$ in the fit of the restricted current versus voltage data $U_{P \max }$ was determined to be less than $0.06 \%$ by modeling the $I-V$ data of the test case using the standard diode equation with series and shunt resistance and a similar number of points in the fit and introducing a random error in the current until the mean square error of the fit was within $1 \%$ of the actual measured data and modeled data. The temperature coefficient of the voltage was assumed to be $0.5 \% /{ }^{\circ} \mathrm{C}$ giving $U_{T V}$. Since the data are not corrected for temperature, the error in the power is a function of the deviation from the reference temperature. In this analysis, the deviation of "true" device temperature from the reference temperature is 
assumed to be $\pm 2{ }^{\circ} \mathrm{C}$. The error in the voltage meter $U_{V}$ is based on the average of two voltage readings at 1-line-cycle integration period and a voltage of $17.48 \mathrm{~V}$ (from Fig. 16).

$$
\begin{aligned}
U_{V}= & {[\% \text { of reading }+ \text { temperature correction }]+[\% \text { of range }+ \text { temperature correction }] } \\
& =100 \cdot\{[(0.0045+0.0075) \cdot 0.01 \cdot 17.48]+ \\
& {[(0.0006+0.001+0.0075) \cdot 0.01 \cdot 100]\} / 17.48=0.024 \% }
\end{aligned}
$$

The expanded uncertainty with $95 \%$ confidence (coverage $=2$ ) in the maximum power is

$$
\begin{aligned}
& U_{P_{\max }}=2\left[\begin{array}{l}
\left.\left(\frac{U_{T M}}{\sqrt{3}}\right)^{2}+\left(\frac{U_{M M}}{\sqrt{3}}\right)^{2}+\left(\frac{U_{M M^{\prime}}}{\sqrt{3}}\right)^{2}+\left(\frac{U_{R R}}{\sqrt{3}}\right)^{2}+\left(\frac{U_{R M}}{\sqrt{3}}\right)^{2}+\left(\frac{R_{T}}{\sqrt{30}}\right)^{2}+\left(\frac{R_{C}}{\sqrt{9}}\right)^{2}\right]^{0.5} \\
+\left(\frac{U_{T T}}{\sqrt{3}}\right)^{2}+\left(\frac{U_{T R}}{\sqrt{3}}\right)^{2}+\left(\frac{U_{S}}{\sqrt{3}}\right)^{2}+\left(\frac{U_{M}}{2}\right)^{2}+\left(\frac{U_{P-f i t}}{2}\right)^{2}+\left(\frac{U_{T V}}{\sqrt{3}}\right)^{2}+\left(\frac{U_{V}}{\sqrt{3}}\right)^{2}
\end{array}\right]^{2} \\
& U_{P_{\max }}=2\left[\begin{array}{l}
\left(\frac{0.120}{\sqrt{3}}\right)^{2}+\left(\frac{0.029}{\sqrt{3}}\right)^{2}+\left(\frac{0.028}{\sqrt{3}}\right)^{2}+\left(\frac{0.91}{\sqrt{3}}\right)^{2}+\left(\frac{0.028}{\sqrt{3}}\right)^{2}+\left(\frac{0.020}{\sqrt{30}}\right)^{2}+\left(\frac{0.042}{\sqrt{9}}\right)^{2} \\
+\left(\frac{0.50}{\sqrt{3}}\right)^{2}+\left(\frac{0.50}{\sqrt{3}}\right)^{2}+\left(\frac{3}{\sqrt{3}}\right)^{2}+\left(\frac{0.4}{2}\right)^{2}+\left(\frac{0.060}{2}\right)^{2}+\left(\frac{0.5}{\sqrt{3}}\right)^{2}+\left(\frac{0.024}{\sqrt{3}}\right)^{2}
\end{array}\right]^{2}
\end{aligned}
$$

$\mathrm{U}_{\mathrm{Pmax}}=3.85 \%$ for spatial nonuniformity of $\pm 3 \%$

$\mathrm{U}_{\mathrm{Pmax}}=2.03 \%$ for spatial nonuniformity of $\pm 1 \%$.

The uncertainty in $V_{\max }$ and $I_{\max }$ can be conservatively estimated to be less than the uncertainty in $P_{\max }$ and greater than the uncertainty in $I_{s c}$. A more accurate estimate is difficult because of the sample-specific nonanalytic nonlinear relationship between the uncertainty $P_{\max }, I_{\max }$, and $V_{\max }$. The uncertainty in $V_{\max }$ is greater than the uncertainty in $V_{o c}$ because of additional resistancerelated error sources. Hence,

$\mathrm{U}_{\text {Imax }}=3.5 \%$ for spatial nonuniformity of $\pm 3 \%$

$\mathrm{U}_{\text {Imax }}=1.4 \%$ for spatial nonuniformity of $\pm 1 \%$

and

$U_{V_{\max }}=1.6 \%$

\subsection{Uncertainty in $\mathrm{V}_{\mathrm{oc}}$}

The open-circuit voltage is measured with the device open-circuited with a single 10-line-cycle integration period reading (17.48 V from Fig. 16). The dominant error is from a $\pm 2{ }^{\circ} \mathrm{C}$ uncertainty in temperature resulting in an uncertainty in the voltage $U_{T V}$. The $V_{o c}$ error from an error in the irradiance is assumed to be zero because the irradiance is constrained to be within $\pm 2 \%$ of standard reference conditions by procedures. This error is a function of the device and is logarithmic in nature. 


$$
\begin{aligned}
& U_{V}= {[\% \text { of reading }+ \text { temperature correction }]+[\% \text { of range }+ \text { temperature correction }] } \\
&=100 \cdot\{[(0.0045 \%+0.0075) \cdot 0.01 \cdot 17.48]+ \\
& {[(0.006+0.001+0.0075) \cdot 0.01 \cdot 100]\} / 17.48=0.030 \% . } \\
& U_{V_{o c}}=2\left[\left(\frac{U_{T V}}{\sqrt{3}}\right)^{2}+\left(\frac{U_{V}}{2}\right)^{2}\right]^{0.5} \\
& U_{V_{o c}}=2\left[\left(\frac{1.0}{\sqrt{3}}\right)^{2}+\left(\frac{0.030}{\sqrt{3}}\right)^{2}\right]^{0.5} \\
& U_{V_{o c}}= 1.16 \% .
\end{aligned}
$$

\subsection{Uncertainty in Area}

Two components of the uncertainty in the area are related to the subjective interpretation of the edge of the device and the ability to measure the distance between edges. We consider the rectangular module used in this analysis with dimensions area of $55 \mathrm{~cm}$ by $32 \mathrm{~cm}$.

Hence, the uncertainty in the area can be determined from the average of eight distance measurements. The values are measured with a resolution of 1-mm uncertainty in the distance. Hence, the uncertainty in the distance measurement is

$$
U_{A}=2\left\{\left[100 \bullet 0.1 /\left(55 \cdot 3^{0.5}\right)\right]^{2}+\left[100 \bullet 0.1 /\left(32 \cdot 3^{0.5}\right)\right]^{2}\right\}^{0.5}=0.41 \% \text {. }
$$

It is estimated that there is an additional 1-mm uncertainty due to operator judgment, which gives an additional $0.41 \%$ uncertainty. The resulting uncertainty in the area is $0.63 \%$.

\subsection{Uncertainty in Efficiency}

The efficiency with respect to standard reference conditions defined by a temperature, spectral, and total irradiance can be written as

$$
\eta=100 \frac{P_{\max }}{E_{r e f} A} .
$$

The uncertainty in $\eta$ can be written as

$$
\begin{aligned}
& U_{\eta}=2\left[\left(\frac{U_{A}}{\sqrt{3}}\right)^{2}+\left(\frac{U_{P_{\max }}}{\sqrt{3}}\right)^{2}\right]^{0.5} \\
& U_{\eta}=2\left[\left(\frac{0.63}{1.73}\right)^{2}+\left(\frac{3.85}{1.73}\right)^{2}\right]^{0.5}=3.90 \% \text { for spatial nonuniformity of } \pm 3 \% \\
& U_{\eta}=2\left[\left(\frac{0.63}{1.73}\right)^{2}+\left(\frac{2.03}{1.73}\right)^{2}\right]^{0.5}=2.13 \% \text { for spatial nonuniformity of } \pm 1 \% .
\end{aligned}
$$




\subsection{Uncertainty in Fill Factor}

The fill factor, $F F$, is defined as

$$
F F \equiv 100 \frac{P_{\max }}{V_{o c} I_{s c}}
$$

The uncertainty $U_{F F}$ in FF can be written as

$$
U_{F F}=2\left[\left(\frac{U_{P_{\max }}}{2}\right)^{2}+\left(\frac{U_{V_{o c}}}{2}\right)^{2}+\left(\frac{U_{I_{s c}}}{2}\right)^{2}\right]^{0.5}=2\left[\left(\frac{3.85}{2}\right)^{2}+\left(\frac{1.16}{2}\right)^{2}+\left(\frac{3.67}{2}\right)^{2}\right]^{0.5}=5.44 \% \text {, }
$$

assuming that $V_{o c}, I_{s c}$, and $P_{\max }$ are not correlated. In fact, to a first order, increasing $I_{s c}$ by a given percentage due to spatial nonuniformity, reference cell uncertainty or other factors will increase $P_{\max }$ by the same percentage. Furthermore, the constraints on the measurement require that the fill factor be measured within $2 \%$ of the correct irradiance. For devices that are not series resistance-limited, a $2 \%$ variation in intensity will have a negligible effect on the fill factor. A more realistic estimate of the uncertainty in FF would be to remove all terms related to the uncertainty in the irradiance. The sign on the voltage temperature coefficient of FF is in the same direction and similar magnitude for $\mathrm{V}_{\mathrm{oc}}$ and $\mathrm{P}_{\max }$, effectively counting the temperaturedependence twice. This leaves errors related to temperature, current measurement meter, voltage measurement meter, and curve fits.

$$
\begin{aligned}
& U_{F F}=2\left[\left(\frac{U_{T V}}{\sqrt{3}}\right)^{2}+\left(\frac{U_{V}}{\sqrt{3}}\right)^{2}+\left(\frac{U_{V-D M M}}{\sqrt{3}}\right)^{2}+\left(\frac{U_{I-D M M}}{\sqrt{3}}\right)^{2}+\left(\frac{U_{M-D M M}}{\sqrt{3}}\right)^{2}+\left(\frac{U_{T T}}{\sqrt{3}}\right)^{2}+\left(\frac{R_{C}}{\sqrt{9}}\right)^{2}+\left(\frac{U_{P-f i t}}{2}\right)^{2}\right]^{0.5} \\
& U_{F F}=2\left[\left(\frac{1.00}{\sqrt{3}}\right)^{2}+\left(\frac{0.030}{\sqrt{3}}\right)^{2}+\left(\frac{0.017}{\sqrt{3}}\right)^{2}+\left(\frac{0.055}{\sqrt{3}}\right)^{2}+\left(\frac{0.018}{\sqrt{3}}\right)^{2}+\left(\frac{0.10}{\sqrt{3}}\right)^{2}+\left(\frac{0.030}{\sqrt{9}}\right)^{2}+\left(\frac{0.06}{2}\right)^{2}\right]^{0.5} \\
& U_{F \mathrm{~F}}=1.19 \% .
\end{aligned}
$$

\section{References for Section 5}

1. ASTM Standard E1036, Standard Test Methods for Electrical Performance of Nonconcentrator Terrestrial Photovoltaic Modules and Arrays Using Reference Cells, Amer. Society for Testing Matls., West Conshocken PA, USA.

2. ASTM Standard 1040, Specification for Physical Characteristics of Non-Concentrator Photovoltaic Reference Cells, Amer. Society for Testing Matls., West Conshocken PA, USA.

3. ASTM Standard G159, Standard Tables for Reference Solar Spectral Irradiances: Direct Normal and Hemispherical on $37^{\circ}$ Tilted Surfaces, Amer. Society for Testing Matls., West Conshocken PA, USA.

4. IEC Standard 60904-3, Measurement Principles for Terrestrial Photovoltaic (PV) Solar Devices with Reference Spectral Irradiance Data, International Electrotechnical Commission, Geneva, Switzerland. 
5. K. Emery, D. Dunlavy, H. Field, , T. Moriarty, L. Ottoson, and S. Rummel, "PV Cell and Module Characterization Capabilities at NREL," Proc. $14^{\text {th }}$ NREL/SNL Photovoltaics Program Review, Nov. 18-22, 1996, Lakewood, CO.

6. S. Rummel, K. Emery, H. Field, T. Moriarty, A. Anderberg, D. Dunlavy, and L. Ottoson, "PV Cell and Module Performance Measurement Capabilities at NREL," Proc. $15^{\text {th }}$ NCPV Program Review Meeting, Denver, CO, September 8-11, 1998, AIP Proceedings CP-462, pp.553-558, 1998.

7. K.A. Emery, C.R. Osterwald, T.W. Cannon, D.R. Myers, J. Burdick, T. Glatfelter, W. Czubatyj, and J. Yang, "Methods for Measuring Solar Cell Efficiency Independent of Reference Cell or Light Source," Proc. 18 th IEEE Photovoltaic Spec. Conf., Las Vegas, NV, October 21-25, 1985, pp.623-628, IEEE, New York, 1985.

8. ASTM Standard E1328, Standard Terminology Relating to Photovoltaic Solar Energy Conversions, Amer. Society for Testing Matls., West Conshocken PA, USA.

9. ASTM Standard E1021, Standard Test Methods for Measuring Spectral Response of Photovoltaic Cells, Amer. Society for Testing Matls., West Conshocken PA, USA.

10. ASTM Standard E973, Standard Test Method for Determination of the Spectral Mismatch Parameter Between a Photovoltaic Device and a Photovoltaic Reference Cells, Amer. Society for Testing Matls., West Conshocken PA, USA.

11. International Organization for Standardization, Guide to the Expression of Uncertainty in Measurement. ISO: Geneva, 1995, ISBN 92-67-10188-9.

12. M.G. Natrella, "Experimental Statistics,, National Bureau of Standards Handbook 91, p.534. August 1, 1993, reprinted October 1966.

13. "The Expression of Uncertainty and Confidence in Measurement," United Kingdom Accreditation Service, M3003, Middlesex, UK, December 1997.

14. C.R. Osterwald, K.A. Emery, D.R. Myers, and R.E. Hart, "Primary Reference Cell Calibrations at SERI: History and Methods," Proc. $21^{\text {st }}$ IEEE Photovoltaic Specialists Conf., Orlando, FL, May 21-25, 1990, pp.1062-1067, IEEE, New York, 1990.

15. K. A. Emery, C.R. Osterwald, S. Rummel, D.R. Myers, T.L. Stoffel, and D. Waddington, "A Comparison of Photovoltaic Calibration Methods," Proc. $9^{\text {th }}$ European Photovoltaic Solar Energy Conf., Freiburg, W. Germany, September 25-29, 1989, pp.648-651.

16. K.A. Emery, C.R. Osterwald, and C.V. Wells, "Uncertainty Analysis of Photovoltaic Efficiency Measurements," Proc. $19^{\text {th }}$ IEEE Photovoltaic Specialists Conf., New Orleans, LA, May 4-8, pp.153-159, IEEE, New York, 1987.

17. H. Ossenbrink, R. Van Steenwinkel, and K. Krebs, 'The Results of the 1984/1985 RoundRobin Calibration of Reference Solar Cells for the Summit Working Group on Technology, Growth and Employment," Joint Research Center, ISPRA Establishment, ISPRA Italy, Tech Rep. EUR 10613 EN (April 1986).

18. K.A. Emery, C.R. Osterwald, L.L. Kazmerski, and R.E. Hart, "Calibration of Primary Terrestrial References Cells When Compared with Primary AM0 Reference Cells," Proc. $8^{\text {th }}$ European Photovoltaic Solar Energy Conf., Florence, Italy, May 9-12, 1988, pp.64-68.

19. K.A. Emery, D. Waddington, S. Rummel, D.R. Myers, T.L. Stoffel, and C.R. Osterwald, "SERI Results from the PEP 1987 Summit Round Robin and a Comparison of Photovoltaic Calibration Methods," SERI Tech. Rep. TR-213-3472, March 1989.

20. J. Metzdorf, T. Wittchen, K. Heidler, K. Dehne, R. Shimokawa, F. Nagamine, H. Ossenbrink, L. Fornarini, C. Goodbody, M. Davies, K. Emery, and R. Deblasio, "Objectives and Results of the PEP '87 Round-Robin Calibration of Reference Cells and Modules," Proc. $21^{\text {st }}$ IEEE Photovoltaic Specialists Conf., Orlando, FL, May 21-25, 1990, pp.952-959, IEEE, New York, 1990. 
21. J. Metzdorf, T. Wittchen, K. Heidler, K. Dehne, R. Shimokawa, F. Nagamine, H. Ossenbrink, L. Fornarini, C. Goodbody, M. Davies, K. Emery, and R. Deblasio, "The Results of the PEP '87 Round-Robin Calibration of Reference Cells and Modules,- Final Report," PTB Technical Report PTB-Opt-31, Braunschweig, Germany, November 1990, ISBN 3-89429-067-6.

22. C.R. Osterwald, S. Anevsky, A.K. Barua, J. Dubard, K. Emery, D. King, J. Metzdorf, F. Nagamine, R. Shimokawa, N. Udayakumar, Y.X. Wang, W. Zaaiman, A. Zastrow, and J. Zhang, "Results of the PEP '93 Intercomparison of Reference Cell Calibrations and Newer Technology Performance Measurements," Proc. 25 IEEE Photovoltaic Specialists Conf., Washington D.C., May 13-17, 1996, pp.1263-1266, IEEE, New York, 1996.

23. C.R. Osterwald, S. Anevsky, A.K. Barua, J. Dubard, K. Emery, D. King, J. Metzdorf, F. Nagamine, R. Shimokawa, N. Udayakumar, Y.X. Wang, T. Wittchen, W. Zaaiman, A. Zastrow, and J. Zhang, "Results of the PEP'93 Intercomparison of Reference Cell Calibrations and Newer Technology Performance Measurements," Proc. $26^{\text {th }}$ IEEE PVSC Conf., Anaheim, CA. Sept. 29-Oct. 2, 1997, pp.1209-1212, IEEE, New York, 1997.

24. K. Emery, "The Results of the First World Photovoltaic Scale Recalibration," NREL Tech. Rep. NREL/TP-520-27942, (March 2000).

25. H. Field and K. Emery, "An Uncertainty Analysis of the Spectral Correction Factor," Proc. $23^{\text {rd }}$ IEEE Photovoltaic Specialists Conf., Louisville, KY, May 10-14, 1993, pp.11801187, IEEE, New York, 1993. 


\section{GLOSSARY}

\begin{tabular}{|c|c|}
\hline$\eta$ & Efficiency with respect to reference conditions \\
\hline$\lambda$ & Wavelength \\
\hline$A$ & Test cell area \\
\hline$E_{r e f}(\lambda)$ & Reference spectral irradiance \\
\hline$E_{S}(\lambda)$ & Measured spectral irradiance of the light source \\
\hline$E_{t}$ & Total irradiance \\
\hline FF & Fill factor \\
\hline$I_{\max }$ & current at $P_{\max }$ \\
\hline$I_{M M}, I_{M M}$ & Measured the monitor current \\
\hline$I_{M R}$ & Intensity monitor current under reference spectrum and irradiance \\
\hline$I_{R M}$ & Measured reference cell current \\
\hline$I_{R R}$ & Calibrated current of the reference cell under the reference conditions \\
\hline$I_{T M}$ & Measured test cell current \\
\hline$I_{T R}$ & Calibrated current of the test cell under the reference conditions \\
\hline$I-V$ & Current versus voltage \\
\hline$k$ & Spectral correction factor, inverse of $M$ \\
\hline$M$ & Spectral mismatch parameter \\
\hline$P_{\max }$ & Test maximum power under reference conditions \\
\hline $\mathrm{R}_{\mathrm{T}}$ & Standard deviation for $I_{M R}$ \\
\hline$R_{C}$ & Standard deviation for fit to obtain $I_{T R}$ \\
\hline$S_{t}(\lambda)$ & Measured spectral responsivity of the test cell \\
\hline$S_{r}(\lambda)$ & Measured spectral responsivity of the reference cell \\
\hline$U_{I s c}$ & $\begin{array}{l}\text { Combined uncertainty in the short-circuit current of the test cell with respect to } \\
\text { reference conditions }\end{array}$ \\
\hline$U_{\eta}$ & Uncertainty in efficiency \\
\hline$U_{A}$ & Uncertainty in area \\
\hline$U_{F F}$ & Uncertainty in the fill factor \\
\hline$U_{M}$ & Uncertainty in $M$ \\
\hline$U_{M M}, U_{M M}$ & Uncertainty in the short-circuit current of the monitor cell \\
\hline$U_{P \max }$ & Uncertainty in the fit of the restricted current versus voltage data \\
\hline$U_{R M}$ & Uncertainty in measured reference current \\
\hline$U_{R R}$ & $\begin{array}{l}\text { Uncertainty in reference current under reference temperature, spectrum, and } \\
\text { irradiance }\end{array}$ \\
\hline$U_{S}$ & Uncertainty in current related to spatial nonuniformity \\
\hline$U_{T R}$ & Uncertainty in the short-circuit current of the reference cell \\
\hline$U_{T T}$ & Uncertainty in the short-circuit current of the test cell \\
\hline$U_{R R}$ & Uncertainty of the reference cell. \\
\hline$U_{V}$ & Uncertainty in measured voltage \\
\hline$U_{T V}$ & Uncertainty in voltage related to temperature \\
\hline$U_{V o c}$ & Uncertainty in $V_{o c}$ \\
\hline$V$ & Measured test cell voltage \\
\hline$V_{\max }$ & Test cell voltage at $P_{\max }$ \\
\hline$V_{o c}$ & Test cell open-circuit voltage \\
\hline
\end{tabular}




\title{
APPENDIX 1
}

\section{American Association for Laboratory Accreditation}

\author{
SCOPE OF ACCREDITATION TO ISO/IEC 17025:2005 \\ NATIONAL RENEWABLE ENERGY LABORATORY (NREL) \\ 1617 Cole Boulevard, MS: 730 \\ Golden, CO 80401-3393 \\ Allan Roberts Phone: 3032753227
}

\section{CALIBRATION}

Valid Tn: Novemher 30,2010

Certificate Number: 2236.01

In recognition of the successful completion of the A2LA evaluation process, accreditation is granted to this laboratory to perform the following calibrations ${ }^{1}$ :

I. Optical Quantities

\begin{tabular}{|c|c|c|c|}
\hline Parameter/Equipment & Range & Best Uncertainty ${ }^{2,3}( \pm)$ & Comments \\
\hline $\begin{array}{l}\text { Primary Photovoltaic } \\
\text { Reference Cells - }\end{array}$ & & & ASTM E1125 with: \\
\hline DC Current & $(0.1$ to 200$) \mathrm{mA}$ & $0.91 \%$ & $\begin{array}{l}\text { Agilent } 34401 \text {, } \\
\text { precision resistor }\end{array}$ \\
\hline $\begin{array}{l}\text { Photovoltaic Reference } \\
\text { Cells - }\end{array}$ & & & $\begin{array}{l}\text { ASTM E948, IEC } \\
60904-1 \text { (Sec. 4) with: }\end{array}$ \\
\hline DC Voltage & $(0.1$ to 40$) \mathrm{V}$ & $0.7 \%$ & Agilent 34401 \\
\hline DC Current & $1 \mathrm{~mA}$ to $15 \mathrm{~A}$ & $1.4 \%$ & $\begin{array}{l}\text { Agilent } 34401 \text {, } \\
\text { precision resistor }\end{array}$ \\
\hline Power & $1 \mathrm{~mW}$ to $600 \mathrm{~W}$ & $1.4 \%$ & Agilent 34401 \\
\hline Area & $\begin{array}{l}(0.5 \times 0.5) \mathrm{cm} \text { to } \\
(20 \times 20) \mathrm{cm}\end{array}$ & $1.2 \%$ & $\mathrm{X}-\mathrm{Y}$ stage or caliper \\
\hline
\end{tabular}

(A2LA Cert. No. 2236.01) 11/19/2008

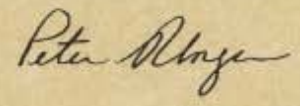

Page 1 of 2

5301 Buckeystown Pike, Suite 350 • Frederick, MD 21704-8373 • Phone: 301-644-3248 • Fax: 301-662-2974 


\begin{tabular}{|c|c|c|c|}
\hline Parameter/Equipment & Range & Best Uncertainty ${ }^{2,3}( \pm)$ & Comments \\
\hline $\begin{array}{l}\text { Photovoltaic Reference } \\
\text { Modules - }\end{array}$ & & & $\begin{array}{l}\text { ASTM E1036, IEC } \\
\text { 60904-I (Sec. 4) with: }\end{array}$ \\
\hline DC Voltage & $(0.4$ to 290$) \mathrm{V}$ & $1.6 \%$ & Agilent 34401 \\
\hline DC Current & $\begin{array}{l}(0.1 \text { to } 50) A \\
\quad A \leq(30 \times 30) \mathrm{cm} \\
A>(30 \times 30) \mathrm{cm}\end{array}$ & $\begin{array}{l}1.4 \% \\
3.5 \%\end{array}$ & $\begin{array}{l}\text { Agilent } 34401 \text {, } \\
\text { precision resistor }\end{array}$ \\
\hline Power & $\begin{aligned} 50 \mathrm{~mW} \text { to } 1200 \mathrm{~W} & \\
A & \leq(30 \times 30) \mathrm{cm} \\
A & >(30 \times 30) \mathrm{cm}\end{aligned}$ & $\begin{array}{l}2.0 \% \\
3.9 \%\end{array}$ & Agilent 34401 \\
\hline Area & $\begin{array}{l}(1 \times 1) \mathrm{cm} \text { to } \\
(150 \times 120) \mathrm{cm}\end{array}$ & $0.63 \%$ & $\begin{array}{l}\text { Microscope and tape } \\
\text { measure }\end{array}$ \\
\hline
\end{tabular}

'This laboratory is not available for commercial calibration service.

2 "Best Uncertainty" is the smallest uncertainty of measurement that a laboratory can achieve within its scope of accreditation when performing more or less routine calibrations of nearly ideal measurement standards of nearly ideal measuring equipment. Best uncertainties represent expanded uncertainties expressed at approximately the $95 \%$ level of confidence, usually using a coverage factor of $k=2$. The best uncertainty of a specific calibration performed by the laboratory may be greater than the best uncertainty due to the behavior of the customer's device and to influences from the circumstances of the specific calibration.

${ }^{3}$ In the statement of best uncertainty, percentages are percentage of reading, unless otherwise indicated. 


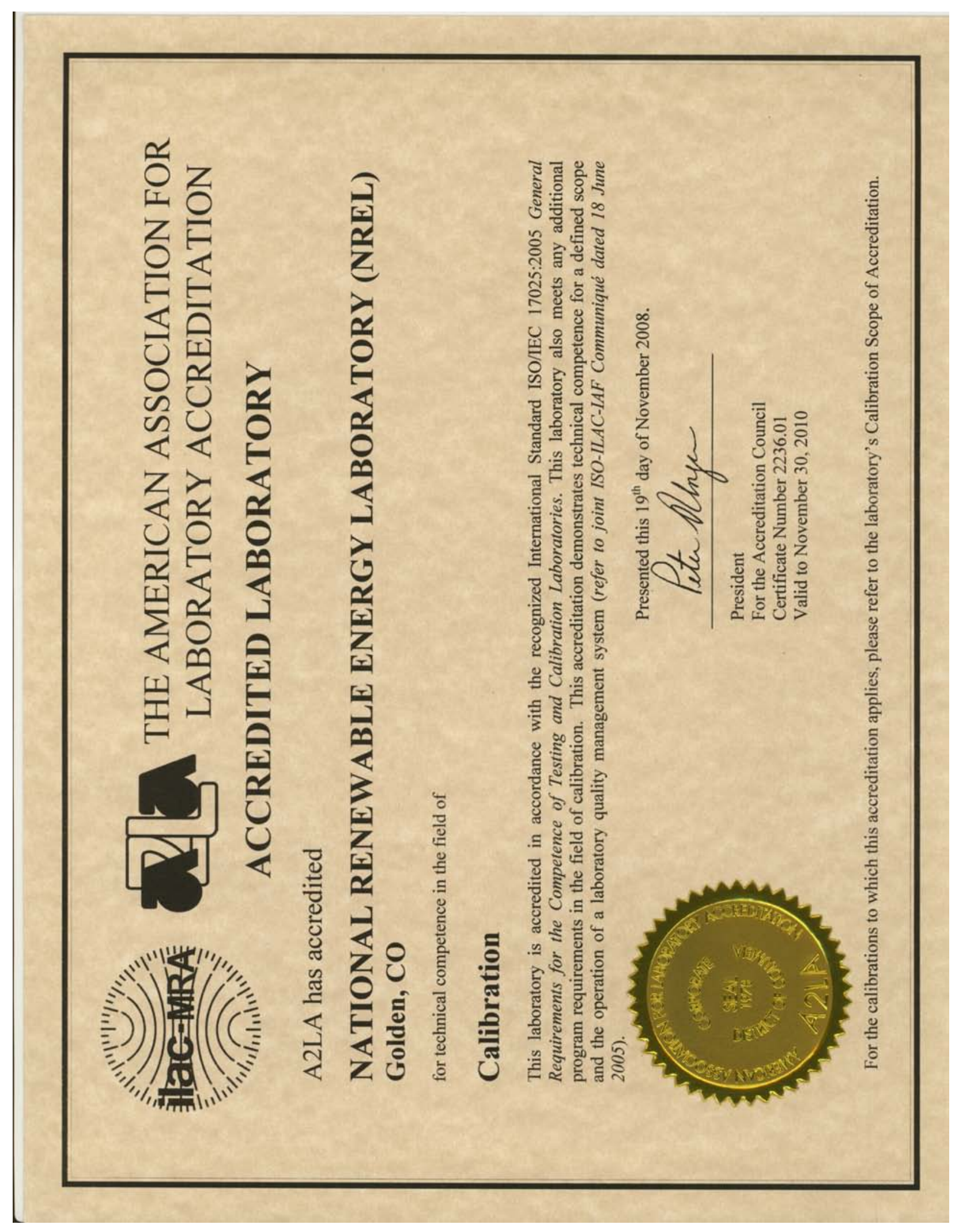




\section{APPENDIX 2}

Figure 19 below describes the operational amplifier circuit used to maintain the reference cell within $1 \mathrm{mV}$ of $0 \mathrm{~V}$. The bias box senses the voltage $V_{\text {in }}$ remotely and measures the current $I_{\text {in }}$ across a precision $10-\mathrm{ohm}$ shunt resistor $(0.02 \%)$.

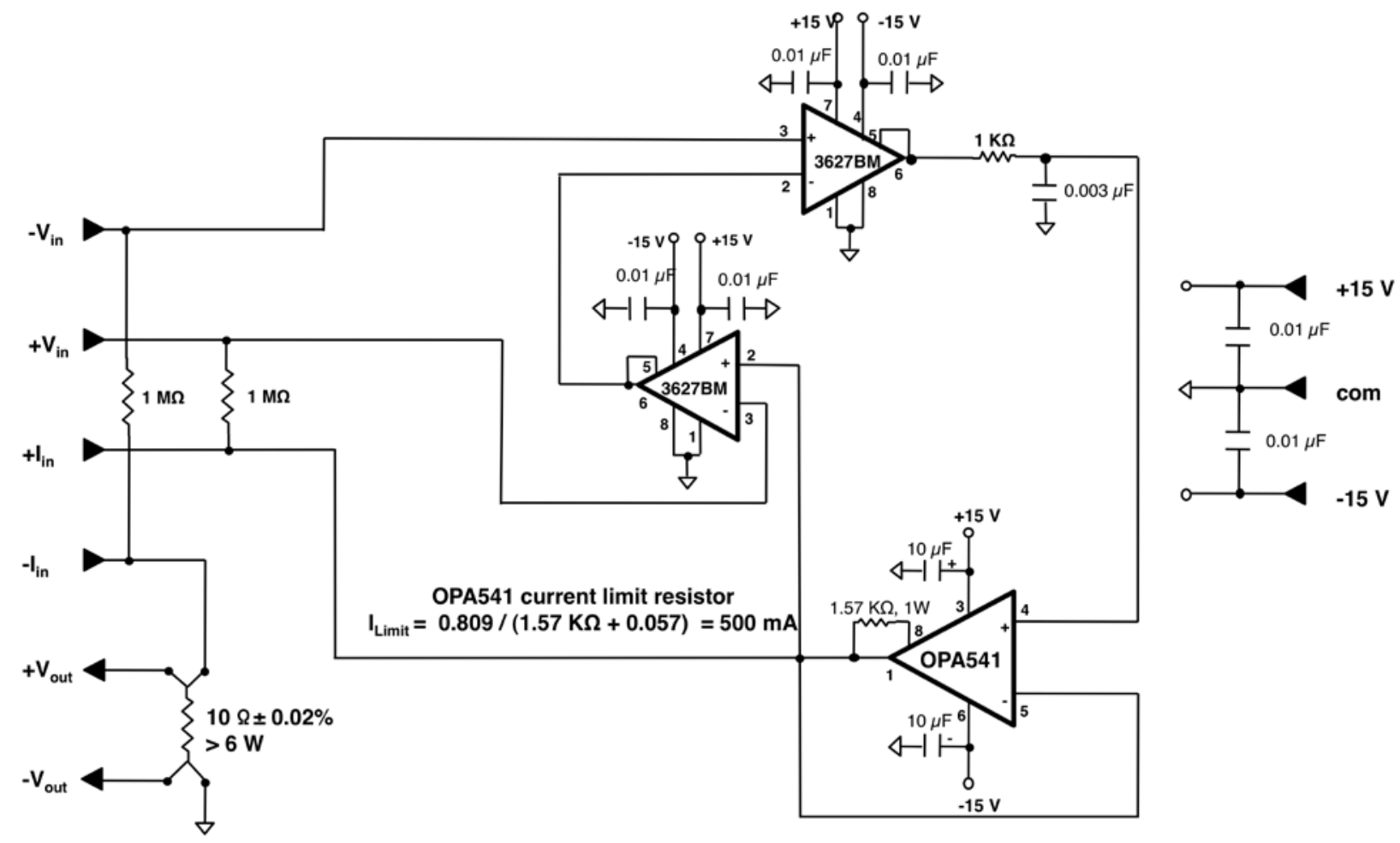

Figure 19. Schematic diagram of bias box. 


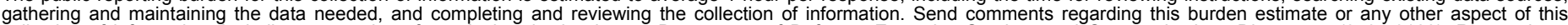

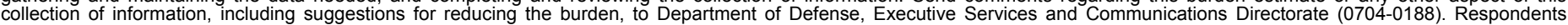

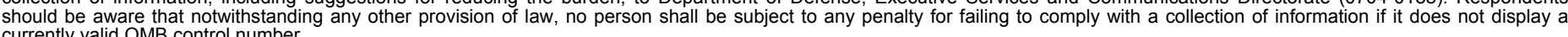

PLEASE DO NOT RETURN YOUR FORM TO THE ABOVE ORGANIZATION.
1. REPORT DATE (DD-MM-YYYY) August 2009
4. TITLE AND SUBTITLE
Uncertainty Analysis of Certified Photovoltaic Measurements at the National Renewable Energy Laboratory

3. DATES COVERED (From - To)

5a. CONTRACT NUMBER

DE-AC36-08-GO28308

5b. GRANT NUMBER

5c. PROGRAM ELEMENT NUMBER

5d. PROJECT NUMBER

NREL/TP-520-45299

5e. TASK NUMBER

PVA93420

5f. WORK UNIT NUMBER
7. PERFORMING ORGANIZATION NAME(S) AND ADDRESS(ES)

National Renewable Energy Laboratory

1617 Cole Blvd.

Golden, CO 80401-3393

\section{PERFORMING ORGANIZATION REPORT NUMBER \\ NREL/TP-520-45299}

9. SPONSORING/MONITORING AGENCY NAME(S) AND ADDRESS(ES)

\section{SPONSOR/MONITOR'S ACRONYM(S)} NREL

11. SPONSORING/MONITORING AGENCY REPORT NUMBER

12. DISTRIBUTION AVAILABILITY STATEMENT

National Technical Information Service

U.S. Department of Commerce

5285 Port Royal Road

Springfield, VA 22161

13. SUPPLEMENTARY NOTES

14. ABSTRACT (Maximum 200 Words)

The measurement of the photovoltaic $(\mathrm{PV})$ performance with respect to reference conditions requires measuring the current versus voltage with respect to a given tabular reference spectrum, junction temperature, and total irradiance. This report briefly discusses the procedures implemented by the PV Cell and Module Performance Characterization Group at the National Renewable Energy Laboratory (NREL) to achieve the lowest practical uncertainty. We present a rigorous uncertainty analysis of these procedures following the International Organization for Standardization (ISO) "Guide to the Expression of Uncertainty in Measurement." This uncertainty analysis is required for our team's laboratory accreditation under ISO standard 17025, "General Requirements for the Competence of Testing and Calibration Laboratories." Our PV cell and module performance laboratory was certified by the American Association for Laboratory Accreditation (A2LA) to perform ISO 17025-accredited calibrations on September 14, 2004.

15. SUBJECT TERMS

PV; performance; measurement; module; uncertainty analysis; ISO standard 17025;

\begin{tabular}{|c|c|c|c|c|}
\hline \multicolumn{3}{|c|}{ 16. SECURITY CLASSIFICATION OF: } & \multirow{2}{*}{$\begin{array}{l}\text { 17. LIMITATION } \\
\text { OF ABSTRACT } \\
\text { UL }\end{array}$} & \multirow{2}{*}{$\begin{array}{l}\text { 18. } \\
\text { NUMBER PAGES }\end{array}$} \\
\hline $\begin{array}{l}\text { a. REPORT } \\
\text { Unclassified }\end{array}$ & $\begin{array}{l}\text { b. ABSTRACT } \\
\text { Unclassified }\end{array}$ & $\begin{array}{l}\text { c. THIS PAGE } \\
\text { Unclassified }\end{array}$ & & \\
\hline
\end{tabular}

19a. NAME OF RESPONSIBLE PERSON
19b. TELEPHONE NUMBER (Include area code)

